\title{
Carbones and Carbon Atom as Ligands in Transition Metal Complexes
}

\author{
Lili Zhao ${ }^{1} \mathbb{1}$, Chaoqun Chai ${ }^{1}$, Wolfgang Petz ${ }^{2, *}$ and Gernot Frenking ${ }^{1,2, *}$ \\ 1 Institute of Advanced Synthesis, School of Chemistry and Molecular Engineering, Jiangsu National \\ Synergetic Innovation Center for Advanced Materials, Nanjing Tech University, Nanjing 211816, China; \\ ias_llzhao@njtech.edu.cn (L.Z.); 201861205094@njtech.edu.cn (C.C.) \\ 2 Fachbereich Chemie, Philipps-Universität Marburg, Hans-Meerwein-Strasse 4, D-35043 Marburg, Germany \\ * Correspondence: petz@chemie.uni-marburg.de (W.P.); frenking@chemie.uni-marburg.de (G.F.)
}

Academic Editors: Yves Canac and Carlo Santini

Received: 23 August 2020; Accepted: 15 October 2020; Published: 26 October 2020

check for updates

\begin{abstract}
This review summarizes experimental and theoretical studies of transition metal complexes with two types of novel metal-carbon bonds. One type features complexes with carbones $\mathrm{CL}_{2}$ as ligands, where the carbon $(0)$ atom has two electron lone pairs which engage in double $(\sigma$ and $\pi$ ) donation to the metal atom $[M] \leftleftarrows C L_{2}$. The second part of this review reports complexes which have a neutral carbon atom $C$ as ligand. Carbido complexes with naked carbon atoms may be considered as endpoint of the series $[\mathrm{M}]-\mathrm{CR}_{3} \rightarrow[\mathrm{M}]-\mathrm{CR}_{2} \rightarrow[\mathrm{M}]-\mathrm{CR} \rightarrow[\mathrm{M}]-\mathrm{C}$. This review includes some work on uranium and cerium complexes, but it does not present a complete coverage of actinide and lanthanide complexes with carbone or carbide ligands.
\end{abstract}

Keywords: carbone complexes; carbido complexes; transition metal complexes; chemical bonding

\section{Introduction}

Transition metal compounds with metal-carbon bonds are the backbone of organometallic chemistry. Molecules with M-C single bonds are already known since 1849 when Frankland reported the accidental synthesis of diethyl zinc while attempting to prepare free ethyl radicals [1,2]. Molecules with a $[\mathrm{M}]=\mathrm{CR}_{2}$ double bond (carbene complexes) or a $[\mathrm{M}] \equiv C R$ triple bond (carbyne complexes) were synthesized much later [3-6]. Two types of compounds with metal-carbon double or triple bonds having different types of bonds are generally distinguished, which are named after the people who isolated them first. Fischer-type carbene and carbyne complexes are best described in terms of dative bonds following the Dewar-Chatt-Duncan (DCD) model $[7,8][\mathrm{M}] \rightleftarrows \mathrm{CR}_{2}$ and $\left[\mathrm{M}^{(-)}\right] \rightleftarrows \mathrm{CR}^{(+)}$, whereas Schrock-type alkylidenes and alkylidynes are assumed to have electron-sharing double and triple bonds $[\mathrm{M}]=\mathrm{CR}_{2}$ and $[\mathrm{M}] \equiv \mathrm{CR}[9-11]$.

This review deals with transition metal complexes with metal-carbon bonds to two types of ligands, which have only recently been isolated and theoretically studied. One type of ligand are carbones $\mathrm{CL}_{2}$ [12], which are carbon(0) compounds with two dative bonds to a carbon atom in the excited ${ }^{1} \mathrm{D}$ state $\mathrm{L} \rightarrow \underline{\mathrm{C}} \leftarrow \mathrm{L}$ where the carbon atom retains its four valence electrons as two lone pairs that can serve as four-electron donors $[13,14]$. Thus, carbones $\mathrm{CL}_{2}$ are four-electron donor ligands whereas carbenes $C_{2}$ are two-electron donors. Carbenes have a formally [15] vacant $p(\pi)$ orbital that can accept electrons in donor-acceptor complexes $\mathrm{M} \rightleftarrows \mathrm{CR}_{2}$ whereas carbones are double $(\sigma$ and $\pi$ ) donors in complexes $[\mathrm{M}] \rightleftarrows \mathrm{CL}_{2}$. A good Lewis acid acceptor fragment $\mathrm{A}$ for a carbene complex has a vacant $\sigma$ orbital and an occupied $\pi$ orbital whereas a suitable acceptor for a carbone is a double Lewis acid with vacant $\sigma$ and $\pi$ orbitals as shown in Figure 1a,b. If the Lewis acid A has an occupied $\pi$ orbital, it would lead to $\pi$ repulsion with the $\pi$ lone pair of the carbone $\mathrm{CL}_{2}$, whereby the repulsive interaction is reduced if $\mathrm{L}$ is a good $\pi$ acceptor (Figure 1c). The two electron lone pairs of a carbone may bind 
to one or two monodentate Lewis acids A or protons or to a single bidentate Lewis acid as shown in Figure 1. The large second proton affinity is a characteristic feature of carbones, which distinguishes them from carbenes [16]. Examples of all cases are known and are described below.

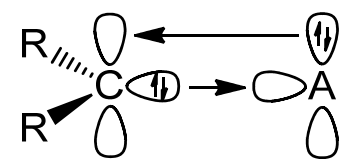

(a)

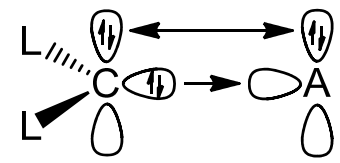

(c)

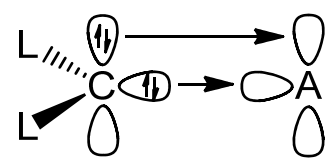

(b)

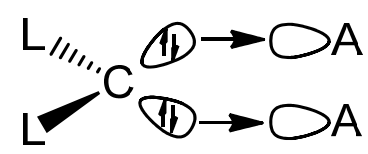

(d)

Figure 1. Schematic representation of the most important orbital interactions between carbene ligands $\mathrm{CR}_{2}$ and carbones $\mathrm{CL}_{2}$ with Lewis acids A.(a) Carbene complex with a monodentate Lewis acid; (b) Carbone with a bidentate Lewis acid; (c) Carbone with a monodentate Lewis acid; (d) Carbone with two monodentate Lewis acids.

It is important to realize that the two electron lone-pairs of a carbone $\mathrm{CL}_{2}$ may additionally engage in $\pi$-backdonation to the ligands $L$ whose strength depends on the availability of vacant $\pi$ orbitals of the ligands L. Stronger $\pi$ acceptor ligands $L$ enhance the $\pi$-backdonation $L \leftarrow \bar{C} \rightarrow L$ which leads to wider bending angles at the carbon atom (Figure 2). The significant bending of free $\mathrm{C}(\mathrm{CO})_{2}[17,18]$ can straightforwardly be explained in terms of dative bonding in carbon suboxide $\mathrm{C}_{3} \mathrm{O}_{2}[19,20]$. The $\pi$-acceptor strength of ligands $\mathrm{L}$ thus modulates the donor interaction of the carbone $\mathrm{CL}_{2}$.<smiles>C1=CC2CC1[PbH](c1ccccc1)C2(c1ccccc1)c1ccccc1</smiles>
$\left(131.7^{\circ}\right)$

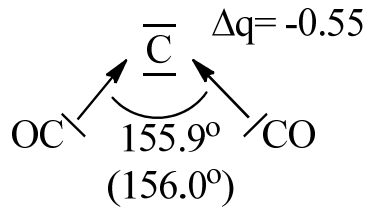

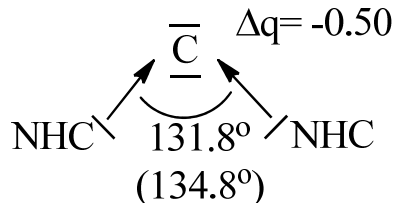
$\left(134.8^{\circ}\right)$

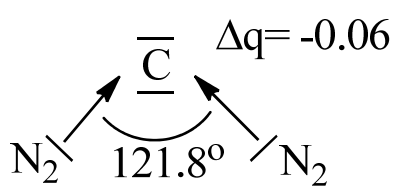

Figure 2. Calculated and (in parentheses) experimental bond angles of carbones $\mathrm{CL}_{2}$ with different ligands $\mathrm{L}$ and partial charges $\Delta \mathrm{q}$ of the divalent carbon atom. The data are taken from [19].

The following list gives some essential features of carbones and their differences to carbenes. At the same time we want to stress that the distinction between carbenes and carbones are just a useful classification of compounds, which are a helpful model to explain the structures and reactivity of molecules. Nature does not exhibit a strict distinction line and there are complexes with electronic structures that have intermediate features between both classes of compounds. Carbenes and carbones are two ordering principles like ionic and covalent bonding. Intermediate cases are common and yet, the two concepts are essential ingredients of chemistry. The first part of this review summarizes experimental and theoretical work about transition metal complexes with carbone ligands $[\mathrm{M}]-\mathrm{CL}_{2}$.

1. Carbones are neutral carbon(0) compounds of the general formula $\mathrm{CL}_{2}$, which possess two electron lone pairs of electrons of $\sigma$ and $\pi$ symmetry, respectively.

2. Carbones $\mathrm{CL}_{2}$ have dative $\sigma$ bonds $\mathrm{L} \rightarrow \underline{\mathrm{C}} \leftarrow \mathrm{L}$ and weaker $\pi$ backdonation $\mathrm{L} \leftarrow \underline{\overline{\mathrm{C}}} \rightarrow \mathrm{L}$ which resemble donor-acceptor bonds in transition metal complexes. 
3. The carbon atom of carbones has very large electron densities and thus, unusually large negative partial charges.

4. In contrast to carbenes, carbones exhibit high first and second proton affinities (PAs) in the region of about 290 and $150-190 \mathrm{kcal} / \mathrm{mol}$, respectively. The second PA is a sensitive probe for the divalent $\mathrm{C}(0)$ character of a $\mathrm{CL}_{2}$ molecule. Carbones can take up one and two protons with formation of $\left[\mathrm{HCL}_{2}\right]^{+}$cations or $\left[\mathrm{H}_{2} \mathrm{CL}_{2}\right]^{2+}$ dications, respectively.

5. Carbones have a bent equilibrium geometry where the bending angle becomes wider when the ligand $\mathrm{L}$ is a better $\pi$ acceptor.

6. Carbones can take up one or two monodentate Lewis acids $A$ building the complexes $A \leftarrow C\left(L_{2}\right)$ and $\mathrm{A} \leftarrow \mathrm{C}\left(\mathrm{L}_{2}\right) \rightarrow \mathrm{A}$ or one bidentate Lewis acid $\mathrm{A} \leftleftarrows \mathrm{C}\left(\mathrm{L}_{2}\right)$.

To the thematic of carbones several review articles were reported previously; A general overview on species that bear two lone pairs of electrons at the same C-center are summarized in [21], transition metal adducts of carbones are described in [22], and those of main group fragments in [23]. Two contributions, [24] and [25], in the series Structure and Bonding (Springer Edition) also deal with carbone transition metal addition compounds.

The second type of transition metal complexes with a carbon ligand features species with a naked neutral carbon atom as a ligand $[\mathrm{M}]-\mathrm{C}$, which can be considered as endpoint of the series $[\mathrm{M}]-\mathrm{CR}_{3} \rightarrow[\mathrm{M}]-\mathrm{CR}_{2} \rightarrow[\mathrm{M}]-\mathrm{CR} \rightarrow[\mathrm{M}]-\mathrm{C}$. Complexes with negatively charged carbon ligands $[\mathrm{M}]-\mathrm{C}^{--}$, which are isoelectronic to nitride complexes [M]-N and are termed as carbides, were synthesized in 1997 by Cummins [26]. The first neutral carbon complex [M]-C, which was prepared and structurally characterized was reported in 2002 by by Heppert and co-workers [27]. They isolated the diamagnetic 16 valence electron ruthenium complexes $\left[\left(\mathrm{PCy}_{3}\right) \mathrm{LCl}_{2} \mathrm{Ru}(\mathrm{C})\right](\mathrm{L}=\mathrm{PCy}$ and 1,3-dimesityl-4,5-dihydroimidazol-2-ylidene; $\mathrm{Cy}=\mathrm{Cyclohexyl)}$ by a metathesis facilitated reaction. Quantum chemical calculations of model compounds suggested that the Ru-C bond in the complexes is best described by an electron-sharing double bond like in Schrock carbenes, which is reinforced

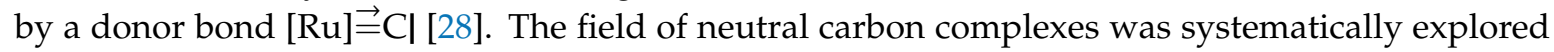
in recent years by Bendix [29]. This review summarizes in its second part the research in transition metal complexes with a naked carbon atom as ligand [M]-C that has been accomplished since 2002 . The review includes some work on uranium and cerium complexes, but it does not present a complete coverage of actinide and lanthanide complexes with carbone or carbide ligands.

\section{Transition Metal Complexes with Carbone Ligands $[\mathrm{M}]-\mathrm{CL}_{2}$}

\subsection{Transition Metal Addition Compounds of Symmetrical Carbones $C\left(P R_{3}\right)_{2}$}

Among the existing carbones with a symmetric P-C-P skeleton, five species (1a-1e) are known today as donor ligands to various transition metal fragments as outlined in Figure 3. From other linear or bent carbones with this skeleton, no transition metal complexes are described so far.

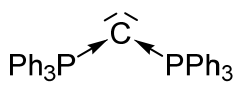

$1 a$

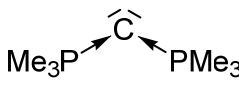

$1 c$

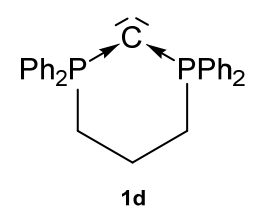

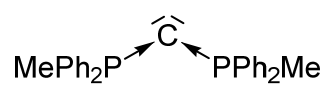

$1 b$



Figure 3. Symmetric carbones 1a-1e as ligands for transition metal complexes. 
In 1961, 1a was detected by Ramirez [30], and 1b-1d stem from the laboratory of Schmidbaurs group [31]. Later on, a series of related carbones were synthesized, but for which transition metal complexes are unknown so far. Quite recently the new amino substituted carbone 1e was published together with $\mathrm{Zn}$ and $\mathrm{Rh}$ addition compounds (See Scheme 1) [32]. In the 31P NMR spectra singlets at about -4.50 (1a), -6.70 (1b), -29.6 (1c), -22.45 (1d), and 12.5 ppm (1e) confirm the symmetric array of the compounds. All carbones have a bent structure but a linear form of $1 \mathbf{a}$ is realized if crystallized from benzene [33,34]. 1a has a short P-C distance of 1.633(4) $\AA$ and the P-C-P angle amounts to $130.1(6)^{\circ}$ [35]. The carbone $\mathbf{1 b}$ exhibits a slightly longer P-C distance of 1.648(4) $\AA$ and the introduction of two less bulky methyl groups allows a more acute P-C-P angle of 121.8(3) ${ }^{\circ}$ [36]. 1d has similar P-C bond distances of 1.645(12) $\AA$ 1.653(14) $\AA$ and the acutest P-C-P angle in this series of $116.7(7)^{\circ}[37,38]$. For 1c, gas phase electron diffraction studies result in a P-C distance of 1.594(3) $\AA$ and a P-C-P angle of $147.6(5)^{\circ}$ assuming an apparent non-linearity but linearity in the average structure [37]. All structural parameters of $\mathbf{1 e}$ are close to those of $\mathbf{1 a}\left(\mathrm{P}-\mathrm{C}=1.632(2) \AA\right.$, $\mathrm{P}-\mathrm{C}-\mathrm{P}$ angle $=136.5(3)^{\circ}[32]$.

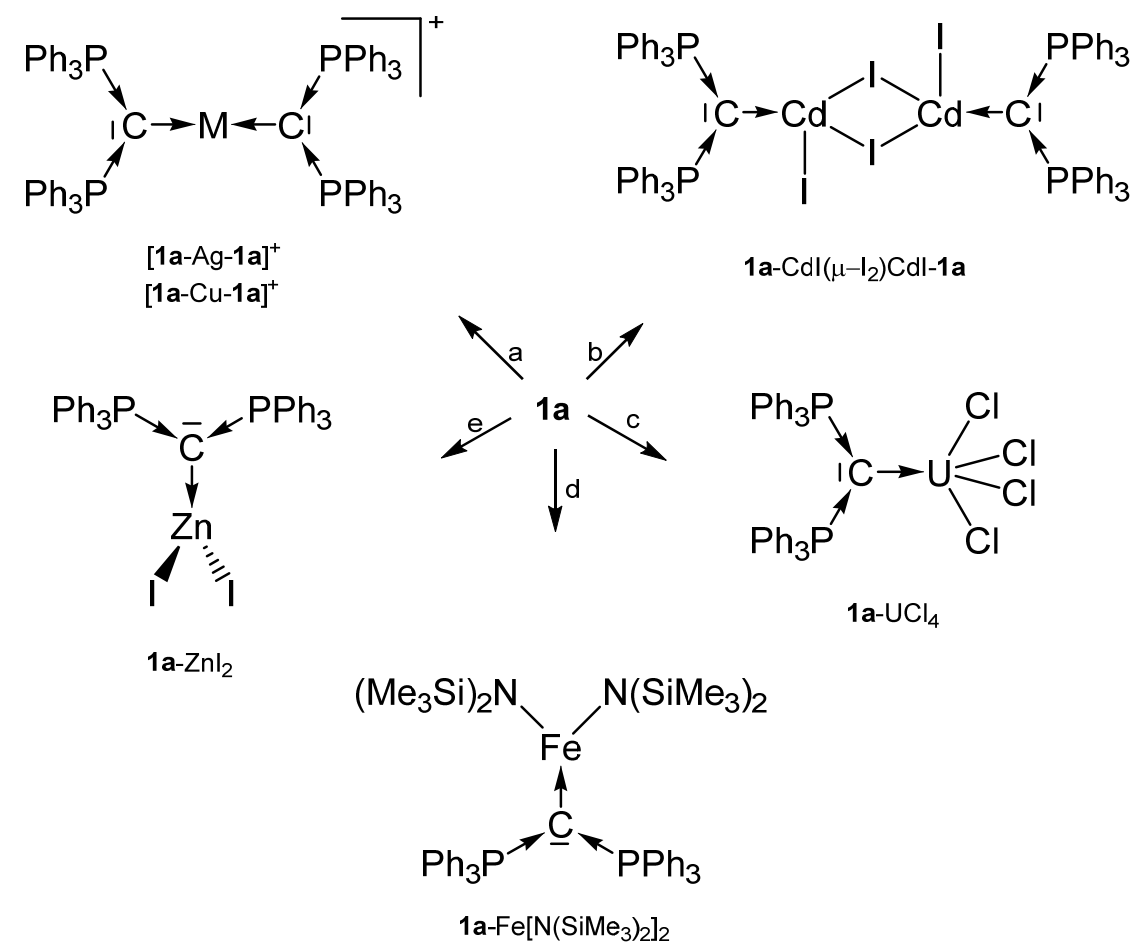

Scheme 1. Selected transition metal compounds with the carbone 1a as two electron donor ligand; (a) $\mathrm{MI},(\mathbf{b}) \mathrm{CdI}_{2}$, (c) $\mathrm{UCl}_{4}$, (d) $\mathrm{Fe}\left(\mathrm{N}\left\{\mathrm{SiMe}_{3}\right\}_{2}\right)_{2},\left(\right.$ e) $\mathrm{ZnI}_{2}$.

In Table 1, transition metal addition compounds between carbones with the P-C-P core are collected. All compounds show longer P-C bonds than the basic carbones as consequence of the competition of the occupied p orbital at $\mathrm{C}(0)$ between the two $\mathrm{P}-\sigma^{*}$ orbitals and those of $\mathrm{A}$.

Table 1. Transition metal complexes with the carbones 1a to 1e including C-M and P-C bond lengths and P-C-P angles and ${ }^{31}$ PNMR shifts in ppm.

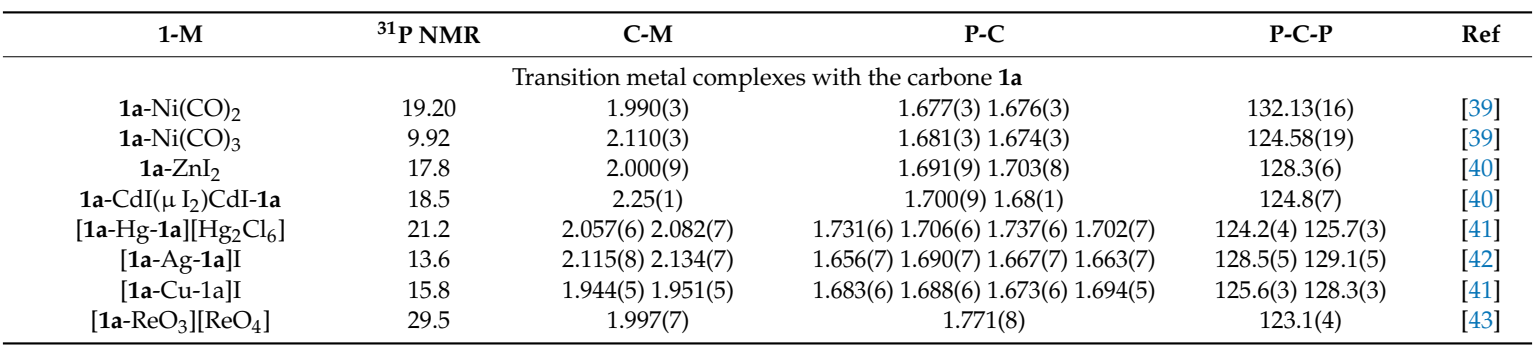


Table 1. Cont.

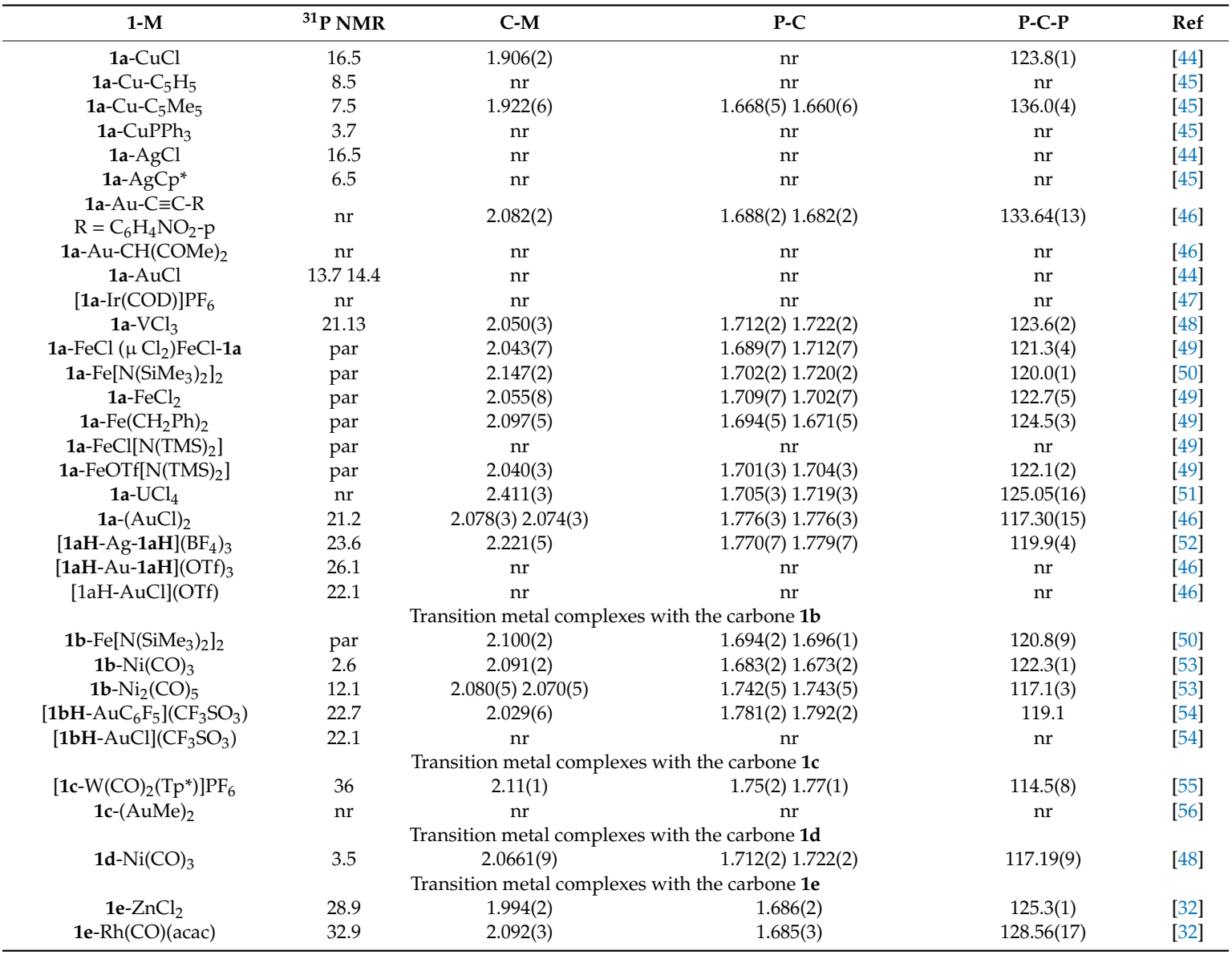

Occupied d orbitals of $\mathrm{Ni}$ in the $1 \mathrm{a}-\mathrm{Ni}(\mathrm{CO})_{3}$ complex elongate the $\mathrm{C}-\mathrm{Ni}$ bond to a carbone (2.110 $\AA$ [ [39] but this leads to a relative short bond length to a NHC (1.971 $\AA$ ) moiety [57]. In contrast, $\mathrm{UCl}_{4}$ leads to a short bond to a carbone (2.411 $\AA$ ) [51] indicating an appreciable U-C double bond character and a long one to a NHC base $(2.612 \AA)[58,59]$.

The cation $\left[1 \mathrm{a}-\mathrm{ReO}_{3}\right]^{+}$holds the longest one with 1.771(8) $\AA$ indicating an appreciable $\mathrm{C}=\mathrm{Re}$ double bond character. This feature applies also in part to $1 \mathrm{a}-\mathrm{UCl}_{4}$ and $1 \mathrm{c}-\mathrm{W}(\mathrm{CO})_{2} \mathrm{~N}_{3}$ with elongated $\mathrm{P}-\mathrm{C}$ bonds(See Scheme 2); a partial C-U double bond is confirmed by theoretical calculations. Similar long P-C bonds are found in the trication $[\mathbf{1 a H}-\mathrm{Ag}-\mathbf{1 a H}]^{3+}$, in $\mathbf{1 a}-(\mathrm{AuCl})_{2}(\mathrm{See}$ Scheme 3), and in $\mathbf{1 b}-\mathrm{Ni}_{2}(\mathrm{CO})_{5}($ See Scheme 4$)$, where the carbone provides each two electrons to two accepting Lewis acids as depicted in Figure 1d.
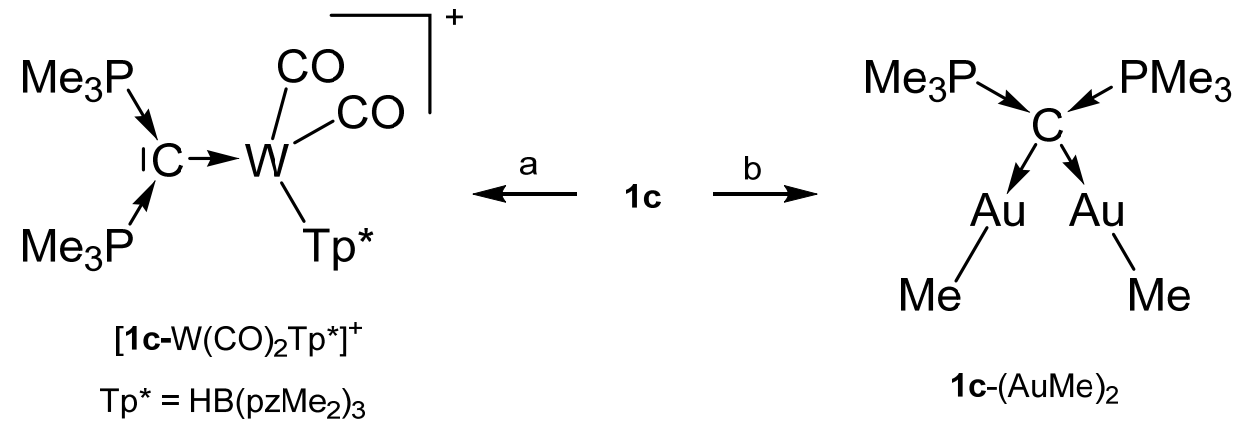

Scheme 2. Transition metal complex with the carbone $1 \mathrm{c}$ as two and four electron donor ligand.

(a) $\left[\mathrm{Tp}^{*}(\mathrm{CO})_{2} \mathrm{~W} \equiv \mathrm{CPMe}_{3}\right]^{+} / \mathrm{PMe}_{3},(\mathbf{b}) 1 \mathrm{c} / 2 \mathrm{MeAuPMe}_{3}$. 


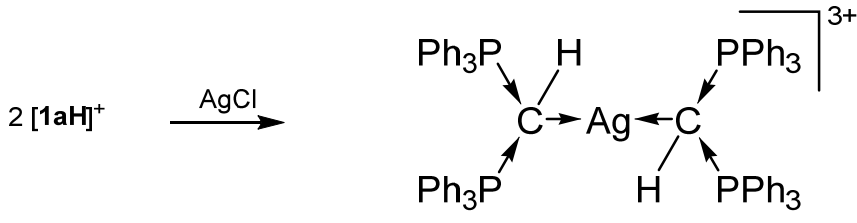

$[1 \mathrm{aH}-\mathrm{Ag}-1 \mathrm{aH}]^{3+}$

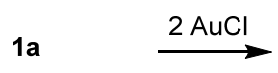

$1 \mathrm{a}-(\mathrm{AuCl})_{2}$

Scheme 3. Selected transition metal compounds with the carbone 1a as four electron donor ligand.<smiles>[X][Al]C(P)C(P)P(C)P</smiles>

$[1 \mathrm{bH}-\mathrm{AuX}]^{+}, \mathrm{X}=\mathrm{Cl}, \mathrm{C}_{6} \mathrm{~F}_{5}$

\section{$[1 \mathrm{bH}]^{+}$}

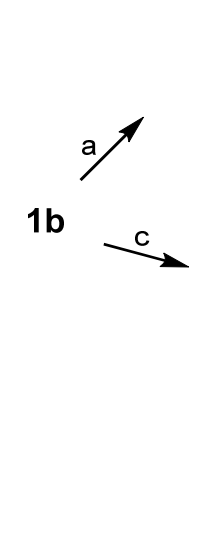

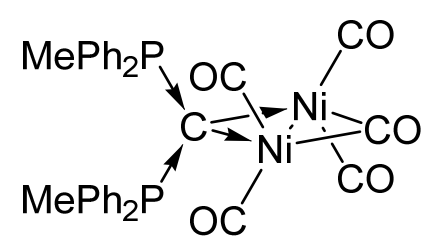

$\mathbf{1 b}-\mathrm{Ni}_{2}(\mathrm{CO})_{5}$

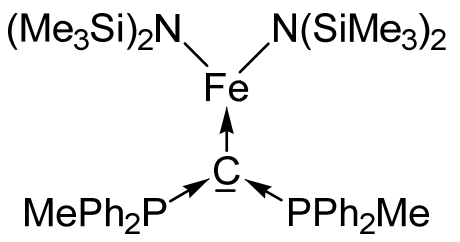

$1 \mathrm{~b}-\mathrm{Fe}\left[\mathrm{N}\left(\mathrm{SiMe}_{3}\right)_{2}\right]_{2}$

Scheme 4. Selected transition metal complexes with the carbone $\mathbf{1 b}$ as two and four electron donor ligand. (a) $\mathrm{Ni}(\mathrm{CO})_{4}$, (b) $\mathrm{Ni}(\mathrm{CO})_{4}$ under $\mathrm{CO}$ atm, (c) $\mathrm{Fe}\left(\mathrm{N}\left\{\mathrm{SiMe}_{3}\right\}_{2}\right)_{2}$, (d) AuX(tht).

The P-C-P angles are in the range between $115^{\circ}$ and $132^{\circ}$ reflecting the required space of the appropriate Lewis acid. The ${ }^{31} \mathrm{P}$ NMR shift of the carbone $1 \mathrm{a}$ amounts to about $-5 \mathrm{ppm}$ and those of the related addition compounds are shifted to lower fields and range between $4 \mathrm{ppm}$ and $30 \mathrm{ppm}$. All iron(II) complexes of $\mathbf{1 a}$ and $\mathbf{1 b}$ are paramagnetic and ${ }^{31} \mathrm{P}$ NMR spectra could not be obtained.

For the ${ }^{31} \mathrm{P}$ NMR spectrum of the carbone $1 \mathbf{b}$, a shift of $-6.70 \mathrm{ppm}$ was recorded [31]. With exception of $\mathbf{1 b}-\mathrm{Ni}(\mathrm{CO})_{3}$ which resonate at $2.6 \mathrm{ppm}$, low field shifts between 12 and $22 \mathrm{ppm}$ were found when $\mathbf{1 b}$ act as a four electron donor [40].

Further, $1 \mathbf{1 e}-\mathrm{ZnCl}_{2}$ (See Scheme 5) [32] and 1a- $\mathrm{ZnI}_{2}$ [53] have closely related structural parameters but exhibit shorter C-Zn bond lengths than to related NHC-addition compounds ( $\Delta=0.051 \AA$ [60]. In both compounds a nearly perpendicular array of the $\mathrm{ZnX}_{2}$ and the PCP plane are found. No tendency for an additional $\mathrm{N}$-coordination to the amino ligand of $1 \mathbf{e}$ is recorded for the $\mathrm{ZnCl}_{2}$ addition compound. In contrast the $\mathrm{Rh}-\mathrm{C}$ distances in $\mathbf{1 e}-\mathrm{Rh}(\mathrm{CO})_{2}(\mathrm{acac})$ are longer $(\Delta=0.117 \AA)$ than in the corresponding 
NHC compound [61] and a partial $\pi$ interaction was found by DFT calculation. Rh also shows no tendency for coordination of the adjacent amino groups [32].

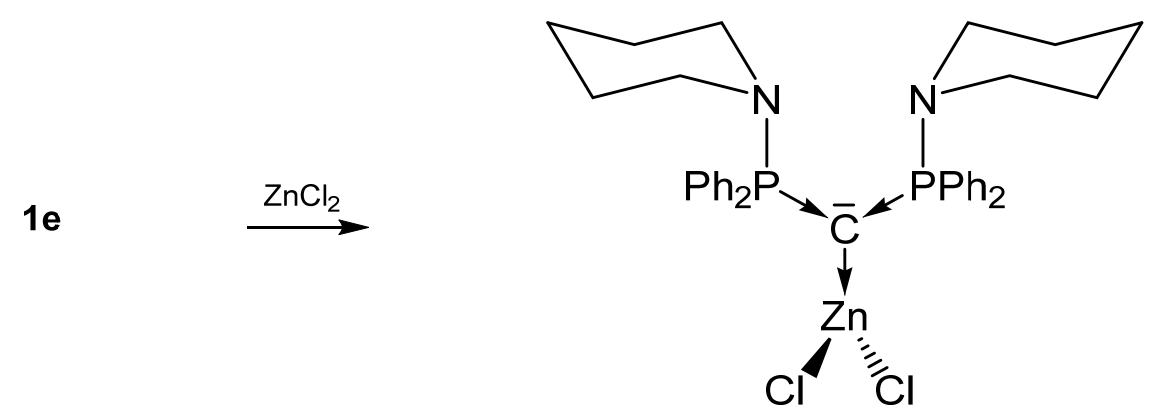

Scheme 5. Selected transition metal complex with the carbone 1e as two electron donor ligand.

\subsection{Transition Metal Addition Compounds of Carbones $C\left(P R_{3}\right)_{2}$ with an Additional Pincer Function}

Starting material for $2 \mathrm{a}$ is not the free carbone $\mathrm{Ph}_{2} \mathrm{P}-\mathrm{CH}_{2}-\mathrm{PPh}_{2}-\mathrm{C}-\mathrm{PPh}_{2}-\mathrm{CH}_{2}-\mathrm{PPh}_{2}$, which could not be prepared so far, but the dication $\left[\mathrm{Ph}_{2} \mathrm{P}-\mathrm{CH}_{2}-\mathrm{PPh}_{2}-\mathrm{CH}_{2}-\mathrm{PPh}_{2}-\mathrm{CH}_{2}-\mathrm{PPh}_{2}\right]^{2+}$ as reported by Peringer [62]. Later on, Sundermeyer studied the deprotonation of the cation $\left[\mathrm{Ph}_{2} \mathrm{P}_{-} \mathrm{CH}_{2}-\right.$ $\left.\mathrm{PPh}_{2}-\mathrm{CH}-\mathrm{PPh}_{2}-\mathrm{CH}_{2}-\mathrm{PPh}_{2}\right]^{+}$by quantum chemical methods giving more or less stable tautomers of 2a, see Figure 4. Deprotonation of the tautomer $C$ of $2 \mathbf{a}$ generates the anionic pincer ligand $\left[\mathrm{Ph}_{2} \mathrm{P}-\mathrm{CH}-\mathrm{PPh}_{2}-\mathrm{CH}-\mathrm{PPh}_{2}-\mathrm{CH}-\mathrm{PPh}_{2}\right]^{-}[2 \mathrm{c}]^{-}$[63]. The same working group also published the X-ray structure of the pincer ligand $\mathbf{2} \mathbf{b}$ with the P-C-P angle of $133.76(13)^{\circ}$ and P-C distances of 1.633(2) and 1.642(2) $\AA$; the ${ }^{31} \mathrm{P}$ NMR shift $\delta=-5.6$ ppm [64].

Various cationic complexes where reported with the pincer ligand 2a (See Figure 4) and group 10 metal halides and one dication with the group 11 metal Au. The ${ }^{31} \mathrm{P}$ NMR shifts range between 32 and $41 \mathrm{ppm}($ See Table 2). As with $\mathbf{1 a}$ the carbone carbon atom of $\mathbf{2} \mathbf{a}$ is basic enough to accept a proton to generate complexes of the type $2 \mathrm{aH}-\mathrm{MCl}$ dications with all group 10 elements (See Scheme 6).<smiles>c1ccc(C(PCP(c2ccccc2)C(c2ccccc2)P(c2ccccc2)c2ccccc2)P(c2ccccc2)c2ccccc2)cc1</smiles><smiles>C=CC</smiles><smiles>C(=CP(c1ccccc1)C(Pc1ccccc1)c1ccccc1)c1ccccc1</smiles><smiles>c1ccc(C(P(c2ccccc2)c2ccccc2)P(c2ccccc2)c2ccccc2)cc1</smiles>

2a<smiles>C(=Pc1ccccn1)P(c1ccccc1)c1ccccc1</smiles>

2b<smiles>CCCC(Pc1ccccc1)P(PCc1ccccc1)c1ccccc1</smiles>

Figure 4. Tripodal basic pincer ligand $2 \mathrm{a}$ with its tautomers, the anionic pincer ligand $2 \mathrm{cH}^{-}$and the pyridyl pincer ligand $\mathbf{2 b}$. 
Table 2. Transition metal complexes with the phosphine based pincer ligands $2 \mathbf{a}$ and the pyridyl based pincer ligand $2 b$; C-M and P-C distances are included and ${ }^{31} \mathrm{P}$ NMR shifts in ppm.

\begin{tabular}{|c|c|c|c|c|c|}
\hline & ${ }^{31}$ P NMR & C-M & P-C & P-C-P & Ref \\
\hline \multicolumn{6}{|c|}{ Transition metal complexes with the tripodal carbone $\mathbf{2 a}$} \\
\hline$[2 \mathbf{a}-(\mathrm{PdCl})] \mathrm{Cl}$ & 34.5 & $2.062(2)$ & $1.694(3)$ & $124.9(2)$ & {$[62,65]$} \\
\hline$[2 \mathbf{a}-(\mathrm{NiCl})] \mathrm{Cl}$ & 36.4 & $1.942(4)$ & $1.6925(18)$ & 125.1(2) & [65] \\
\hline$[2 \mathbf{a}-(\mathrm{NiCl})]_{2} \mathrm{NiCl}_{4}$ & $\mathrm{nr}$ & $1.930(7)$ & $1.696(7) 1.701(7)$ & $126.3(4)$ & [65] \\
\hline$[2 \mathrm{a}-(\mathrm{PtCl})] \mathrm{Cl}$ & 35.7 & $2.060(4)$ & $1.692(5)$ & $124.86(15)$ & [65] \\
\hline$[2 \mathbf{a}-(\mathrm{NiMe})]\left[\mathrm{AlCl}_{2} \mathrm{Me}_{2}\right]$ & 31.8 & 1.959 & 1.697 & 120.9 & [66] \\
\hline$[2 \mathrm{a}-(\mathrm{AuCl})] \mathrm{TfO}_{2}$ & $\mathrm{nr}$ & $2.080(8)$ & $1.723(8)$ & $124.5(5)$ & {$[67]$} \\
\hline$[2 \mathbf{a}-(\mathrm{AuCl})]\left(\mathrm{NO}_{3}\right)_{2}$ & 40.8 & $2.060(3)$ & $1.721(3)$ & $125.1(2)$ & [67] \\
\hline$[2 \mathbf{a}-(\mathrm{AuI})](\mathrm{TfO})_{2}$ & 41.1 & $2.082(8)$ & $1.723(8)$ & $124.9(5)$ & [67] \\
\hline$[2 \mathrm{aH}-\mathrm{PdCl}] \mathrm{Cl}_{2}$ & 42.4 & 2.102(3) & $1.803(3)$ & $121.9(2)$ & [62] \\
\hline$[2 \mathrm{aH}-\mathrm{PtCl}] \mathrm{Cl}_{2}$ & 44.4 & $2.106(4)$ & $1.811(4) 1.823(4)$ & $120.4(2)$ & [62] \\
\hline$[2 \mathrm{aH}-\mathrm{NiCl}] \mathrm{Cl}_{2}$ & 32.7 & 1.990 & $1.801-1.834$ & 121.1 & {$[65,66]$} \\
\hline$[2 \mathrm{aH}-(\mathrm{CuCl})] \mathrm{PF}_{6}$ & $\mathrm{nr}$ & $2.304(2)$ & $1.745(2)$ & $125.26(14)$ & {$[63]$} \\
\hline $2 \mathrm{a}-(\mathrm{CuCl})_{2}$ & 20.4 & 2.2041 & 1.718 & $122.86(14)$ & [63] \\
\hline $2 a-(C u I)_{2}$ & 22.5 & 2.4936 & 1.717 & $126.3(4)$ & [63] \\
\hline 2a- $(\mathrm{CuSPh})_{2}$ & $19.8-19.0$ & 2.195 & 1.712 & $126.9(7)$ & [63] \\
\hline \multicolumn{6}{|c|}{ Transition metal complexes with the tripodal carbone $\mathbf{2 b}$} \\
\hline 2b-(CeBr 3 THF $)$ & -10.2 & $2.597(6)$ & $1.672(6)$ & $122.5(4)$ & [68] \\
\hline $\mathbf{2 b}-(\mathrm{CeBr})-\mathbf{2 b}$ & $\mathrm{nr}$ & $2.573(6) 2.597(6)$ & $1.684(7)$ & $120.5(4)$ & [68] \\
\hline $2 \mathrm{~b}-\left(\mathrm{UCl}_{4}\right)$ & $\mathrm{nr}$ & $2.471(7)$ & $1.696(7)$ & $121.3(4)$ & [41] \\
\hline $\mathbf{2 b}-\left(\mathrm{TiCl}_{3}\right)[57]$ & 18.24 & $2.144(6)$ & $1.670(3) 1.670(3)$ & $129.9(4)$ & [64] \\
\hline $\mathbf{2 b}-\left(\mathrm{Cr}(\mathrm{CO})_{3}\right)$ & 6.97 & 2.212(2) & $1.651(3) 1.650(3)$ & $133.6(2)$ & [64] \\
\hline $2 \mathrm{~b}-\left(\mathrm{MnCl}_{2}\right)$ & par & $2.1843(14)$ & $1.6671(17) 1.6636(17)$ & $127.70(9)$ & [64] \\
\hline $\mathbf{2 b}-\left(\mathrm{CoCl}_{2}\right)$ & par & $2.015(6)$ & $1.680(7) 1.661(7)$ & $127.5(3)$ & [64] \\
\hline $2 \mathbf{b}-\left[\mathrm{Mo}_{2}(\mathrm{CO})_{7}\right]$ & 9.49 & $2.355(4)$ & $1.722(4) 1.724(4)$ & $120.4(2)$ & [64] \\
\hline$[2 \mathbf{b}-(\mathrm{PdCl})] \mathrm{Cl}$ & 31.6 & 2.004(4) & $1.689(4) 1.676(4)$ & 132.4 & [64] \\
\hline \multirow[t]{2}{*}{$2 \mathbf{b}-\left[\mathrm{Ni}_{2}(\mathrm{CO})_{4}\right]$} & 34.20 & $2.0635(18)$ & $1.7142(18)$ & $\mathrm{nr}$ & [64] \\
\hline & & $2.0912(18)$ & $1.7146(18)$ & & \\
\hline \multirow{2}{*}{$2 \mathbf{b}-\left(\mathrm{Cu}_{2} \mathrm{Cl}_{2}\right)$} & 21.4 & $\mathrm{nr}$ & $1.714(3)$ & $121.51(14)$ & [63] \\
\hline & & & $1.718(2)$ & & \\
\hline \multirow[t]{2}{*}{$2 \mathbf{b}-\left(\mathrm{Cu}_{2} \mathrm{I}_{2}\right)$} & 21.5 & $\mathrm{nr}$ & $1.679(5)$ & $128.5(3)$ & [63] \\
\hline & & & $1.702(5)$ & & \\
\hline \multirow[t]{2}{*}[2\mathbf{b}-\mathrm{Cu}_{2}(\mathrm{PPh}_{3})_{2}]{$\left(\mathrm{PF}_{6}\right)_{2}$} & 32.9 & $\mathrm{nr}$ & $1.709(10)$ & $126.8(6)$ & [63] \\
\hline & & & $1.693(9)$ & & \\
\hline \multirow{2}{*}{ 2b-Cu $\left.\mathrm{Cu}_{2}\left(\mathrm{PC}_{6} \mathrm{H}_{4} \mathrm{OMe}\right)_{2}\right]\left(\mathrm{PF}_{6}\right)_{2}$} & 32.8 & $\mathrm{nr}$ & $1.707(3)$ & $123.64(18)$ & [63] \\
\hline & & & $1.710(3)$ & & \\
\hline$\left[\mathbf{2} \mathbf{b}-\mathrm{Cu}_{2}(\mathrm{DPEPhos})\right]\left(\mathrm{PF}_{6}\right)_{2}$ & 29.7 & $\mathrm{nr}$ & $1.710(4)$ & $124.0(2)$ & [63] \\
\hline \multirow[t]{2}{*}[2\mathbf{b}-\mathrm{Cu}_{2}(\text{XantPhos})]{$\left(\mathrm{PF}_{6}\right)_{2}$} & 34.9 & $\mathrm{nr}$ & $1.712(4)$ & & \\
\hline & & & $1.7064(19)$ & $122.10(11)$ & [63] \\
\hline$\left[2 \mathbf{b}-\mathrm{Cu}_{2}(\mathrm{dppf})\right]\left(\mathrm{PF}_{6}\right)_{2}$ & 36.5 & $\mathrm{nr}$ & $1.7211(18)$ & & \\
\hline \multirow{3}{*}{$2 \mathrm{~b}-\mathrm{Cu}_{2}\left(\mathrm{SC}_{6} \mathrm{~F}_{5}\right)_{2}$} & & & $1.730(6)$ & $121.8(4)$ & [63] \\
\hline & 23.1 & $\mathrm{nr}$ & $1.717(6)$ & & \\
\hline & & & $1.710(3)$ & $123.70(17)$ & [63] \\
\hline \multirow{3}{*}{$2 \mathrm{~b}-\mathrm{Cu}_{2}(\mathrm{Carb})_{2}$} & & & $1.710(3)$ & & \\
\hline & 22.8 & $\mathrm{nr}$ & $1.726(2)$ & $120.45(15)$ & [63] \\
\hline & & & $1.728(2)$ & & \\
\hline \multicolumn{6}{|c|}{ Transition metal complex with $\mathbf{2} \mathbf{c H}$} \\
\hline \multirow{2}{*}{$2 \mathrm{cH}-\left(\mathrm{CuPPh}_{3}\right)$} & 23.6 & $2.196(3)$ & $1.761(3)$ & $124.26(17)$ & [63] \\
\hline & & & $1.777(3)$ & & \\
\hline
\end{tabular}




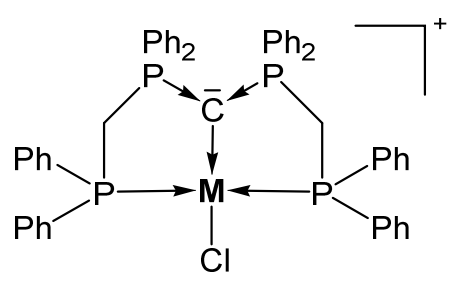

2a-NiCl; $\mathrm{M}=\mathrm{Ni}$ 2a-PdCl; $M=P d$ 2a-PtCl; $\mathrm{M}=\mathrm{Pt}$

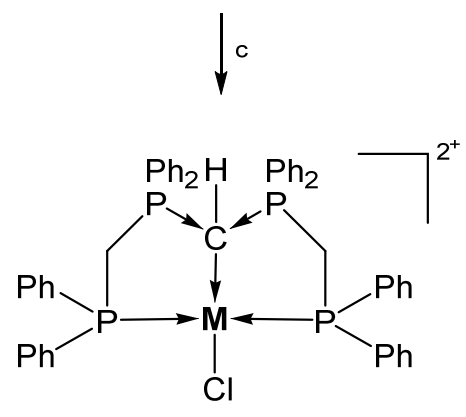

2aH-NiCl; $\mathrm{M}=\mathrm{Ni}$ 2aH-PdCl; $\mathrm{M}=\mathrm{Pd}$ 2aH-PtCl; $\mathrm{M}=\mathrm{Pt}$<smiles>C[C+](C)P(CP(c1ccccc1)c1ccccc1)[C](c1ccccc1)P(CP(c1ccccc1)c1ccccc1)c1ccccc1</smiles>

$2 \mathrm{aH}^{+}$

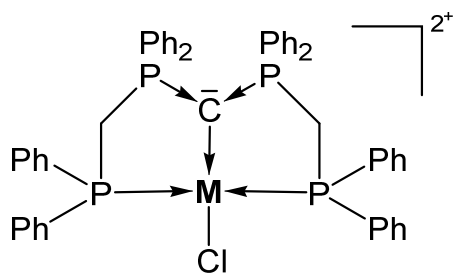

2a-AuCl; $M=A u$<smiles>C1C[Te][Te]C1</smiles>

$\left[\mathrm{CH}\left(\mathrm{PPh}_{2} \mathrm{CH}_{2} \mathrm{PPh}_{2}\right)_{2}\right]^{+}$

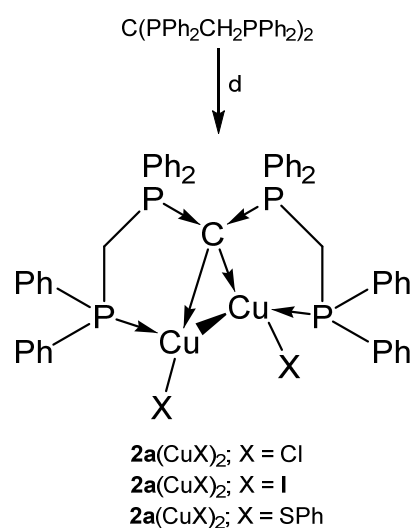<smiles></smiles>

$2 \mathrm{cH}-\mathrm{CuPPh}_{3}$

Scheme 6. Selected compounds with the pincer ligands 2a and 2aH. (a) $\mathrm{MCl}_{2}$ with a mixture of dppm and 2 eq. of $\mathrm{CS}_{2}$, (b) $\mathrm{AuCl}($ tht $) / \mathrm{HNO}_{3}$, (c) $\mathrm{HCl}$. (d) two eq. of $\mathrm{CuX}$. (e) $2{ }^{n} \mathrm{BuLi}$, [Cu(NCMe) 4 ] $\mathrm{PF}_{6} / \mathrm{PPh}_{3}$.

A series of complexes with the N,C,N pincer ligand sym-bis(2-pyridyl) tetraphenylcarbodiphosphorane $(\mathbf{2 b})$ were reported recently by the group of Sundermeyer. Remarkable is the molybdenum complex $\mathbf{2} \mathbf{b}-\left[\mathrm{Mo}_{2}(\mathrm{CO})_{7}\right]$ in which $\mathbf{2} \mathbf{b}$ provides four pairs of electrons for donation to a $\mathrm{Mo}_{2}$ unit with an Mo-Mo separation of 3.0456(5) $\AA$ [64]. This coordination mode is continued in a series of dicopper complexes presented by the same working group and prepared as depicted in Scheme 7. The addition of $[\mathrm{Cu}] \mathrm{PF}_{6}$ to $\mathbf{2 b}$ followed by treatment with two eq. of $\mathrm{PR}_{3}$ generated the cationic complexes $\left[\mathbf{2 b}-\left(\mathrm{CuPPh}_{3}\right)\right]\left(\mathrm{PF}_{6}\right)_{2}$ and $\left[\mathbf{2 b}-\left(\mathrm{CuP}\left\{\mathrm{C}_{6} \mathrm{H}_{4} \mathrm{OMe}_{3}\right]\left(\mathrm{PF}_{6}\right)_{2}\right.\right.$, respectively; $\mathbf{2 b}-(\mathrm{CuCarb})_{2}$ was obtained from $\mathbf{2 b}-(\mathrm{CuCl})_{2}$ and two eq. of $\mathrm{CarbH} / \mathrm{NaO}^{t} \mathrm{Bu}(\mathrm{CarbH}=$ carbazol) [63]. 


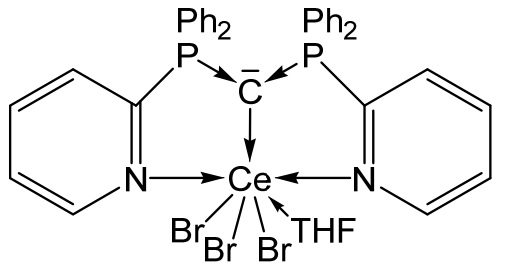

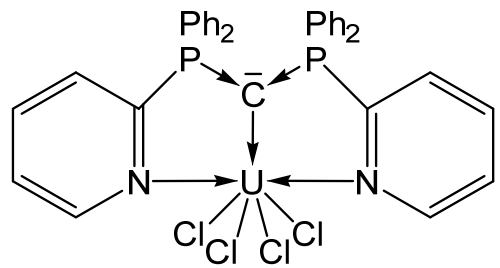

2b-CeBr${ }_{3} \mathrm{THF}$

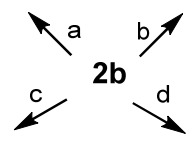

2b-UCl 4

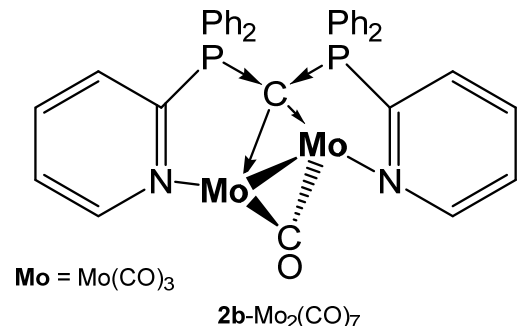

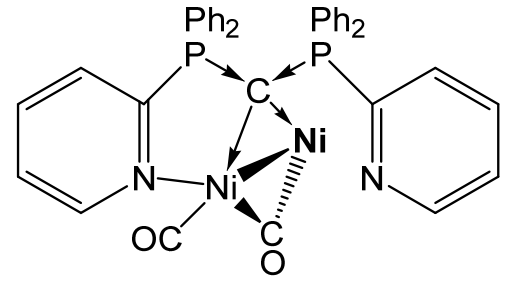

$\mathrm{Ni}=\mathrm{Ni}(\mathrm{CO})_{2} \quad \mathbf{2 b}-\mathrm{Ni}_{2}(\mathrm{CO})_{4}$

2b

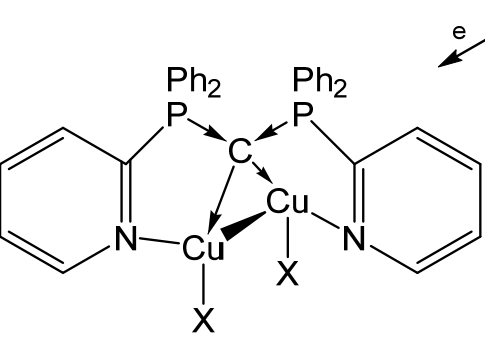

2b- $(\mathrm{CuX})_{2} ; \mathrm{X}=\mathrm{Cl}, \mathrm{I}, \mathrm{SC}_{6} \mathrm{~F}_{5}$, Carb, dications with $\mathrm{X}=\mathrm{PPh}_{3}, \mathrm{P}\left(\mathrm{C}_{6} \mathrm{H}_{4} \mathrm{OMe}\right)_{3}$

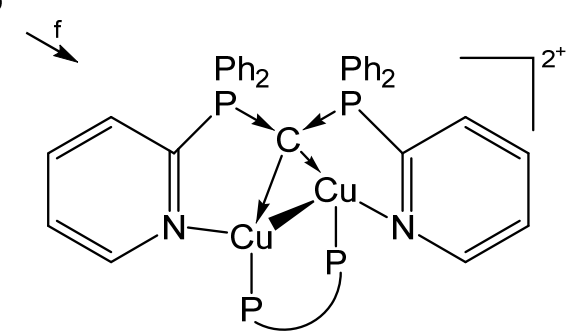

$\left[\mathbf{2 b}-\mathrm{Cu}_{2}(\mathrm{P}-\mathrm{P})\right]^{2+}:(\mathrm{P}-\mathrm{P})=$ DPEPhos, XantPhos, dppf

Scheme 7. Selected compounds with the pincer ligand $\mathbf{2 b}$ as two and four electron donor. (a) $\mathrm{CeBr}_{3}$ in $\mathrm{THF},(\mathbf{b}) \mathrm{UCl}_{4}$, (c) 2 eq. of $\mathrm{Mo}(\mathrm{CO})_{3}\left(\mathrm{NCMe}_{3}\right.$, (d) 2 eq. of $\mathrm{Ni}(\mathrm{CO})_{4}$, (e) 2 eq. of $\mathrm{CuX},(\mathbf{f}) 2$ eq. of $[\mathrm{Cu}] \mathrm{PF}_{6} / 1$ eq. of $\mathrm{P}-\mathrm{P}$.

For the cationic complexes $\left[2 \mathbf{b}-\mathrm{Cu}_{2}(\mathrm{P}-\mathrm{P})\right]^{2+}$ the chelating ligands are: $\mathrm{DPEPhos}=\mathrm{bis}[(2-$ diphenylphosphino)phenyl] ether, XantPhos $=4,5$-bis(diphenylphosphino)-9,9-dimethylxanthene, $\mathrm{dppf}=1,10$-bis(diphenyl-phosphino)ferrocene. The germinal nature of both $\mathrm{Cu}(\mathrm{I})$ centers leads to $\mathrm{Cu}-\mathrm{Cu}$ distances in the range of 2.55-2.67 $\AA$. Most of the $\mathrm{Cu}(\mathrm{I})$ complexes show photoluminescence upon irradiation with UV light at room temperature [63].

Further, $\mathbf{2} \mathbf{c H}-\mathrm{CuPPh}_{3}$ is an example of a complex with a deprotonated form of $\mathbf{2 a}$ and longer P-C distances are observed due to the protonation of the central carbon atom [63].

\subsection{Transition Metal Addition Compounds of Carbones $\mathrm{C}\left(\mathrm{PR}_{3}\right)_{2}$ with an Additional Ortho Metallated Pincer Function}

The source for the $\mathrm{Rh}$ complex $3 \mathbf{a}-\mathrm{Rh}\left(\mathrm{PMe}_{3}\right)_{2} \mathrm{H}$ was the half pincer compound $5 \mathrm{a}-\mathrm{Rh}\left(\mathrm{C}_{6} \mathrm{H}_{8}\right)$ (vide infra) upon reacting with $\mathrm{PMe}_{3}$ under loss of cod (see Scheme 8). 3a-Pt( $\left.\mathrm{SMe}_{2}\right)$ forms upon reacting 1a with $\left[\mathrm{Me}_{2} \mathrm{Pt}\left(\mathrm{SMe}_{2}\right)\right]_{2}$ and loss of 4 molecules of $\mathrm{CH}_{4}$ [69]. $\mathrm{PEt}_{3}$ replaces the labile bonded $\mathrm{SMe}_{2}$ group of $3 \mathrm{a}-\mathrm{Pt}\left(\mathrm{SMe}_{2}\right)$ to produce $3 \mathrm{a}-\mathrm{PtEt}_{3}$, which is transformed with $\mathrm{P}(\mathrm{OPh})_{3}$ into $3 \mathrm{a}-\mathrm{Pt}(\mathrm{OPh})_{3}$. The dication [3a-PtPEt $\left.3\left(\mu-\mathrm{Ag}_{2}\right) \mathrm{Et}_{3} \mathrm{PPt}-\mathbf{3 a}\right]^{2+}$ was obtained upon addition of AgOTf to $3 \mathbf{a}-\mathrm{PtPEt}_{3}$. According to the carbone $\mathrm{C}$ atom as four electron donor the $\mathrm{Pt}$ complexes with $\mu-\mathrm{Ag}$ functions show long Pt-C distances between 1.737 and $1.749 \AA$ (mean values) and the ${ }^{31}$ PNMR shifts are in the narrow range of 33 and $36 \mathrm{ppm}$ (See Table 3) [70]. More complicated is the formation of 3a-Pt(CO), which stems from the hydrolysis of the related $3 \mathrm{a}-\mathrm{Pt}\left(\mathrm{CCl}_{2}\right)$ complex (not isolated) [71]. 


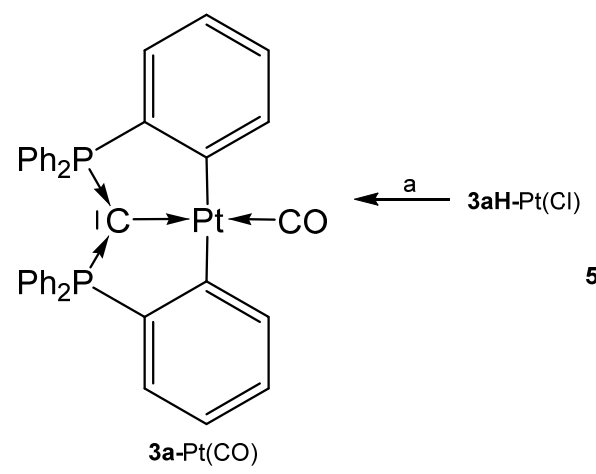

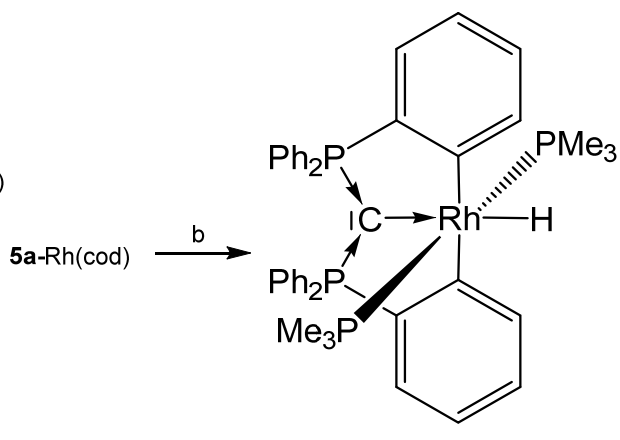

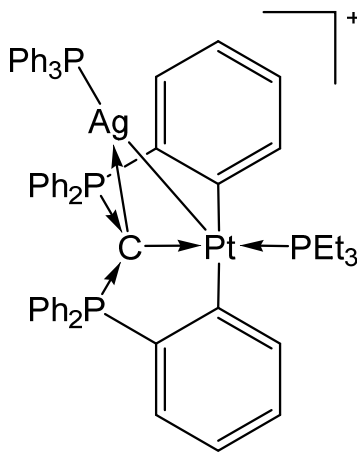

5a-Pt $\left(\mathrm{C}_{8} \mathrm{H}_{11}\right)$

3a-Rh(PMe 3$) \mathrm{H}$

$\left[3 \mathbf{a}-\mathrm{PtPEt}_{3}\left(\mu-\mathrm{AgPPh}_{3}\right)\right]^{+}$

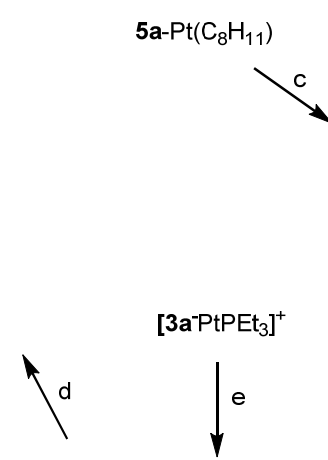<smiles>Pc1ccccc1P[C@@H](P)P(Cl)[P+](c1ccccc1)c1ccccc1</smiles>

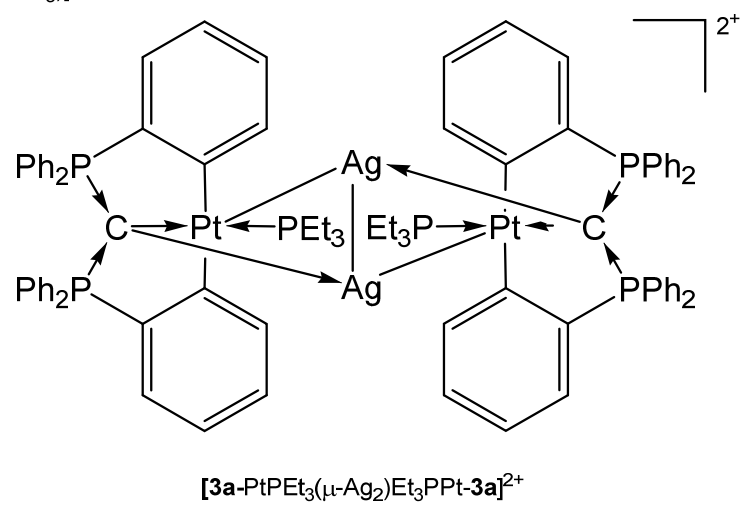

Scheme 8. Selected addition compounds with the pincer ligand $3 \mathrm{a}$ and $3 \mathrm{aH}$ and those with the Ag-bridged cations or dication, respectively. (a) from $3 \mathrm{aH}-\mathrm{PtCl}$ via $3 \mathrm{a}-\mathrm{Pt}\left(\mathrm{CCl}_{2}\right)$ and $\mathrm{H}_{2} \mathrm{O}$, (b) $\mathrm{PMe}_{3}$, (c) from 5a-Pt $\left(\mathrm{C}_{8} \mathrm{H}_{11}\right)$ (see Scheme 11) and $\mathrm{CHCl}_{3}$, (d) $\mathrm{PPh}_{3}$, (e) 2 AgOTf.

Table 3. Transition metal complexes with ortho metallated tripodal pincer ligand 3a derived from 1a and the related pincer ligand $3 \mathbf{b}$ and ${ }^{31} \mathrm{P}$ NMR shifts.

\begin{tabular}{|c|c|c|c|c|c|}
\hline 3-M & ${ }^{31}$ P NMR & C-M & P-C & P-C-P & Ref \\
\hline \multicolumn{6}{|c|}{ Transition metal complexes with the tripodal ligand $\mathbf{3 a}$} \\
\hline $3 a-R h\left(\mathrm{PMe}_{3}\right)_{2} \mathrm{H}$ & 8.56 & $2.203(3)$ & $1.674(3)$ & 138.32(18) & [69] \\
\hline 3a-PtSMe 2 & 30.42 & $\mathrm{nr}$ & $\mathrm{nr}$ & $\mathrm{nr}$ & [69] \\
\hline $3 a-P t C O$ & 41.5 & $2.037(5)$ & $1.706(3)$ & $128.4(3)$ & [71] \\
\hline 3a-PtPEt 3 & 28.5 & $2.067(2)$ & $1.697(2)$ & $124.88(14)$ & [70] \\
\hline 3a-PtP $(\mathrm{OPh})_{3}$ & $\mathrm{nr}$ & $\mathrm{nr}$ & $\mathrm{nr}$ & $\mathrm{nr}$ & [70] \\
\hline$\left[3 a-\mathrm{PtPEt}_{3}\left(\mu-\mathrm{AgPPh}_{3}\right)_{3}\right](\mathrm{OTf})$ & 32.5 & $2.130(4)$ & 1.737 & $126.0(2)$ & [70] \\
\hline$\left[3 \mathbf{a}-\mathrm{PtP}(\mathrm{OPh})_{3}\left(\mu-\mathrm{AgPEt}_{3}\right](\mathrm{OTf})\right.$ & 36.0 & $2.105(3)$ & 1.743 & $122.9(2)$ & [70] \\
\hline$\left[3 \mathbf{a}-\mathrm{PtPEt}_{3}\left(\mu-\mathrm{Ag}_{2}\right) \mathrm{Et}_{3} \mathrm{PPt}-3 \mathrm{a}\right](\mathrm{OTf})_{2}$ & 33.4 & $2.128(3)$ & 1.749 & $125.29(18)$ & [70] \\
\hline 3aH-PtCl & 27.9 & $2.077(6)$ & $1.796(6)$ & $123.4(4)$ & [71] \\
\hline \multicolumn{6}{|c|}{ Transition metal complexes with the tripodal ligand $\mathbf{3 b}$} \\
\hline $3 b-P t(C O)$ & 46.9 & $2.002(5)$ & $\mathrm{nr}$ & $133.3(3)$ & [72] \\
\hline
\end{tabular}


The carbone complex $3 \mathbf{b}-\mathrm{Pt}(\mathrm{CO})$ was obtained from reacting the yldiide platinum complex (see Scheme 9) with $1 \mathrm{~atm} \mathrm{CO}$ that inserts into the N-Si bond of the yldiide.

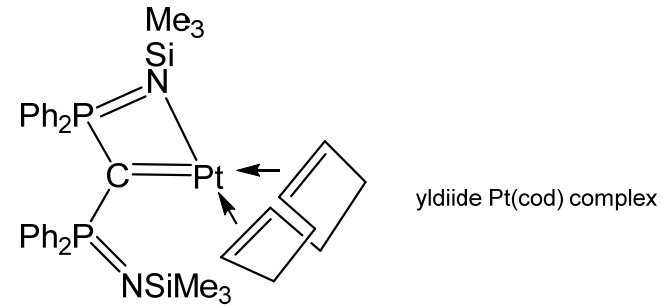<smiles></smiles><smiles>COC1=NP(c2ccccc2)[C@@H]2[PH](c3ccccc3)=NC(OC)[P@]12Cl</smiles>

3ba<smiles>COC1=NP(c2ccccc2)[C@@H]2[PH](c3ccccc3)N=C(OC)[P@]12Cl</smiles>

$3 b b$

Scheme 9. Two mesomeric forms of $3 b-\mathrm{Pt}(\mathrm{CO})$; $3 \mathbf{b a}$ favors a tricarbene coordination at $\mathrm{Pt}(0)$ whereas $3 \mathbf{b b}$ is consistent $\mathrm{Pt}(\mathrm{II})$ forming two C-Pt s-bonds similar to 3a-Pt(CO). The short central C-Pt bond length of $2.002 \AA$ indicates a partial doubly donation of the carbone $\mathrm{C}$ atom as shown in Figure 5 . The planar environment at $\mathrm{Pt}$ is typical for $\mathrm{Pt}(\mathrm{II})$ and supports this view [72].<smiles>c1ccc(P2[Y14]3Cc4ccccc4C3Pc3ccccc32)cc1</smiles>

$3 a$<smiles></smiles>

$3 \mathbf{b}$

Figure 5. Bis-ortho metallated pincer complexes $\mathbf{3 a}$ and $\mathbf{3 b}$.

\subsection{Transition Metal Complexes with P-C-P Five Membered Ring}

The carbone 4 (see Figure 6) was obtained by deprotonation of the cation $[4 \mathbf{H}]^{+}$. According to two $\mathrm{P}$ atoms in different chemical environments two doublets in the ${ }^{31} \mathrm{P}$ NMR spectrum were recorded at $\delta=60.0$ and $71.5 \mathrm{ppm} ;{ }^{2} \mathrm{JP}_{\mathrm{PP}}=153 \mathrm{~Hz}$. From X-ray determination stem the P-C(1) and P-C(2) distances of 1.644(19) and 1.657(17) $\AA$, respectively, and the P-C-P angle amounts to 104.82(10) ${ }^{\circ}$ [73]. The bond lengths (see Table 4) are close to that reported for the carbone $\mathbf{1 a}$. 


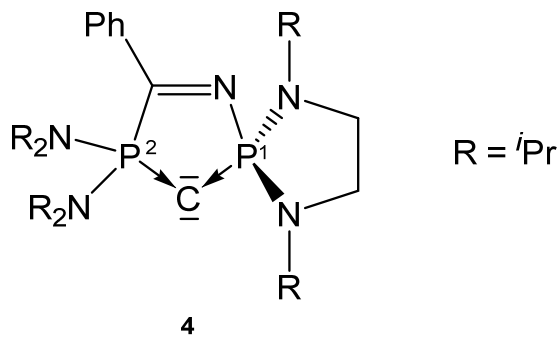

Figure 6. Structure of compound 4 .

Table 4. Transition metal complexes with the cyclic carbone 4, containing ${ }^{31} \mathrm{P}$ NMR shifts and relevant structural parameters.

\begin{tabular}{cccccc}
\hline 4-M & 31P NMR & M-C & $\mathbf{P}^{1}-\mathbf{C} \mathbf{P}^{\mathbf{2}}-\mathbf{C}$ & P-C-P & Ref \\
\hline 4-PdCl( $\pi$-C3H5) & $61.271 .9(225)$ & $2.120(2)$ & $1.673(2) 1.694(2)$ & $106.66(13)$ & {$[73]$} \\
4-RhCl(nbd) & $64.675 .7(230)$ & $2.115(18)$ & $1.676(18) 1.702(18)$ & $106.86(10)$ & {$[73]$} \\
4-Rh(CO)2Cl & $68.275 .6(224)$ & $\mathrm{nr}$ & $\mathrm{nr}$ & $\mathrm{nr}$ & {$[73]$} \\
4-AuOBut & $64.160 .4(225)$ & $2.018(6)$ & $1.674(7) 1.687(7)$ & $108.5(4)$ & {$[74]$} \\
4-CuOBut & $69.862 .6(195)$ & $1.8923(15)$ & $1.6763(15) 1.6887(15)$ & $106.90(8)$ & {$[74]$} \\
4-CuCl & $63.270 .6(186)$ & $1.8914(19)$ & $1.6700(19) 1.6869(19)$ & $107.20(11)$ & {$[74]$} \\
\hline
\end{tabular}

From the cyclic and asymmetric carbone 4 six transition metal complexes (see Scheme 10) are known in which the ligand acts as two electron donor via the $\mathrm{C}$ atom. As in the starting compound 4 the $\mathrm{P}^{2}-\mathrm{C}$ bond distances are slightly longer than $\mathrm{P}^{1}-\mathrm{C}$ bond. Addition of $\mathrm{CuCl}$ and $\mathrm{AuCl}\left(\mathrm{SMe}_{2}\right)$ to $4 \mathrm{H}^{+} / \mathrm{tBuOK}$ generates the compounds $4-\mathrm{CuO} t \mathrm{Bu}$ and $4-\mathrm{AuO} t \mathrm{Bu}$, respectively. In $\mathrm{CH}_{3} \mathrm{Cl}_{2}$ or $\mathrm{CHCl}_{3} 4-\mathrm{CuO} t \mathrm{Bu}$ is converted into 4-CuCl [74]. 4- $\mathrm{Rh}(\mathrm{CO})_{2} \mathrm{Cl}$ stems from the reaction of 4 with $\left[\left\{\mathrm{RhCl}(\mathrm{CO})_{2}\right\}_{2}\right][73] .4-\mathrm{CuOtBu}$ and $4-\mathrm{AuOt} \mathrm{Bu}$ catalyze the hydroamination or hydroalkoxylation of acrylonitrile [74].

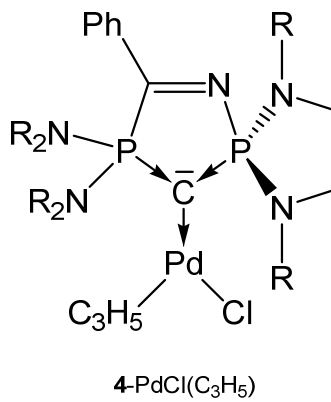

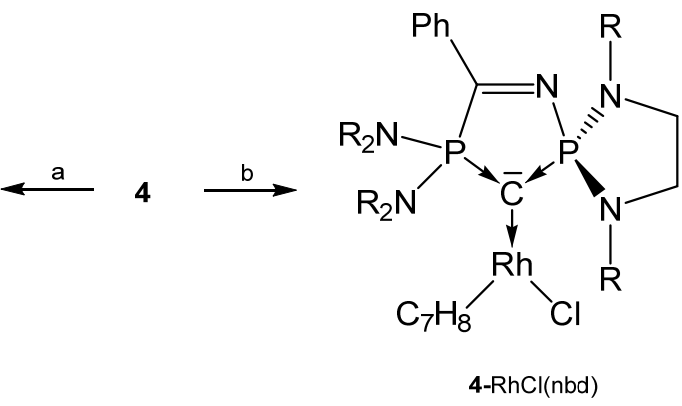

Scheme 10. Selected complexes with the cyclic carbone $4 . \mathrm{R}={ }^{i} \mathrm{Pr}$. a) $\left.\left[\{\mathrm{PdCl}(\text { allyl })\}_{2}\right], \mathrm{b}\right)\left[\{\mathrm{RhCl}(\mathrm{nbd})\}_{2}\right]$.

\subsection{Transition Metal Complexes with Asymmetric P-C-P Ligands}

Several asymmetric carbones with orthometallation (5a-M, $5 \mathbf{d}-\mathbf{M})$, with an additional donor function $(\mathbf{5 c})$, or with a functionalized phenyl ring $(\mathbf{5 b})$ were reported that form TM complexes (see Figure 7). 
<smiles>[X]c1ccccc1P([P+]#P)c1ccccc1</smiles>

5a-M<smiles>P#CP(c1ccccc1)c1ccccn1</smiles>



5b<smiles>[Y4]C([P+]([PH2+])c1ccccc1C)[PbH](c1ccccc1)c1ccccc1C</smiles>

$5 d-M$

Figure 7. Structures of compounds $5 \mathbf{a}-\mathbf{M}, 5 \mathbf{b}, \mathbf{5 c}$ and $5 \mathrm{~d}-\mathbf{M}$.

The neutral asymmetric carbone $5 \mathbf{b}\left(\mathrm{X}=\mathrm{PPh}_{2}\right)$ has the structural parameters $\mathrm{P}^{1}-\mathrm{C}=1.642(2)$, $\mathrm{P}^{2}-\mathrm{C}=1.636(1) \AA$, and a P-C-P angle of $140.74(8)^{\circ}$ (see Table 5); the P atoms resonate at $\delta=-6.9$ and $-3.4 \mathrm{ppm}\left({ }^{2} \mathrm{~J}_{\mathrm{PP}}=93 \mathrm{~Hz}\right)[75]$. Those of $5 \mathrm{c}$ are $\mathrm{P}^{1}-\mathrm{C}=1.6416(16) \AA, \mathrm{P}^{2}-\mathrm{C}=1.6398(17) \AA$, and P-C-P $=133.25(10)^{\circ}[76]$. Three complexes in which the carbone $\mathbf{1 a}$ is half-side orthometallated forming 5a-M complexes are described [69,73,77].

Table 5. Transition metal complexes with the unsymmetrical carbones $\mathbf{5 a - 5 d} ;{ }^{31} \mathrm{P}$ NMR shifts in ppm.

\begin{tabular}{|c|c|c|c|c|c|}
\hline 5-M & ${ }^{31} \mathrm{P}$ NMR $\left({ }^{2} \mathrm{JPP}_{\mathrm{PP}}\right)$ & M-C & $\mathrm{P}^{1}-\mathrm{C} \mathrm{P}^{2}-\mathrm{C}$ & P-C-P & Ref. \\
\hline \multicolumn{6}{|c|}{ Transition metal complexes of $\mathbf{5 a}-\mathbf{M}$} \\
\hline 5a-Ptcod $\left(\mathrm{C}_{8} \mathrm{H}_{11}\right)$ & $14.95 .7(59.8)$ & $2.072(3)$ & $1.694(4) 1.716(4)$ & $114.8(2)$ & [77] \\
\hline $5 a-R h \operatorname{cod}(p)$ & $10.1512 .40(50.9)$ & $2.165(2)$ & $1.693(2) 1.692(2)$ & $124.50(13)$ & [69] \\
\hline $5 a-P d C_{3} \mathrm{H}_{5}$ & $39.89 .9(54)$ & $\mathrm{nr}$ & $\mathrm{nr}$ & $\mathrm{nr}$ & [73] \\
\hline \multicolumn{6}{|c|}{ Transition metal complexes with the carbone $\mathbf{5 b}$} \\
\hline $5 \mathbf{b}-\mathrm{AuCl}\left(\mathrm{X}=\mathrm{PPh}_{2}\right)$ & $8.618 .7(52)$ & 2.043 & $1.701(4) 1.696(2)$ & $126.0(2)$ & [75] \\
\hline $5 \mathbf{b}-\mathrm{AuCl}\left(\mathrm{X}=\mathrm{PPh}_{2}-\mathrm{AuCl}\right)$ & $25.620 .2(47)$ & 2.037(3) & $1.690(3) 1.689(3)$ & $131.4(2)$ & [75] \\
\hline $\begin{array}{c}5 \mathbf{b}-(\mathrm{AuCl})_{2} \\
\left(\mathrm{X}=\mathrm{PPh}_{2}-\mathrm{AuCl}\right)\end{array}$ & 25.426 .9 & 2.0892 .064 & $1.774(5) 1.763(5)$ & $123.6(3)$ & [75] \\
\hline 5b-PtMe $2(X=\mathrm{Me})$ & 19.3 & $\mathrm{nr}$ & $\mathrm{nr}$ & $\mathrm{nr}$ & [78] \\
\hline \multicolumn{6}{|c|}{ Transition metal complexes with the carbone $5 \mathrm{c}$} \\
\hline $5 c-U_{4}$ & par & 2.461(5) & $1.699(5) 1.711(5)$ & $120.6(3)$ & [41] \\
\hline$[5 \mathrm{cAuPPh}]^{+}$ & $19.7015 .03(30.7)$ & 2.067(9) & $1.688(9) 1.707(9)$ & $124.3(5)$ & [76] \\
\hline$\left[5 \mathrm{c}(\mathrm{CuCl})\left(\mathrm{AuPPh}_{3}\right)\right]^{+}$ & $39.726 .2(\mathrm{~m})$ & 2.111(4) Au 1.981(5) Cu & $1.732(5) 1.750(5)$ & $120.2(3)$ & [76] \\
\hline$\left[5 \mathrm{c}(\mathrm{AuCl})\left(\mathrm{AuPPh}_{3}\right)\right]^{+}$ & $35.427 .5(\mathrm{~m})$ & 2.080(9) $\mathrm{Au}^{2} 2.127(8) \mathrm{Au}^{1}$ & $1.756(9)$ & $119.3(5)$ & [76] \\
\hline \multicolumn{6}{|c|}{ Transition metal complexes with the carbone $5 \mathbf{d}-\mathbf{M}$} \\
\hline $5 d-P t-5 d$ & 19.3 & $\mathrm{nr}$ & $\mathrm{nr}$ & $\mathrm{nr}$ & [78] \\
\hline
\end{tabular}

As depicted in Scheme 11, three neutral complexes of 1a are known in which one of its phenyl group is orthometallated to produce the 5a-M core. The ${ }^{31} \mathrm{P}$ NMR shift of the unchanged $\mathrm{PPh}_{3}$ group range between about 6 and 13 ppm whereas for the orthometallated side shifts between 15 and 40 ppm where recorded. Both P-C distances do not differ markedly and amount to about $1.700 \AA$. 


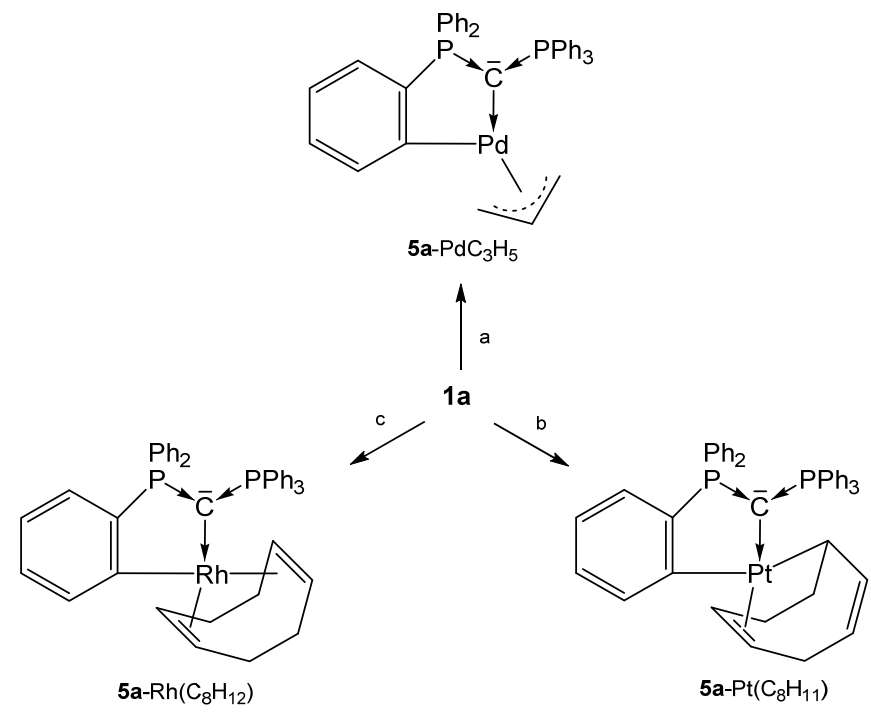

Scheme 11. Selected structures of transition metal complexes with the carbone $5 \mathbf{a}$; (a) $\frac{1}{2}[\mathrm{PdCl}($ allyl); (b) $1 / 3\left[\mathrm{PtI}_{2}(\mathrm{cod})\right] ;$ (c) $\frac{1}{4}[\mathrm{RhCl}(\mathrm{cod})]$. All complexes are formed upon release of the cation $[\mathbf{1 a H}]^{+}$.

All complexes shown in Scheme 12 have a further $\mathrm{PPh}_{2}$ function at the ortho position of one phenyl group of $\mathbf{1 a}$. In the complex $5 \mathbf{b}-(\mathrm{AuCl})_{2}$ the carbone provides four electrons for donation with typical long P-C distances of about $1.770 \AA$ [75].

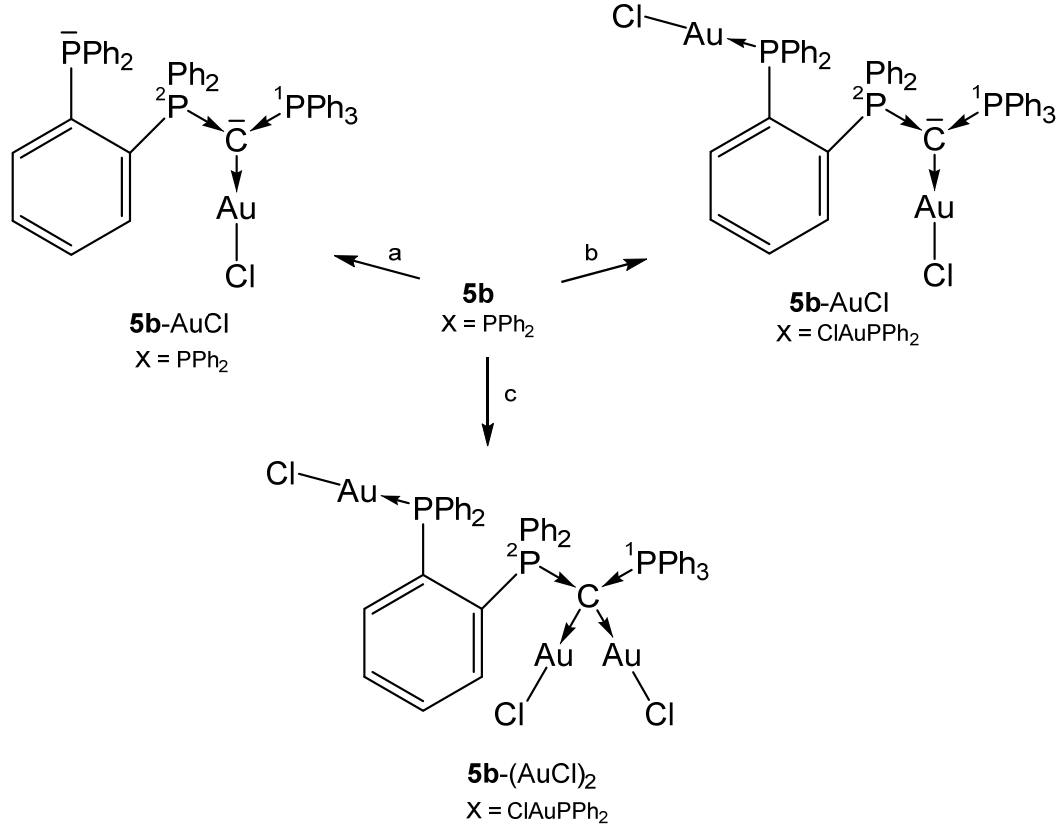

Scheme 12. Selected structures of transition metal complexes with the carbone $5 b$. (a) [AuCl(tht)], (b) 2 [AuCl(tht), 3 [AuCl(tht)].

The paramagnetic $5 \mathrm{c}-\mathrm{UCl}_{4}$ exhibits a short $\mathrm{C}$ - $\mathrm{U}$ distance indicative for a double dative bond of the carbone $\mathrm{C}$ atom as in $\mathbf{2} \mathbf{b}-\mathrm{UCl}_{4}$ and was obtained by reacting $\mathrm{UCl}_{4}$ with the dication $\mathbf{5 c}-\mathrm{H}_{2} / \mathrm{NaHMDS}$. Upon further coordination of the pyridyl group (U-N $=2.537(4) \AA$ ) the $U$ atom attains the coordination number 6 [41].

$\left[5 \mathrm{c}-\mathrm{AuPPh}_{3}\right]^{+}$was obtained from reacting the carbone $5 \mathrm{c}$ with $\left[\mathrm{PPh}_{3} \mathrm{AuCl}\right] / \mathrm{Na}\left[\mathrm{SbCl}_{6}\right]$ (see Scheme 13). In the cationic complex $\left[5 c-(\mathrm{CuCl})\left(\left(\mathrm{AuPPh}_{3}\right)\right] \mathrm{SbF}_{6}\right.$, the carbone $\mathbf{5 c}$ acts as a six-electron donor with a Cu-N distance of 2.267(6) $\AA$ and $\mathrm{Cu}-\mathrm{Au}$ separation of 2.8483(10) $\AA$. The $\mathrm{Cu}$ and $\mathrm{Cl}$ atoms 
are each disordered over two positions with occupancy of about 0.8 to 0.2 . If $\mathrm{CuCl}$ is replaced by $\mathrm{AuCl}$ as in $\left[5 \mathrm{c}-(\mathrm{AuCl})\left(\mathrm{AuPPh}_{3}\right)\right] \mathrm{SbF}_{6}$ the $\mathrm{C}-\mathrm{AuPPh}_{3}$ distance is slightly elongated and no coordination of the pyridyl N atom is observed. The Au-Au separation is with 3.1274(6) $\AA$ too long for a metallophilic interaction. In both compounds, the carbone $\mathrm{C}$ atom constitutes a chiral center according to four chemical different substituents and acts as a four-electron donor. The $\mathrm{PPh}_{3}$ group resonates between 15 and $27 \mathrm{ppm}$ [76]. In the related symmetric pyridyl-free complex 1a-( $\mathrm{AuCl})_{2}$, slightly shorter $\mathrm{C}-\mathrm{Au}$ (2.076(3) $\AA$ ) were recorded accompanied by longer P-C (1.776(3) $\AA$ ) bond lengths [51].

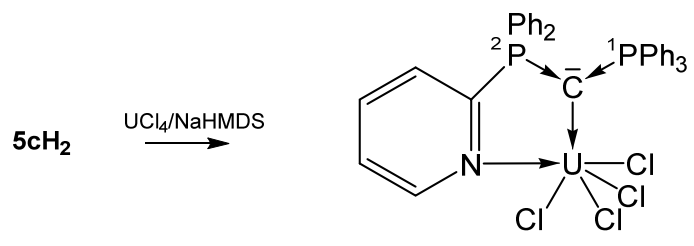

$5 \mathrm{c}-\mathrm{UCl}_{4}$

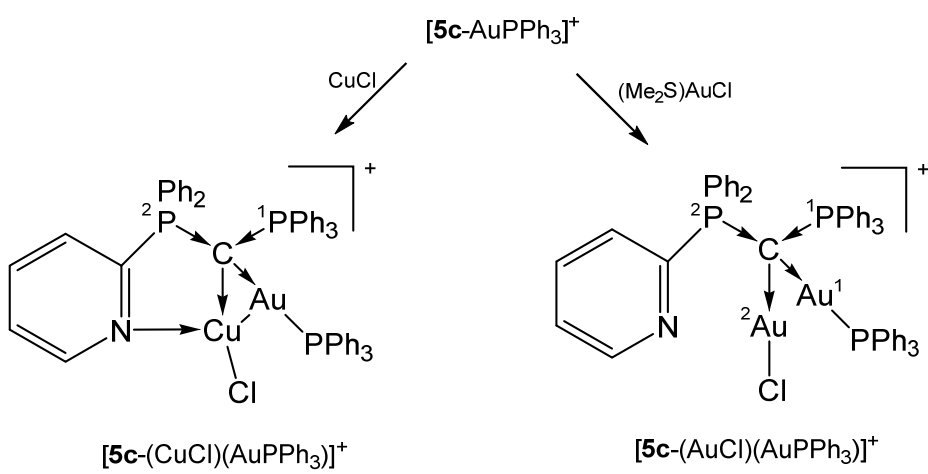

Scheme 13. Selected structures of transition metal complexes with the mono pyridyl substituted carbone $5 c$.

\subsection{Transition Metal Complexes of Carbones with Cyclobutadiene}

The carbones $\mathbf{6 a}$ and $\mathbf{6 b}$ (see Figure 8) can also be seen as an all-carbon four-membered ring bent allene (CBA); $6 \mathrm{a}$ is stable for several hours at $-20^{\circ}$ but decomposes when warmed up to $-5^{\circ}$. The optimized geometry reveals a very acute allene bond angle of $85.0^{\circ}$ and coplanarity of the ring carbon atoms including the two nitrogen atoms. The $\mathrm{C}=\mathrm{C}$ bonds of the allene fragment amount to $1.423 \AA$ and are significantly longer than in typical linear allenes (1.31 $\AA$ ). Short CN bonds of $1.36 \AA$ indicate some double bond character. The CCC carbon atom resonates in the ${ }^{13} \mathrm{C}$ NMR spectrum at 151 ppm. The first and second proton affinities (PAs) are very high amounting to 307 and $152 \mathrm{kcal} / \mathrm{mol}$ [79].

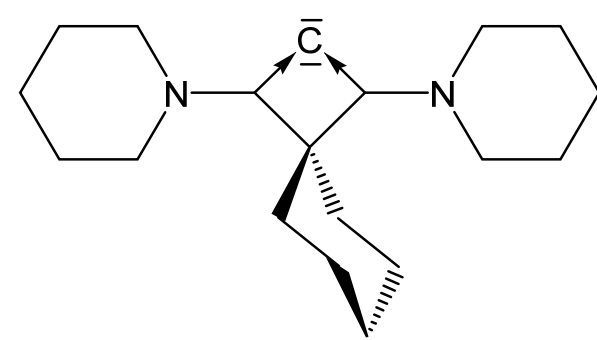

$6 a$

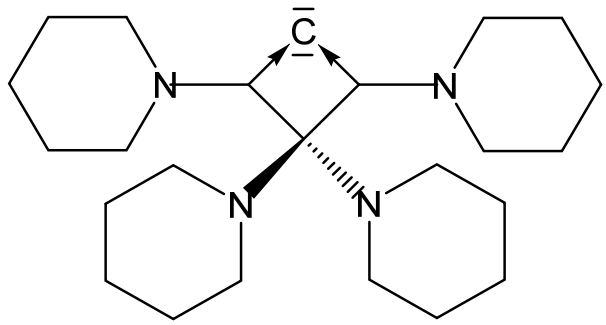

6b

Figure 8. Structures of compounds $6 \mathbf{a}$ and $\mathbf{6 b}$.

The molecular orbitals show that the HOMO and HOMO-1 have clearly the largest coefficients at the central carbon atom and exhibit the typical shape of lone-pair molecular orbitals with $\sigma(\mathrm{HOMO})$ and 
$\pi$ (HOMO-1) symmetry; however, with reversed order with respect to CDPs and CDCs. To emphasize the proximity of 6 to CDP carbones, we use the same symbolism mimicking a metal.

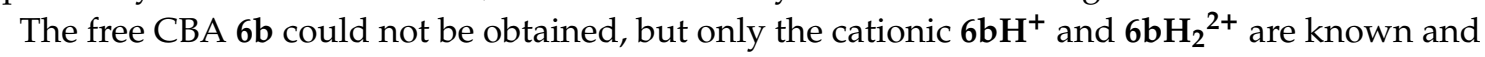
used as starting compounds for the syntheses of the related transition metal complexes [80].

The ${ }^{13} \mathrm{C}$ NMR shifts of the central carbon atom are shifted to higher fields relative to the starting free carbone ranging between 124 and 139 ppm (see Table 6).

Table 6. Transition metal complexes with the all carbon ligand $6 ;{ }^{13} \mathrm{C}$ NMR shifts (in ppm) of the donating carbon atom. Distances in $\AA$, angles in deg.

\begin{tabular}{|c|c|c|c|c|c|}
\hline & ${ }^{13} \mathrm{C}$ NMR & C-M & $\mathrm{C}-\mathrm{C}$ & C-C-C & Ref. \\
\hline \multicolumn{6}{|c|}{ Transition metal complexes with the carbone $\mathbf{6 a}$} \\
\hline 6a- $\mathrm{RhCl}(\mathrm{cod})$ & 136.6 & $2.038(5)$ & $1.405(6)$ & $88.4(3)$ & [79] \\
\hline 6a- $\operatorname{IrCl}(\operatorname{cod})$ & 138.6 & $\mathrm{nr}$ & $\mathrm{nr}$ & $\mathrm{nr}$ & [79] \\
\hline 6a- $\mathrm{RhCl}(\mathrm{CO})_{2}$ & 124.7 & $\mathrm{nr}$ & $\mathrm{nr}$ & $\mathrm{nr}$ & [79] \\
\hline 6a-IrCl(CO) $)_{2}$ & 129.2 & $\mathrm{nr}$ & $\mathrm{nr}$ & $\mathrm{nr}$ & [79] \\
\hline \multicolumn{6}{|c|}{ Transition metal complexes with the carbone $\mathbf{6 b}$} \\
\hline $\mathbf{6 b}-\mathrm{W}(\mathrm{CO})_{5}$ & 130.1 & $2.319(3)$ & $1.419(4)$ & $88.0(2)$ & [80] \\
\hline 6b-AuCl & 123.6 & $2.001(4)$ & $1.409(5)$ & $90.5(3)$ & [80] \\
\hline $\mathbf{6 b}-\mathrm{RhCl}(\mathrm{CO})_{2}$ & 131.2 & $2.0602(14)$ & $1.4102(19)$ & $89.73(11)$ & [80] \\
\hline
\end{tabular}

All complexes of the CBA $\mathbf{6 a}$ where obtained by reacting the freshly prepared free carbone $\mathbf{6 a}$ at $-20^{\circ}$ with $\left[\{\mathrm{MCl}(\mathrm{cod})\}_{2}\right]$ complexes $(\mathrm{M}=\mathrm{Rh}, \mathrm{Ir})$. The cod ligand can be replaced by bubbling CO through solutions of $\mathbf{6 a}-\mathrm{MCl}(\mathrm{cod})$ to produce the related $\mathbf{6 a}-\mathrm{MCl}(\mathrm{CO})_{2}$ compounds (see Scheme 14) [79].

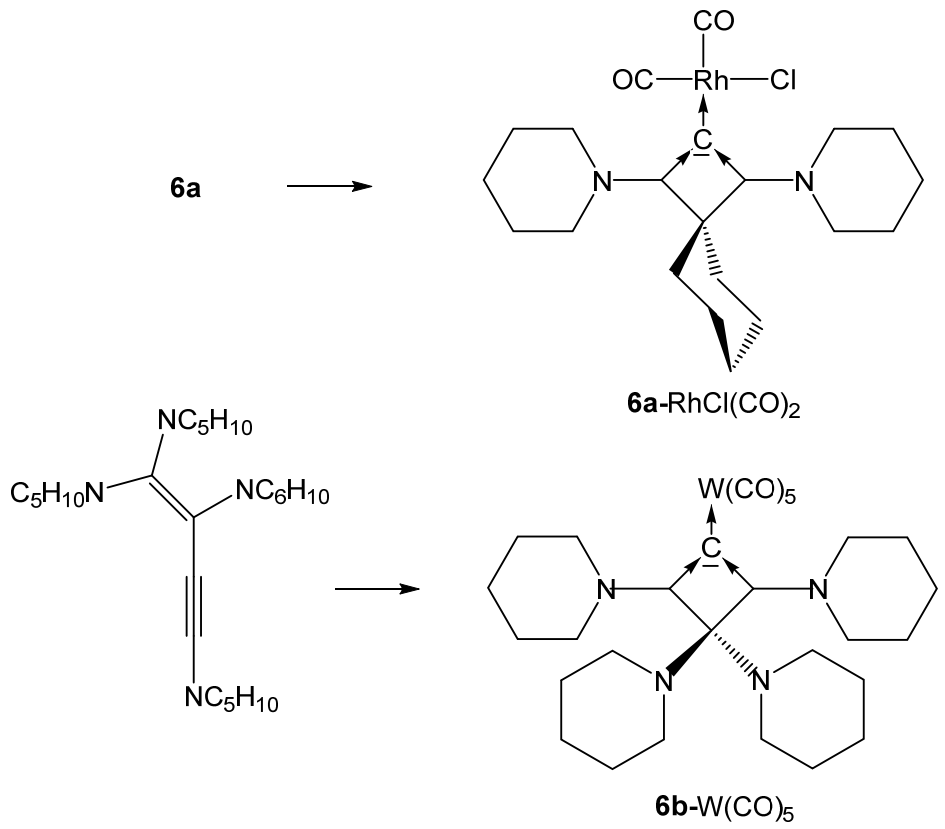

Scheme 14. Selected structures of complexes with the cyclic carbones $\mathbf{6 a}$ and $\mathbf{6} \mathbf{b}$. Preparation see text.

Transition metal complexes with $\mathbf{6 b}$ as ligand were obtained by reacting 1,1,2,4-tetrapiperidino-1 -buten-3-yne with (a) $[($ tht $) \mathrm{AuCl}],(\mathrm{b})\left[\mathrm{RhCl}(\mathrm{CO})_{2}\right]_{2}$, and (c) $\left[\left(\mathrm{NMe}_{3}\right) \mathrm{W}(\mathrm{CO})_{5}\right]$ during the reaction rearrangement of the starting buten-3-yne to $6 \mathbf{b}$ has occurred [80].

\subsection{Carbodicyclopropenylidene}

Stephan described the first carbodicarbene stabilized by flanking cyclopropylidenes, named carbodicyclopropylidene 7 (see Figure 9) [81]. 

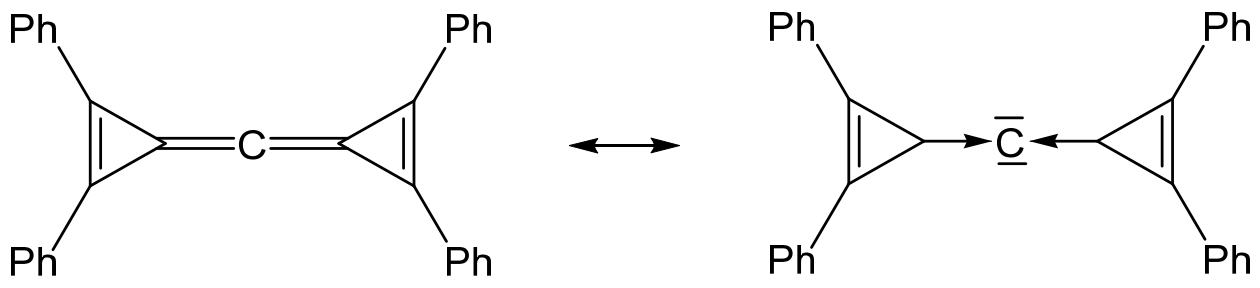

7

Figure 9. Possible description of the bonding in the carbone 7.

Neither the neutral singlet 1,2-diphenylcyclopropenylidene as carbene ligand L in 7 nor the carbone tetraphenylcarbodicyclopropenyliden (CDC) 7 itself are stable compounds at room temperature. The free carbene $\mathrm{L}$ has only been observed in an argon matrix isolated at $10 \mathrm{~K}$ and 7 could be characterized in solution by low temperature NMR spectroscopy; for the central carbon atom a ${ }^{13} \mathrm{C}$ NMR shift at $\delta=133 \mathrm{ppm}$ was recorded at $-60^{\circ} \mathrm{C}$.

The first and second proton affinities of 7 were determined to be 283 and $153 \mathrm{kcal} / \mathrm{mol}$, respectively. The molecular structure of 7 was determined by computational methods. Calculations reveal that the central carbon atom is in a linear environment the C-C distances were calculated at $1.308 \AA$ and the C-C-C angle to $180^{\circ}$. The energy difference between the linear allenic structure and the bent arrangement is shallow amounting to $6.6 \mathrm{kcal} / \mathrm{mol}$ for a bending angle of $140^{\circ}$ and $10 \mathrm{kcal} / \mathrm{mol}$ for $130^{\circ}$. The highest occupied molecular orbital (HOMO) and HOMO- 1 of 7 are degenerate and incorporate the $\mathrm{p}(\pi)$ orbitals of the C2-C1-C2a fragment.

The central $C$ atom is more negatively charged ( -0.19 a.u.) than the adjacent $C$ atoms, suggesting nucleophilic character [81].

The addition compounds [7-AuNHC-Ad](OTf) and [7-AuNHC-Dipp](OTf) (see Table 7) were prepared from reacting $[7 \mathrm{H}]^{+}$with $\mathrm{KHMDS}$ and the related (NHC)AuOTf at $-45^{\circ}$ (see Scheme 15) [81].

Table 7. Complexes with the carbone $7 .{ }^{13} \mathrm{C}$ NMR shifts (in ppm) of the donating carbon atom.

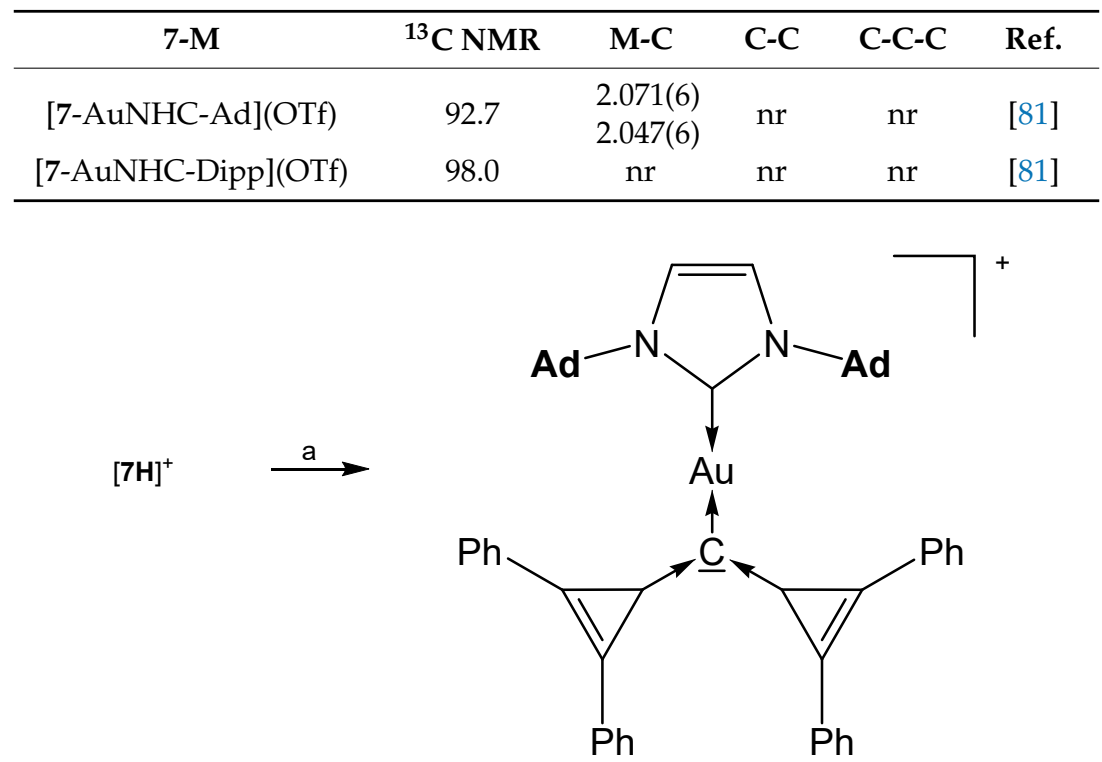

7-AuNHC-Ad

Scheme 15. Selected structures of complexes with the cyclo propylidene stabilized carbone 7 . (a) KHMDS/(NHC)AuOTf. 


\subsection{Carbodicarbenes}

Carbodicarbenes, CDCs, are neutral compounds where a bare carbon atom with its four electrons is stabilized by two NHC ligands which plays the role of a phosphine group as in carbodiphosphoranes, CDPs. Theoretical studies have demonstrated that this class of compounds could be stable and their existence was predicted by Frenking [82] and short times later realized by the group of Bertrand [83].

Structural and spectroscopic parameters of the following symmetric CDCs (see Figure 10) are available: 8a, C-C = 1.343(2) $\AA, C-C-C=134.8(2)^{\circ},{ }^{13} \mathrm{C}$ NMR 110.2 ppm [83]; 8b, C-C = 1.333(2) $\AA$ and

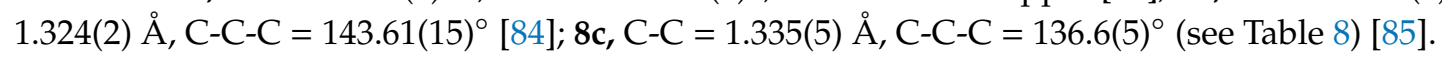<smiles>CN1c2ccccc2N(C)C1CC1N(C)c2ccccc2N1C</smiles>

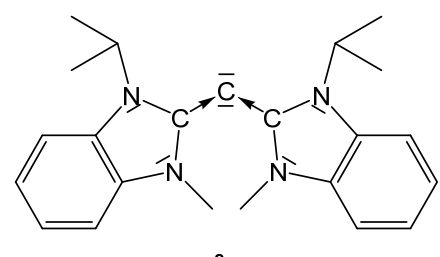<smiles>CN1c2ccccc2N(C)C1CC1N(C)c2ccccc2N1Cc1ccccc1</smiles>

8b<smiles>CCCCCCCCN1c2ccccc2N(CCCCC)[C@@H]1CC1N(C)c2ccccc2N1C</smiles>

$8 d$

Figure 10. Symmetrical CDCs from which transition metal complexes are known.

Table 8. Collection of transition metal complexes with the CDCs $\mathbf{8 a}-\mathbf{8 h} .{ }^{13} \mathrm{C}$ NMR shifts of the central carbon atom (in ppm).

\begin{tabular}{|c|c|c|c|c|c|}
\hline & ${ }^{13} \mathrm{C}$ NMR & M-C & C-C & C-C-C & Ref. \\
\hline \multicolumn{6}{|c|}{ Transition metal complexes with the CDC 8a } \\
\hline $8 a-\operatorname{RhCl}(\mathrm{CO})_{2}$ & 64.1 & $2.089(7)$ & $1.398(10)$ & $121.2(7)$ & [83] \\
\hline $8 \mathbf{a}-\mathrm{RuCl}_{2}(=\mathrm{CHPh}) \mathrm{NHC}$ & 73.01 mes & $2.2069(18)$ & $1.352(3) 1.429(3)$ & $119.84(17)$ & [86] \\
\hline $8 \mathrm{a}-\mathrm{RuCl}_{2}(=\mathrm{CHPh}) \mathrm{NHC}$ & $73.4^{\mathrm{i}} \operatorname{Pr}$ & $2.210(7)$ & $1.345(11) 1.439(9)$ & $116.9(6)$ & [86] \\
\hline \multicolumn{6}{|c|}{ Transition metal complexes with the CDC $\mathbf{8 b}$} \\
\hline$[8 \mathrm{~b}-\mathrm{PdCl}]^{+}$ & $\mathrm{nr}$ & $1.973(3)$ & $1.369(5) 1.398(5)$ & $126.5(3)$ & [84] \\
\hline$\left[8 \mathbf{b}-\mathrm{Fe}_{0.5}\right]^{2+}$ & & $2.018(3)$ & $1.374(3)$ & 128.4(3) & [87] \\
\hline$\left[8 \mathbf{b}-\mathrm{Fe}_{0.5}\right]^{3+}$ & & $1.968(4)$ & $1.387(6)$ & $125.2(4)$ & [87] \\
\hline$\left[8 b-F_{0.5}\right]^{4+}$ & & $1.928(3)$ & $1.407(4)$ & $125.4(2)$ & [87] \\
\hline \multicolumn{6}{|c|}{ Transition metal complexes with the CDC 8c } \\
\hline $8 \mathrm{c}-\mathrm{PdClC}_{3} \mathrm{H}_{5}$ & $\mathrm{nr}$ & $2.207(4)$ & $1.404(5) 1.377(5)$ & $119.7(4)$ & [85] \\
\hline $8 \mathrm{c}-\mathrm{RhCl}(\mathrm{CO})_{2}$ & 63.7 & $2.109(2)$ & $1.411(3) 1.385(3)$ & $117.4(2)$ & [85] \\
\hline \multicolumn{6}{|c|}{ Transition metal complexes with the CDC $8 \mathbf{d}$} \\
\hline $8 \mathrm{~d}-\mathrm{RhCl}(\mathrm{CO})_{2}$ & & $2.123(2)$ & $1.416(3) 1.368(3)$ & $116.8(2)$ & [85] \\
\hline \multicolumn{6}{|c|}{ Transition metal complexes with the asymmetric CDC 8e } \\
\hline $\mathbf{8 e}-\mathrm{PdCl}_{2}(\mathrm{POR})_{3}$ & $\mathrm{nr}$ & $2.0398(18)$ & $1.395(3) 1.328(3)$ & $119.20(16)$ & [88] \\
\hline $8 \mathrm{e}-\mathrm{PdCl}_{2} \mathrm{PPh}_{3}$ & $\mathrm{nr}$ & $2.063(2)$ & $1.383(3) 1.409(3) \mathrm{tP}$ & $115.63(19)$ & [89] \\
\hline $8 \mathbf{e}-\mathrm{PdCl}_{2} \mathrm{PTol}_{3}$ & $\mathrm{nr}$ & $2.049(4)$ & $1.374(7) 1.412(8) \mathrm{tP}$ & 117.7(4) & [89] \\
\hline $8 \mathbf{e}-\mathrm{PdCl}_{2} \mathrm{PCy}_{3}$ & $\mathrm{nr}$ & $2.111(2)$ & $1.343(3) 1.415(4) \mathrm{tP}$ & $123.6(2)$ & [89] \\
\hline \multicolumn{6}{|c|}{ Transition metal complexes with the asymmetric CDC $8 \mathbf{f}$} \\
\hline $8 \mathrm{f}-\mathrm{RhCl}(\mathrm{CO})_{2}$ & 67.1 & $2.117(2)$ & $1.369(3) 1.424(3)$ & $117.8(2)$ & [90] \\
\hline \multicolumn{6}{|c|}{ Transition metal complexes with the asymmetric CDC $8 \mathrm{~g}$} \\
\hline $8 \mathrm{~g}-\mathrm{RhCl}(\mathrm{CO})_{2}$ & 63.2 & $2.1164(17)$ & $\begin{array}{c}1.374(2)_{\mathrm{NHC}} \\
1.420(3)\end{array}$ & $118.77(16)$ & [90] \\
\hline \multicolumn{6}{|c|}{ Transition metal complexes with the asymmetric CDC $\mathbf{8 h}$} \\
\hline $8 \mathrm{~h}-\mathrm{IrCl}(\mathrm{CO})_{2}$ & $\mathrm{nr}$ & $\mathrm{nr}$ & $\mathrm{nr}$ & $\mathrm{nr}$ & [91] \\
\hline $8 \mathbf{h}-\mathrm{IrCl}(\mathrm{cod})$ & 166.4 & $\mathrm{nr}$ & $\mathrm{nr}$ & $\mathrm{nr}$ & [91] \\
\hline
\end{tabular}


Structural parameters of the unsymmetrical CDCs (see Figure 11) are: 8e, C-C $=1.3401(16) \AA$ and 1.3455(16), C-C-C 137.55(12) ${ }^{\circ}$. For 8f, no data are available [90]. 8g: C-C = 1.344(3) $\AA$ and, 1.318(3) $\AA$, $\mathrm{C}-\mathrm{C}-\mathrm{C}=146.11(19)^{\circ}$ [90]. $8 \mathrm{~h}$ was obtained at $-60^{\circ}$ by reacting $8 \mathrm{hH}^{+}$with $\mathrm{KMDS}$, and characterized spectroscopically. On warming to room temperature, it dimerizes. ${ }^{13} \mathrm{C}$ NMR: $\delta=105.5 \mathrm{ppm}$ (see Table 8) [91].
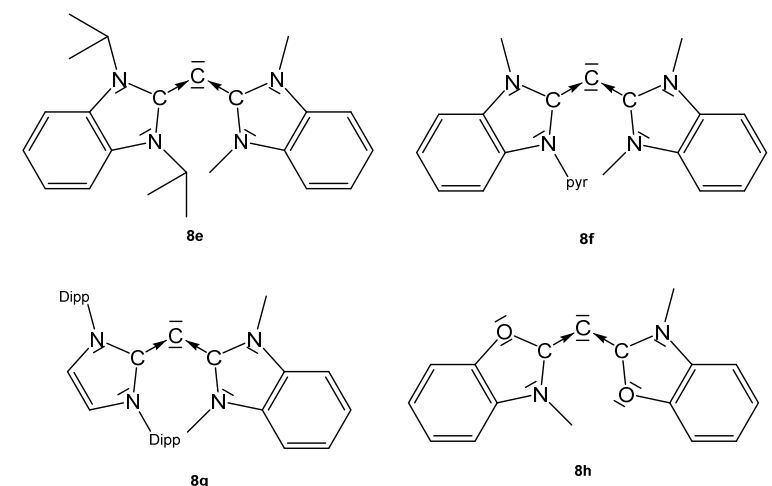

Figure 11. Unsymmetrical CDCs from which transition metal complexes are reported.

Further, $\mathbf{8 a}-\mathrm{RhCl}(\mathrm{CO})_{2}$ was prepared by addition of a suspension of $\mathbf{8 a}$ (see Scheme 16) in benzene to a solution of $\left[\mathrm{RhCl}(\mathrm{CO})_{2}\right]_{2}[83]$. $\left[8 \mathbf{b}-\mathrm{Fe}_{0.5}\right]^{2+}$ contains $\mathrm{Fe}^{2+}$ in octahedral environment coordinated by two molecules of $\mathbf{8 b}$. Fe(II) can be successively oxidized to the corresponding tri-, tetra-, and pentacationic species [87].

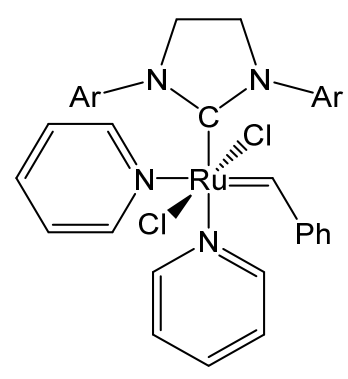

$\operatorname{Ar}=$ Mes, Dipp

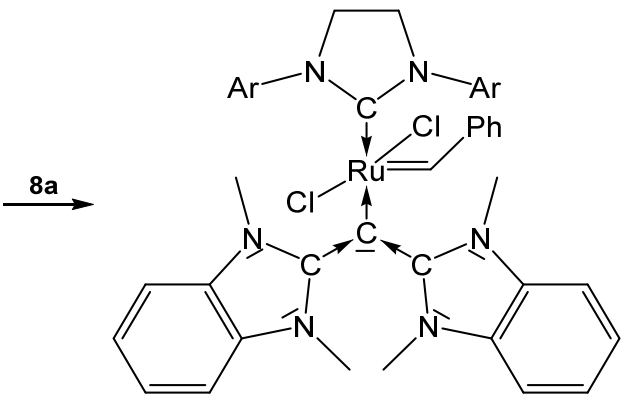

8a-RuCl ${ }_{2}=\mathrm{CHPh}-\mathrm{NHCmes}$
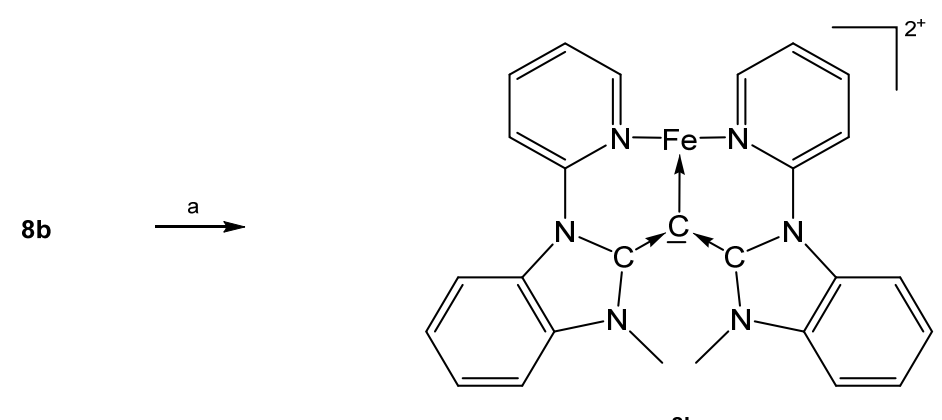

$8 b$

Scheme 16. Selected structures of transition metal complexes with symmetric CDCs $\mathbf{8 a}$ and $\mathbf{8 b}$; (a) $\mathrm{Fe}(\mathrm{OTf})_{2}(\mathrm{MeCN})_{2}$.

The addition compounds $8 \mathrm{c}-\mathrm{RhCl}(\mathrm{CO})_{2}$ and $8 \mathrm{~d}-\mathrm{RhCl}(\mathrm{CO})_{2}$ where obtained upon reacting the appropriate carbone $\mathbf{8 c}$ or $\mathbf{8 d}$ with $\left[\mathrm{RhCl}(\mathrm{CO})_{2}\right]_{2}$. Similarly, the addition of $[\mathrm{Pd}(\text { allyl }) \mathrm{Cl}]_{2}$ to $\mathbf{8 c}$ leads to the allyl complex $8 \mathrm{c}-\mathrm{PdCl}\left(\mathrm{C}_{3} \mathrm{H}_{5}\right)$ [85]. 
As depicted in Scheme 17, introduction of $\mathrm{PdCl}_{2} \mathrm{P}(\mathrm{OiPr})_{3}$ to $8 \mathbf{e}$ afforded the complex $8 \mathbf{e}-\mathrm{PdCl}_{2} \mathrm{P}(\mathrm{OiPr})_{3}$; it features a square planar Pd center with a short interatomic distance of one phosphite oxygen atom and the carbon atom of the NHC molecule of $2.890 \AA$ that is smaller than the sum of van der Waals radii. This indicates strong attractive interaction between the atoms [88]. The three $\mathrm{Pd}$ complexes $8 \mathbf{e}-\mathrm{PdCl}_{2} \mathrm{PPh}_{3}, 8 \mathbf{e}-\mathrm{PdCl}_{2} \mathrm{PTol}_{3}$, and $8 \mathbf{e}-\mathrm{PdCl}_{2} \mathrm{PCy}_{3}$ were obtained by reacting the carbone 8e with the appropriate $\mathrm{PdCl}_{2} \mathrm{PR}_{3}$; between the $\mathrm{NHC}$ and the aromatic phosphine substituents (Ph or Tol) an unexpected $\pi-\pi$ interaction was detected. One Ph and one Tol group are nearly parallel to the imidazole rings with centroid-centroid distances of $3.25 \AA$ (Ph) and $3.30 \AA$ (Tol), respectively [89].

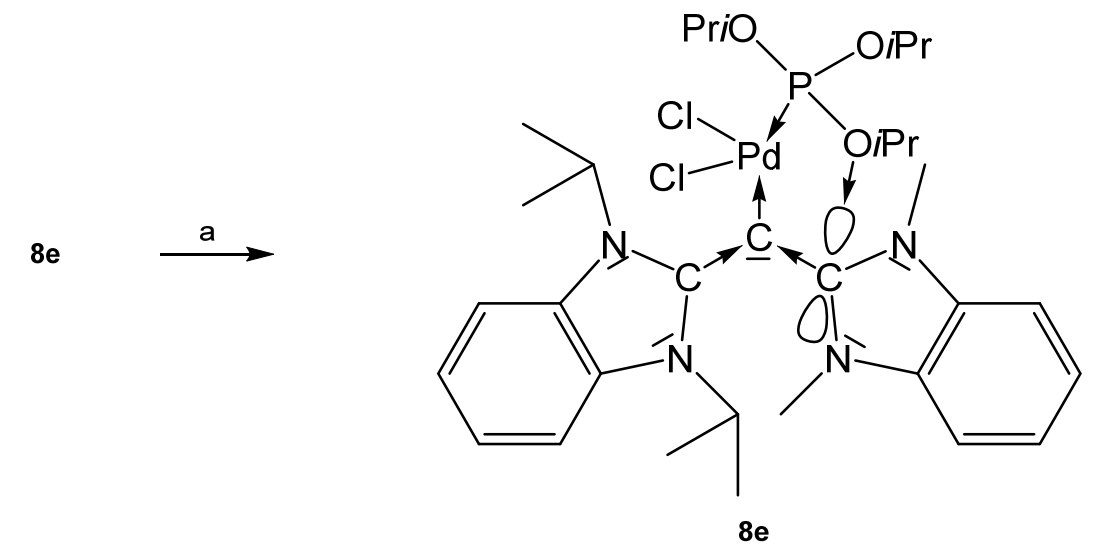

Scheme 17. Selected structural representation of $\mathbf{8 e}-\mathrm{PdCl}_{2} \mathrm{P}(\mathrm{O} i \mathrm{Pr})_{3}(\mathbf{a}) \mathrm{PdCl}_{2} \mathrm{P}(\mathrm{O} i \mathrm{Pr})_{3}$.

$\mathbf{8 f}-\mathrm{RhCl}(\mathrm{CO})_{2}$ and $\mathbf{8 g}-\mathrm{RhCl}(\mathrm{CO})_{2}$ stem from reacting the appropriate carbone with $\left[\mathrm{RhCl}(\mathrm{CO})_{2}\right]_{2}[90]$. The cod ligand of $\left[\operatorname{Ir}(\mathrm{cod}) \mathrm{Cl}_{2}\right.$ was replaced by bubbling $\mathrm{CO}$ through a mixture with $8 \mathrm{~h}$ to generate the complex 8h- $\mathrm{IrCl}(\mathrm{CO})_{2}$ [91].

Some experimental findings indicate that carbodicarbenes also have catalytic properties for a wide range of transformations, which are currently being actively studied by several groups. Examples have been reported such as hydrogenation of inert olefins [92], C-C cross-coupling reactions [84], intermolecular hydroamination [93] and hydroheteroarylation [94]. It seems that this area is still in an infant stadium and it can be expected that CDCs may be found useful as catalyst for other reactions.

\subsection{Tridentate Cyclic Diphosphino CDCs}

The carbones $\mathbf{9 a}$ and $\mathbf{9 b}$ in Figure 12 are functionalized carbodicarbene in which the donating carbon atom is part of a seven membered ring.

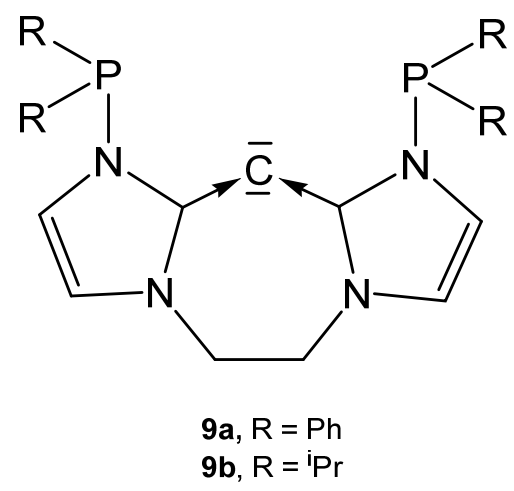

Figure 12. Hypothetical free carbones $9 \mathbf{a}$ and $\mathbf{9 b}$.

The neutral $9 \mathbf{a}$ and $\mathbf{9 b}$ could not be isolated, source for transition metal complexes are the related cations $\mathbf{9} \mathbf{a H}^{+}$and $\mathbf{9 b H} \mathbf{b}^{+}$(see Table 9) [93]. 
Table 9. Transition metal complexes with the carbones $9 a$ and $9 \mathbf{b} ;{ }^{13} \mathrm{C}$ NMR signal of the central donating carbon atom.

\begin{tabular}{|c|c|c|c|c|c|}
\hline 9-M & ${ }^{13}$ C NMR & M-C & C-C & C-C-C & Ref. \\
\hline \multicolumn{6}{|c|}{ Transition metal complexes with the carbone 9a } \\
\hline 9a-RhCl & 73.0 & $\mathrm{nr}$ & $\mathrm{nr}$ & $\mathrm{nr}$ & [93] \\
\hline$\left.{ }^{[9 a-R h N C M e}\right]^{+}$ & $\mathrm{nr}$ & 2.043 & 1.3981 .387 & $\mathrm{nr}$ & [93] \\
\hline$[9 \mathbf{a}-\mathrm{Rh}(\mathrm{CO})] \mathrm{BF}_{4}$ & $\mathrm{nr}$ & $\mathrm{nr}$ & $\mathrm{nr}$ & $\mathrm{nr}$ & [93] \\
\hline$[9 \mathrm{a}-\mathrm{Rh}$ (styrene) $] \mathrm{BF}_{4}$ & $\mathrm{nr}$ & $2.075(2)$ & $1.404(3) 1.391(3)$ & $121.7(2)$ & [94] \\
\hline$[9 \mathrm{aH}-\mathrm{Rh}(\mathrm{CO})]\left(\mathrm{BF}_{4}\right)_{2}$ & $\mathrm{nr}$ & $\mathrm{nr}$ & $\mathrm{nr}$ & $\mathrm{nr}$ & [94] \\
\hline \multicolumn{6}{|c|}{ Transition metal complexes with the carbone $\mathbf{9 b}$} \\
\hline 9b-RhCl & 73.4 & $\mathrm{nr}$ & $\mathrm{nr}$ & $\mathrm{nr}$ & [93] \\
\hline$\left[9 \mathrm{~b}-\mathrm{RhNCMe}_{\mathrm{BFF}}\right.$ & $\mathrm{nr}$ & $\mathrm{nr}$ & $\mathrm{nr}$ & $\mathrm{nr}$ & [93] \\
\hline$[9 \mathrm{~b}-\mathrm{Rh}(\mathrm{CO})] \mathrm{BF}_{4}$ & $\mathrm{nr}$ & $\mathrm{nr}$ & $\mathrm{nr}$ & $\mathrm{nr}$ & [93] \\
\hline
\end{tabular}

The neutral complexes $\mathbf{9 a}-\mathrm{RhCl}$ and $\mathbf{9 b}-\mathrm{RhCl}$ (see Scheme 18) where prepared upon reacting the cations $9 \mathrm{aH}^{+}$or $9 \mathbf{b H}^{+}$, respectively with $\left[\mathrm{Rh}(\operatorname{cod}) \mathrm{Cl}_{2} / \mathrm{NaOMe}\right.$; if treated with $\mathrm{AgBF} 4 / \mathrm{MeCN}$ the cationic spezies [9a- $\mathrm{Rh}(\mathrm{MeCN})] \mathrm{BF}_{4}$ and $[9 \mathrm{~b}-\mathrm{Rh}(\mathrm{MeCN})] \mathrm{BF}_{4}$, respectively, were isolated. The related carbonyl complexes $[9 \mathrm{a}-\mathrm{Rh}(\mathrm{CO})] \mathrm{BF}_{4}$ and $[9 \mathrm{~b}-\mathrm{Rh}(\mathrm{CO})] \mathrm{BF}_{4}$ formed similarly upon reaction with $\left[\mathrm{Rh}(\mathrm{CO})_{2} \mathrm{Cl}\right]_{2} / \mathrm{NaOMe}[93]$. The styrene complex [9a-Rh(styrene) $]^{+}$was obtained upon treating the related chloro complex with styrene/ $\mathrm{NaBAr}_{4}$; the styrene complex catalyzes the hydroarylation of dienes. Protonation of $[9 \mathrm{a}-\mathrm{Rh}(\mathrm{CO})]^{+}$with $\mathrm{HBF}_{4} \cdot \mathrm{OEt}_{2}$ generates $[\mathbf{9 a H}-\mathrm{Rh}(\mathrm{CO})]^{2+}$ in which the carbone acts as four-electron donor [94].

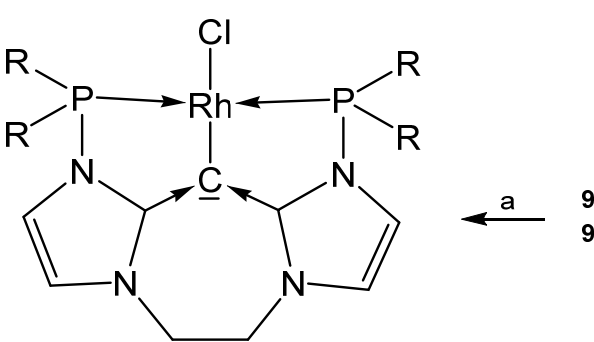

9a-RhCl, $\mathrm{R}=\mathrm{Ph}$

9b-RhCl, $\mathrm{R}={ }^{i} \mathrm{Pr}$

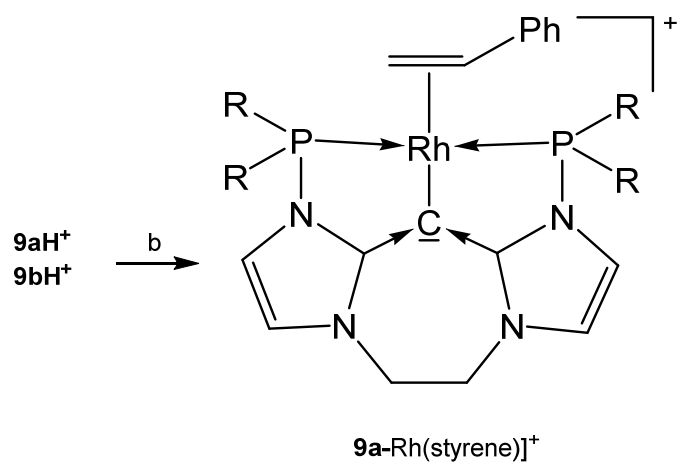

Scheme 18. Selected structures of transition metal complexes with the carbones $9 \mathbf{a}$ and $\mathbf{9 b}$.

(a) $[\mathrm{Rh}(\mathrm{cod}) \mathrm{Cl}]_{2} / \mathrm{NaOMe},(\mathbf{b}) 9 \mathrm{a}-\mathrm{RhCl} /$ styrene $/ \mathrm{NaBF}_{4}$.

\subsection{Tetraaminoallene (TAA) Transition Metal Complexes}

The ${ }^{13} \mathrm{C}$ NMR shift of the central carbon atom amounts to $142.8 \mathrm{ppm}$. The first and second PAs of 10 are 282.5 and $151.6 \mathrm{kcal} / \mathrm{mol}$, respectively [16,82].

The salt [10-AuPPh $3 \mathrm{SbF}_{6}$ in Scheme 19 is the only transition metal complex of TAA (see Figure 13), which has been reported so far. Both carbene moieties are planar, but are tilted relative to each other, to relieve allylic strain. The Au-C bond lengths amounts to 2.072(3) $\AA$ and the slightly different C-C dative bonds has interatomic distances of 1.406(5) and 1.424(5) $\AA$. The central C-C-C bond angle is reported with $118.5(3)^{\circ}$ [95]. 
10

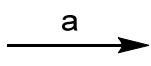

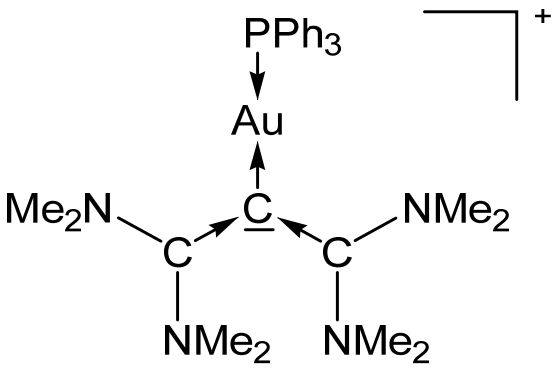

$\left[10-\mathrm{AuPPh}_{3}\right]^{+}$

Scheme 19. Preparation of $\left[\mathbf{1 0}-\mathrm{AuPPh}_{3}\right] \mathrm{SbF}_{6}$; a) $\mathrm{AuClPPh}_{3} / \mathrm{NaSbF}_{6}$.<smiles>CNC(=C=C(N(C)C)N(C)C)N(C)C</smiles><smiles>C[C@H](CN(C)C)N(C)C</smiles>

10

Figure 13. Bonding description of tetraaminoallene (TAA) (10). TAA's may have a bent geometry with hidden or masked pairs of electrons, which are delocalized but serve as double donor orbitals in complexes with $\mathrm{CO}_{2}$ and $\mathrm{CS}_{2}$ [96].

\subsection{Transition Metal Complexes of Carbones with the P-C-C Skeleton}

Mixed carbene-phosphine stabilized carbones from the working group of Bestmann (1974) and Alkarazo (2009).

The crystal structure of 11a in Figure 14 reveals a planar configuration of the carbene ligand $\mathrm{C}(\mathrm{OEt})_{2}$. Short $\mathrm{P}-\mathrm{C}$ and $\mathrm{C}-\mathrm{C}$ distances indicate some $\mathrm{p}$ back donation; $\mathrm{P}-\mathrm{C}=1.682(4) \AA, \mathrm{C}-\mathrm{C}=1.316(10)$ $\AA$, C-C-C $125.6^{\circ}$ (see Table 10) [97].<smiles>CCOC(C=Pc1ccccc1)OCC</smiles>

$11 \mathrm{a}$<smiles>CCO[C@@H](C=Pc1ccccc1)N(C)C</smiles>

$11 b$

Figure 14. In compounds 11 the $\mathrm{C}(0)$ atoms are stabilized by a phophine or a carbene ligand.

Table 10. Transition metal complexes with the mixed carbones $\mathbf{1 1 a}$ and $\mathbf{1 1 b} .{ }^{31} \mathrm{P}$ NMR shifts in ppm.

\begin{tabular}{|c|c|c|c|c|c|}
\hline 11-M & ${ }^{31}$ P NMR & M-C & P-C C-C & P-C-C & Ref. \\
\hline \multicolumn{6}{|c|}{ Transition metal complexes with the carbone 11a } \\
\hline 11a- $\mathrm{RhCl}(\mathrm{CO})_{2}$ & 25.1 & $\mathrm{nr}$ & $\mathrm{nr}$ & $\mathrm{nr}$ & [98] \\
\hline 11a-AuCl & 26.7 & $2.014(16)$ & $1.7449(16) 1.362(2)$ & $114.30(12)$ & [98] \\
\hline 11a- $(\mathrm{AuCl})_{2}$ & 28.1 & $2.081(4) 2.103(4)$ & $1.785(4) 1.425(6)$ & $114.2(3)$ & [98] \\
\hline \multicolumn{6}{|c|}{ Transition metal complexes with the carbone $\mathbf{1 1 b}$} \\
\hline 11b-AuCl & 22.2 & $\mathrm{nr}$ & $\mathrm{nr}$ & $\mathrm{nr}$ & [98] \\
\hline
\end{tabular}

The neutral Rh complex 11a- $\mathrm{RhCl}(\mathrm{CO})_{2}$ was obtained from reacting the carbone 11a with $\left[\mathrm{Rh}(\mathrm{CO})_{2} \mathrm{Cl}\right]_{2}$. Similarly, the complex $\mathbf{1 1} \mathbf{b}-\mathrm{AuCl}$ results from reaction of $\mathbf{1 1 b}$ with $\mathrm{AuCl}\left(\mathrm{SMe}_{2}\right)$ (Scheme 20) [98]. 


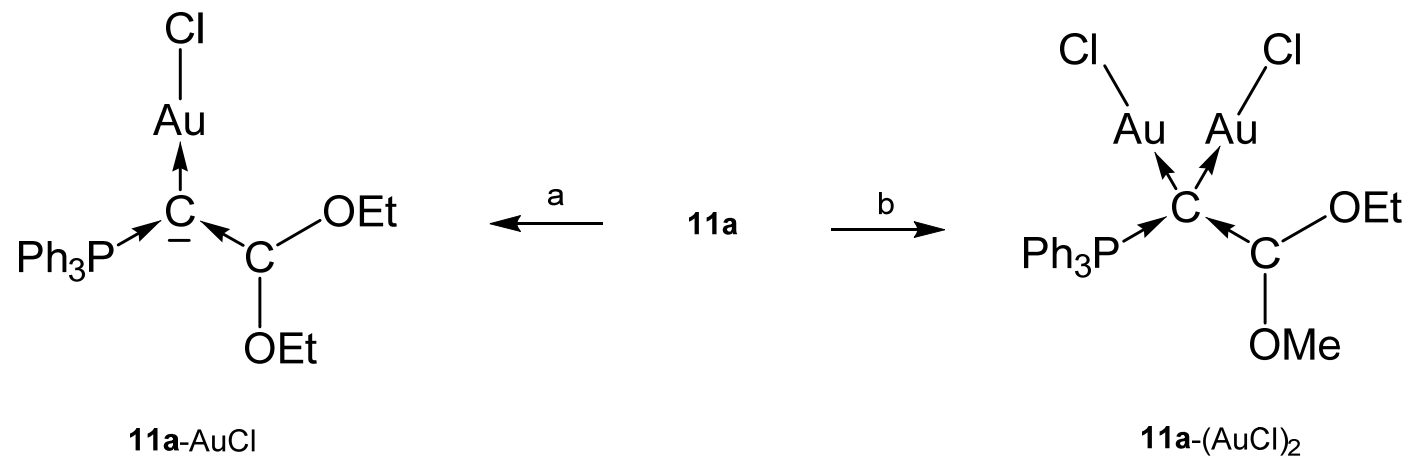

Scheme 20. Selected structural representation of transition metal complexes of 11a. (a) one equiv. of $\mathrm{AuCl}\left(\mathrm{SMe}_{2}\right)$, (b) two equiv. of $\mathrm{AuCl}\left(\mathrm{SMe}_{2}\right)$.

\subsection{Transition Metal Complexes of Carbones with the P-C-Si Skeleton}

The neutral compound $\mathbf{1 2}$ in Figure 15 is a carbone in which the $\mathrm{C}(0)$ atom is stabilized by a donor stabilized silylene and a phosphine ligand.

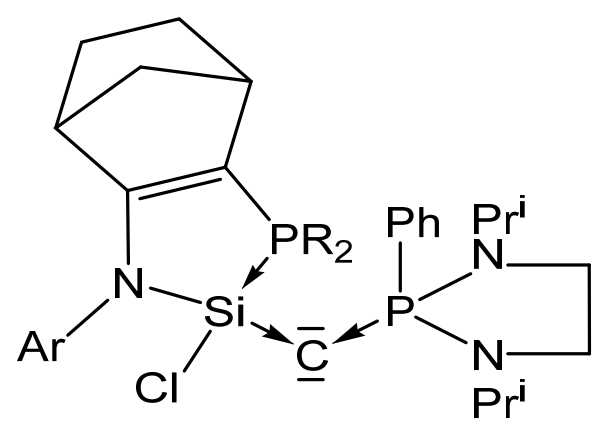

12

Figure 15. Carbone complex reported by Kato et al. [99].

The crystal structure of a related compound to 12 (a cyclopentene instead of a cyclohexene ring) shows a P-C distance of 1.6226(4) $\AA$ and Si-C distance of 1.6844(4) $\AA$; the Si-C-P angle amounts to $140.03(3)^{\circ}$.

Addition of $\mathrm{CuCl}$ generates the complex 12-CuCl. No spectroscopic or structural details are available [99].

\subsection{Transition Metal Complexes of Carbones with the P-C-S Skeleton}

A series of carbones $(\mathbf{1 3 a}, \mathbf{1 3 b})$ in Figure 16 based on a P-C-S core containing the neutral S(IV) ligands $\mathrm{SPh}_{2}=\mathrm{NMe}$ (Figure 16) were reported by Fujii [100].<smiles>CN=[Sb](P)[CH]C=P</smiles>

$13 a$<smiles>CCCCC[Sb](C=P)=NC</smiles>

13b

Figure 16. Carbone complexes reported by Fujii et al. [100].

Crystal structures and ${ }^{31} \mathrm{P}$ NMR shifts of the following basic carbones are available (see Table 11): 13a, $\delta=-2.64 \mathrm{ppm} ; 13 \mathbf{b}, \delta=-1.39 \mathrm{ppm}, \mathrm{P}-\mathrm{C}=1.663(2) \AA$, S-C $=1.602(2) \AA$, P-C-S $=125.59(15)^{\circ}$. The authors revealed a high electron density at the central carbon atom. 
Table 11. Collection of transition metal complexes with the carbones 13a and 13b. ${ }^{31} \mathrm{P}$ NMR signals (in ppm) are given.

\begin{tabular}{|c|c|c|c|c|c|}
\hline 13-M & ${ }^{31}$ P NMR & M-C & P-C S-C & P-C-S & Ref \\
\hline \multicolumn{6}{|c|}{ Transition metal complexes with the carbone $13 \mathbf{a}$ based on a P-C-S core } \\
\hline 13a-AgCl & 10.8 & 2.131 & 1.7111 .648 & 121.9 & [100] \\
\hline 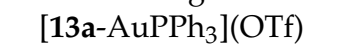 & 15.2 & $\mathrm{nr}$ & $\mathrm{nr}$ & $\mathrm{nr}$ & [100] \\
\hline$\left[13 a-\left(\mathrm{AuPPh}_{3}\right)_{2}\right](\mathrm{OTf})_{2}$ & 29.7 & $\mathrm{nr}$ & $\mathrm{nr}$ & $\mathrm{nr}$ & [100] \\
\hline \multicolumn{6}{|c|}{ Transition metal complexes with the carbone $\mathbf{1 3 b}$ based on a P-C-S core } \\
\hline 13b- $\mathrm{AgCl}$ & 9.13 & 2.098 & 1.7281 .636 & 119.1 & [100] \\
\hline$\left[13 b-\mathrm{AuPh}_{3}\right]\left(\mathrm{SbF}_{6}\right)$ & 12.88 & $\mathrm{nr}$ & $\mathrm{nr}$ & $\mathrm{nr}$ & [100] \\
\hline$\left[13 b-\left(\mathrm{AuPPh}_{3}\right)_{2}\right]\left(\mathrm{SbF}_{6}\right)_{2}$ & 27.45 & 2.1272 .118 & 1.7881 .737 & 115.6 & [100] \\
\hline$[13 b-A g-13 b][O T f)$ & 8.43 & 2.160 & 1.7071 .635 & 121.8127 .0 & [100] \\
\hline$\left[\mathbf{1 3 b H}-\mathrm{AuPPh}_{3}\right](\mathrm{OTf})_{2}$ & 17.1 & 2.106 & 1.8171 .782 & 116.3 & [100] \\
\hline
\end{tabular}

The addition products $13 a-A g C l$ and $\mathbf{1 3 b}-\mathrm{AgCl}$ were obtained from reacting $[\mathbf{1 3 a H}]^{+}$or $[\mathbf{1 3 b H}]^{+}$, respectively with ion exchange resin $\left(\mathrm{Cl}^{-}\right.$form) and $\mathrm{Ag}_{2} \mathrm{O} / \mathrm{CH}_{2} \mathrm{Cl}_{2}$. For the other products see Scheme 21 [100].

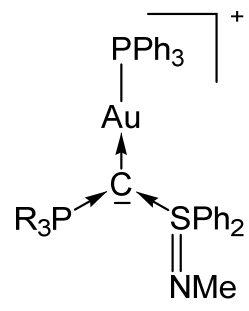

$\left[13 \mathrm{a}-\mathrm{AuPPh}_{3}\right] \mathrm{SbF}_{6}$ $\left[13 \mathrm{~b}-\mathrm{AuPPh}_{3}\right] \mathrm{SbF}_{6}$

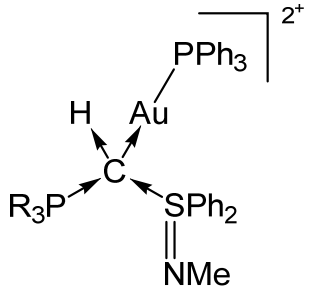

$\left[13 \mathrm{bH}-\mathrm{AuPPh}_{3}\right](\mathrm{OTf})_{2}$

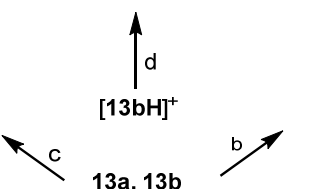

$\downarrow$

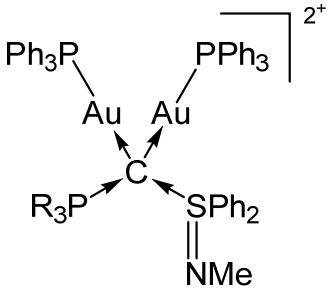

$\left[13 \mathrm{a}-\left(\mathrm{AuPPh}_{3}\right)_{2}\right]\left(\mathrm{SbF}_{6}\right)_{2}$ $\left[13 b-\left(\mathrm{AuPPh}_{3}\right)_{2}\right]\left(\mathrm{SbF}_{6}\right)_{2}$

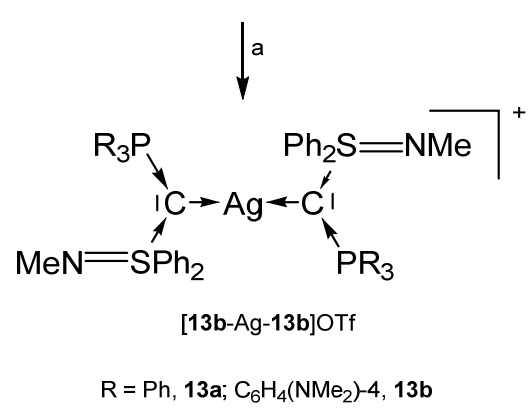

Scheme 21. Selected structures with the carbones 13a und 13b: (a) 0.5 eq. of AgOTf, (b) 2 eq. of $\mathrm{AuCl}\left(\mathrm{PPh}_{3}\right) / 2$ eq. of $\mathrm{AgSbF}_{6}$, (c) 1 eq. of $\mathrm{AuCl}\left(\mathrm{PPh}_{3}\right) / 1$ eq. of $\mathrm{AgSbF}_{6}$, (d) ion exchange $\left(\mathrm{OH}^{-}\right.$form $), 1$ eq. of $\mathrm{AuClPPh}_{3} / 1$ eq. of AgOTf [100].

Addition of TM fragments to 13a or 13b in Scheme 21 elongates P-C and S-C bond length as reported for $\mathbf{1 a}$. That of [ $\left.\mathbf{1 3} \mathbf{b H}-\mathrm{AuPPh}_{3}\right](\mathrm{OTf})_{2}$ in which $\mathbf{1 3} \mathbf{b}$ acts as four-electron donor are elongated to normal single bonds [100].

\subsection{Transition Metal Complex with a P-C-S Core Possessing a Neutral S(II) Ligand}

The carbone 14 in Figure 17 contains a phosphine and a S(II) ligand with a free pair of electrons to stabilize the $\mathrm{C}(0)$ atom. However, the bare $\mathbf{1 4}$ could not be isolated, but only the protonated cation $[\mathbf{1 4 H}]^{+}$and used as starting material [101]. 


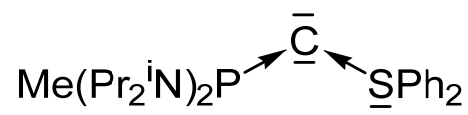

14

Figure 17. Mixed P and S stabilized carbone 14.

The transition metal complex [14-CuN(SiMe $\left.)_{2}\right](\mathrm{OTf})$ was prepared upon reacting $[\mathbf{1 4} \mathbf{H}]+$ with KHMDS/CuCl. X-ray analysis reveals a Cu-C distance of 1.903(4) $\AA$ and the P-C and S-C distances amount to $1.709(5)$ and 1.677(5) $\AA$, respectively. As found in carbone addition compounds of 13a and $\mathbf{1 3 b}$ the P-C distance is longer than the S-C distance. An acute P-C-S angle of $115.3(2)^{\circ}$ was recorded. The ${ }^{31} \mathrm{P}$ NMR signal is shifted to lower fields at $66.5 \mathrm{ppm}$ [101].

\subsection{Transition Metal Complexes of Carbones with the S-C-S Skeleton}

In the carbones 15 (carbodisulfanes, CDS) the central carbon atom is stabilized by two neutral S(II) ligands (15a), or S(II), S(IV) groups (15b), or two S(IV) (15c) ligands (see Figure 18).<smiles>[SbH2][SbH2]C=[PbH]</smiles>

$15 a$

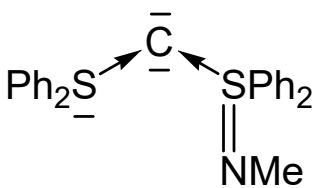

$15 b$<smiles>CN=[Sb](C)C=Cc1ccccc1</smiles>

$15 c$

Figure 18. Sulfur based carbones $\mathbf{1 5}$ as ligands for transition metal complexes.

The molecular structure of 15a was investigated computationally (see Table 12) [102]. For the carbones the following parameters were recorded: 15b, C-S ${ }^{\mathrm{II}} 1.707(2), \mathrm{C}^{-} \mathrm{S}^{\mathrm{IV}} 1.648(2)$, S-C-S 106.67(14). ${ }^{13} \mathrm{C}$ NMR, $\delta=35.4$ ppm [103]. 15c, S-C 1.635(4), 1.636(2); S-C-S 116.8(2) [104]. Similar to CDCs the first and second PAs of $\mathbf{1 5 b}$ amount to 288.0 and $184.4 \mathrm{kcal} / \mathrm{mol}$, respectively.

Table 12. Transition metal complexes with selected bond length $(\AA)$ and angles (deg) of the carbone ligands $15 a$ to $15 c .{ }^{13} \mathrm{C}$ NMR signal (in ppm) of the central carbon atom.

\begin{tabular}{|c|c|c|c|c|c|}
\hline 15-M & ${ }^{13} \mathrm{C}$ NMR & C-M & $\mathrm{S}^{\mathrm{II}}-\mathrm{C}$ & $\mathrm{S}^{\mathrm{II}}-\mathrm{M}-\mathrm{S}^{\mathrm{II}}$ & Ref. \\
\hline 15a-AgCl & not obs & $2.058(8)$ & $1.707(8) 1.698(8)$ & 107.3(5) & [102] \\
\hline$\left[\mathbf{1 5 a}-\mathrm{AuPPh}_{3}\right] \mathrm{OTf}$ & 65.4 & $\mathrm{nr}$ & $\mathrm{nr}$ & $\mathrm{nr}$ & [102] \\
\hline$\left[15 \mathbf{a}-\left(\mathrm{AuPPh}_{3}\right)_{2}\right]^{2+}$ & not obs & $2.116(6) 2.084(5)$ & $1.782(6) 1.767(6)$ & $115.4(3)$ & {$[102]$} \\
\hline \multirow[t]{2}{*}[15\mathrm{aH}-\mathrm{AuPPh}_{3}]{$^{2+}$} & 66.0 & $2.090(7)$ & $1.837(7) 1.805(7)$ & 104.4 & [102] \\
\hline & \multicolumn{4}{|c|}{ Transition metal complexes with the CDS 15b } & \\
\hline$\left[\mathbf{1 5 b}-\mathrm{AuPPh}_{3}\right] \mathrm{OTf}$ & 67.4 & $\mathrm{nr}$ & $\mathrm{nr}$ & $\mathrm{nr}$ & [102] \\
\hline$[\mathbf{1 5 b}-\mathrm{Ag}-\mathbf{1 5 b}] \mathrm{OTf}$ & not obs & $2.111(7) 2.097(7)$ & $1.718(6) 1.664(7)$ & $106.3(6)$ & {$[102,105]$} \\
\hline$\left[\mathbf{1 5 b}-\left(\mathrm{AuPPh}_{3}\right)_{2}\right](\mathrm{OTf})_{2}$ & not obs & $2.130(3) 2.103(3)$ & $1.792(3) 1.746(3)$ & $106.27(18)$ & [102] \\
\hline$\left[\mathbf{1 5 b}-\mathrm{Ag}_{2}-\mathbf{1 5 b}\right](\mathrm{OTf})_{2}$ & not obs & $\mathrm{nr}$ & $\mathrm{nr}$ & $\mathrm{nr}$ & [105] \\
\hline$\left[\mathbf{1 5 b}-\mathrm{Ag}_{4}-\mathbf{1 5 b}\right](\mathrm{OTf})_{4}$ & not obs & 2.1922 .187 & $\mathrm{nr}$ & $\mathrm{nr}$ & [105] \\
\hline \multirow[t]{3}{*}[\mathbf{15bH}-\mathrm{AuPPh}_{3}]{$(\mathrm{OTf})_{2}$} & 72.1 & $2.098(3)$ & $1.796(3) 1.789(3)$ & 106.83(17) & [102] \\
\hline & \multicolumn{4}{|c|}{ Transition metal complexes with the CDS 15c } & \\
\hline & & C-M & $S^{I V}-C$ & $S^{I V}-M-S^{I V}$ & \\
\hline$\left[15 c-\mathrm{AuPPh}_{3}\right] \mathrm{OTf}$ & 65.1 & $\mathrm{nr}$ & $\mathrm{nr}$ & $\mathrm{nr}$ & [102] \\
\hline 15c-AgCl & not obs & $2.134(3)$ & $1.690(3) 1.678(3)$ & $112.16(14)$ & [102] \\
\hline$\left[15 c-\left(\mathrm{AuPPh}_{3}\right)_{2}\right](\mathrm{OTf})_{2}$ & not obs & $2.126(4) 2.125(4)$ & $1.789(4) 1.735(5)$ & $112.5(2)$ & [102] \\
\hline [15c-Ag-15c]OTf & 40.0 & 2.1162 .127 & $1.671-1.696$ & 114.6115 .6 & [105] \\
\hline$\left[15 c-\mathrm{Ag}_{2}-15 c\right](\mathrm{OTf})_{2}$ & 43.1 & 2.147 & 1.6661 .696 & 114.7 & [105] \\
\hline$\left[15 c-\mathrm{Ag}_{4}-15 c\right](\mathrm{OTf})_{4}$ & $\mathrm{nr}$ & 2.2282 .193 & $\mathrm{nr}$ & $\mathrm{nr}$ & {$[105]$} \\
\hline$\left\{\left[15 c-\left(\mathrm{AuPPh}_{3}\right)_{2} \mathrm{AgOTf}\right](\mathrm{OTf})_{4}\right\}_{2}$ & $\mathrm{nr}$ & 2.1392 .108 & 1.7571 .747 & 116.8 & [102] \\
\hline
\end{tabular}


15a-AgCl was obtained from $[\mathbf{1 5 a H}]^{+}$upon treating with $\mathrm{Ag}_{2} \mathrm{O} / \mathrm{CH}_{2} \mathrm{Cl}_{2}$. The salt $[\mathbf{1 5 a}-\mathrm{AuPPh} 3 \mathrm{OTf}$ formed reacting the bare 15a with $\mathrm{AuCl}\left(\mathrm{PPh}_{3}\right)$ followed by addition of NaTfO in THF. [15a- $\left.\left(\mathrm{AuPPh}_{3}\right)_{2}\right]$ $(\mathrm{OTf})_{2}$ and [15aH-AuPPh 3$]\left(\mathrm{SbF}_{6}\right)$ are sketched in Scheme 22 [102].

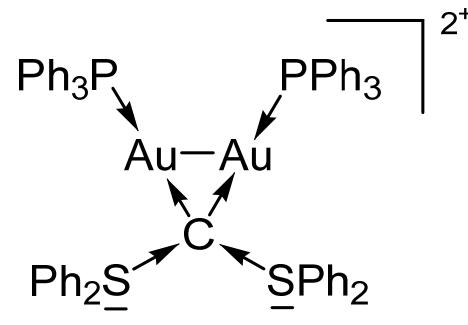

$\left[15 \mathrm{a}-\left(\mathrm{AuPPh}_{3}\right)_{2}\right](\mathrm{OTf})_{2}$

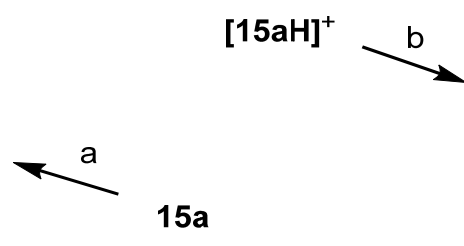

Scheme 22. Selected of complexes with the carbone 15a. (a) 2 eq $\mathrm{AuCl}\left(\mathrm{PPh}_{3}\right)$, (b) $\mathrm{AuCl}\left(\mathrm{PPh}_{3}\right)_{2}$.

[15b-AuPPh 3 ]OTf was obtained analogously formed from reacting $\mathbf{1 5 b}$ with $\mathrm{AuCl}\left(\mathrm{PPh}_{3}\right)$ followed by addition of NaTfO in THF. For the other compounds, see Scheme 23 [102].

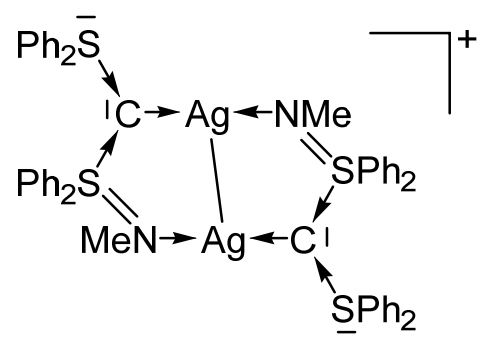

$\left.\left[15 b-\mathrm{Ag}_{2}-15 b\right](\mathrm{OTf})_{2}\right]$

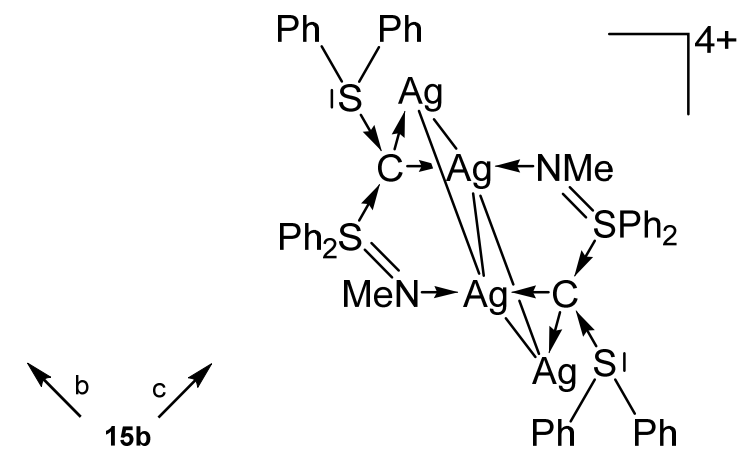

$\left.\left[15 b-\mathrm{Ag}_{4}-15 \mathrm{~b}\right](\mathrm{OTf})_{4}\right]$

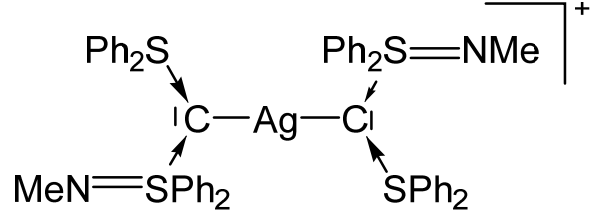

[15b-Ag-15b]OTf]


Scheme 23. Selected of complexes with the carbone 15b. (a) 0.5 eq AgOTf, (b) 1.0 eq AgOTf, (c) 2.0 eq AgOTf, (d) 2 eq $\mathrm{AuCl}\left(\mathrm{PPh}_{3}\right)$, (e) $\mathrm{AuCl}\left(\mathrm{PPh}_{3}\right)$. 
The preparation of [15c-AuPPh 3 ]OTf and $15 \mathrm{c}-\mathrm{AgCl}$ follows the procedure outlined for the related $\mathbf{1 5 b}$ compounds [102]. For the other compounds, see Scheme 24 [102,105]. The hetero hexametallic cluster $\left\{\left[\mathbf{1 5 c}-\left(\mathrm{AuPPh}_{3}\right)_{2} \mathrm{AgOTf}\right](\mathrm{OTf})_{4}\right\}_{2}$ is supported by two carbone ligands that adopt a $\kappa^{4} C, C^{\prime}, N, N^{\prime}$ coordination mode. The Au-Ag separation amounts to $3.003 \AA$ [102].
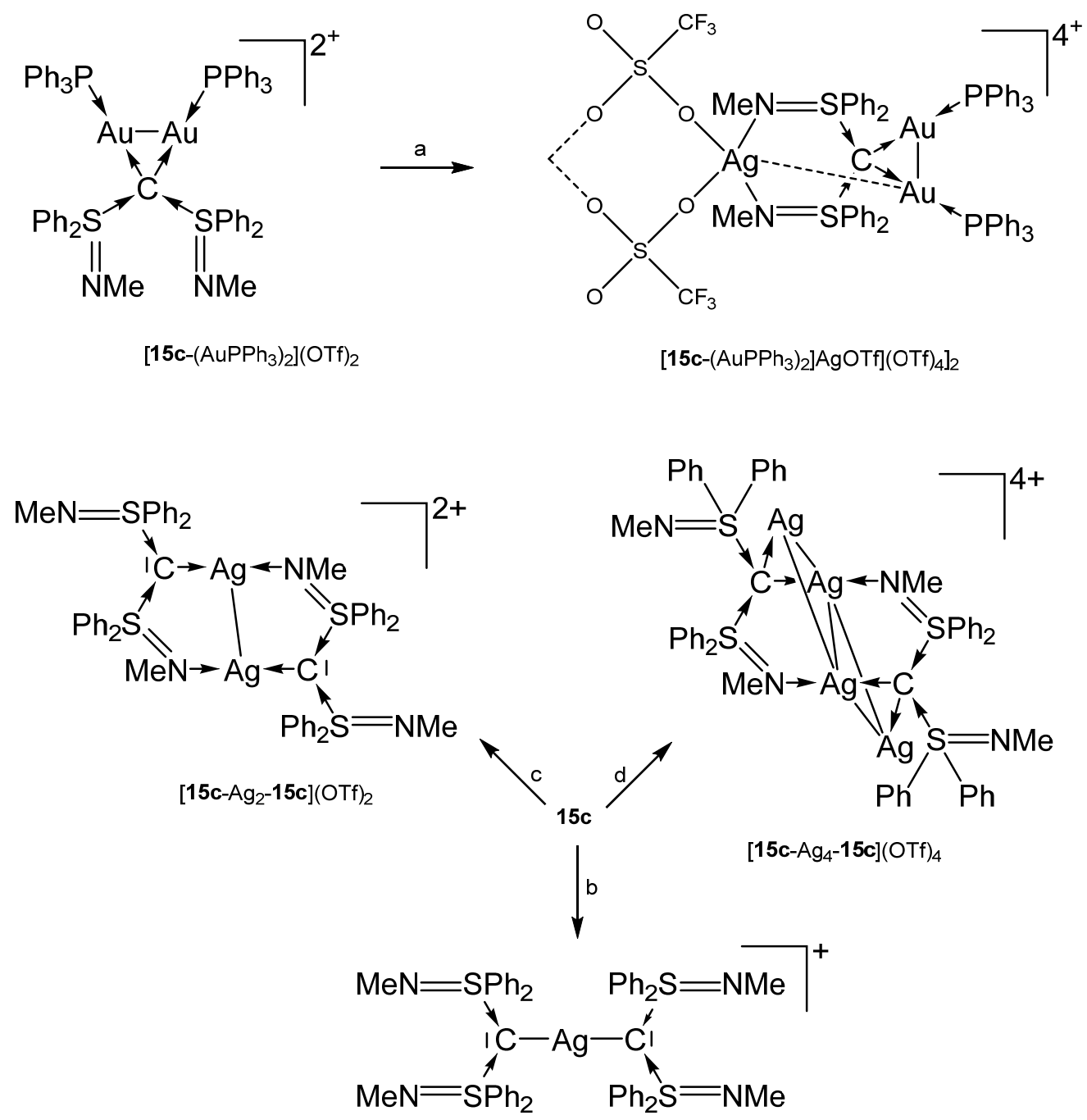

[15c-Ag-15c]OTf]

Scheme 24. Selected complexes with the carbone ligand 15c; (a) AgOTf, (b) 0.5 eq AgOTf, (c) 1.0 eq AgOTf, (d) 2.0 eq AgOTf. $\left\{\left[15 \mathrm{c}-\left(\mathrm{AuPPh}_{3}\right)_{2} \mathrm{AgOTf}\right](\mathrm{OTf})_{4}\right\}_{2}$ is dimeric linked by two OTf anions.

${ }^{13} \mathrm{C}$ NMR signals of the donating $\mathrm{C}(0)$ atoms (if available) of all addition compounds of $15 \mathrm{a}$ to $15 \mathrm{c}$ are less shielded than that of the basic carbones [102].

\subsection{Transition Metal Complexes of Carbones with the S-C-Se Skeleton (16)}

Compound $\mathbf{1 6}$ in Figure 19 is the first carbone containing a Se(II) compound together with a S(IV) one as ligand for stabilization of a $\mathrm{C}(0)$ atom. 


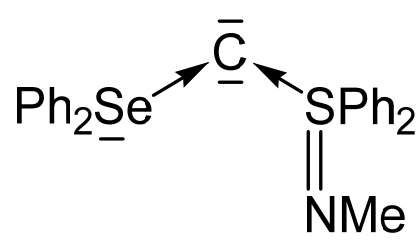

16

Figure 19. Carbone with Se and S based ligands L.

The tetranuclear complex $\left[\mathbf{1 6}-\mathrm{Ag}_{4}-\mathbf{1 6}\right]^{4+}$ contains a rhomboidal $\left[\mathrm{Ag}_{4}\right]^{4+}$ core surrounded by two carbones 16 (see Table 13). In this and in $[\mathbf{1 6 H}-\mathrm{Ag}-\mathbf{1 6 H}]^{3+}$ the donating $\mathrm{C}(0)$ acts as a four-electron donor (see Scheme 25) [105].

Table 13. Transition metal complexes with selected bond length $(\AA)$ and angles (deg) of the carbone 16.

${ }^{13} \mathrm{C}$ NMR signal (in ppm) of the central carbon atom.

\begin{tabular}{cccccc}
\hline $\mathbf{1 6}-\mathbf{M}$ & ${ }^{\mathbf{1 3}} \mathbf{C}$ NMR & C-M & C-S C-Se & S-C-Se & Ref. \\
\hline$[\mathbf{1 6}-\mathrm{Ag}-\mathbf{1 6}](\mathrm{OTf})$ & not obs. & $\mathrm{nr}$ & $\mathrm{nr}$ & $\mathrm{nr}$ & {$[105]$} \\
{$\left[\mathbf{1 6}-\mathrm{Ag}_{2} \mathbf{- 1 6}\right](\mathrm{OTf})_{2}$} & 52.7 & $\mathrm{nr}$ & $\mathrm{nr}$ & $\mathrm{nr}$ & {$[105]$} \\
{$\left[\mathbf{1 6}-\mathrm{Ag}_{4}-\mathbf{1 6}\right](\mathrm{OTf})_{4}$} & not obs & $2.174(5)$ & $1.714(5)$ & $106.4(3)$ & {$[105]$} \\
& & $2.164(4)$ & $1.772(5) 1.771(5)$ & $103.8(2)$ & {$[103]$} \\
\hline $\mathbf{1 6 H}-\mathrm{Ag}-\mathbf{1 6 H}]\left(\mathrm{BF}_{4}\right)_{3}$ & not obs & $2.177(4)$ & $1.936(4) 1.948(5)$ & & \\
\hline
\end{tabular}

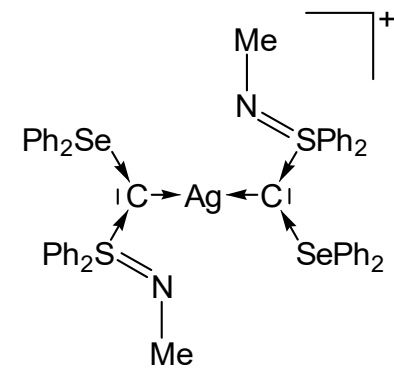

$[16-\mathrm{Ag}-16](\mathrm{OTf})$

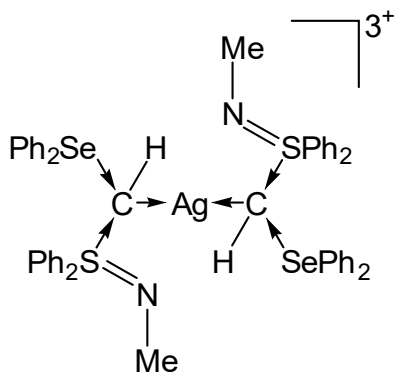

$[16 \mathrm{H}-\mathrm{Ag}-16 \mathrm{H}]\left(\mathrm{BF}_{4}\right)_{3}$<smiles>C[C+](C)C</smiles>

16

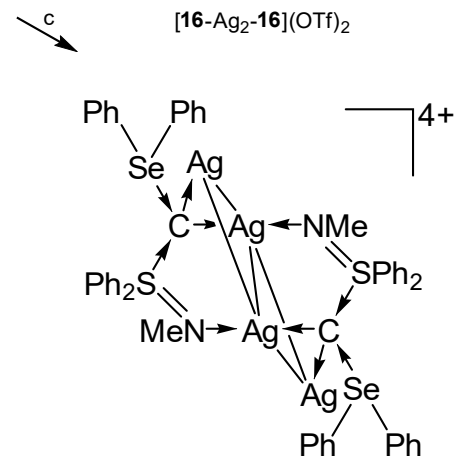

[16-Ag4-16](OTf) 4

Scheme 25. Transition metal complexes with the carbone $\mathbf{1 6}$ as two and four electron donor. (a) 0.5 eq AgOTf, (b) 1 eq AgOTf, (c) 2.0 eq AgOTf, (d) $\mathrm{AgBF}_{4} / \mathrm{CH}_{2} \mathrm{Cl}_{2}$.

\section{Transition Metal Carbido Complexes [M]-C}

The second part of this review summarizes the research of transition metal complexes with a naked carbon atom as ligand [M]-C. They are often termed as carbides, but the bonding situation is clearly different from well-known carbides of the alkaline and alkaline earth elements $\mathrm{E}$, which are salt compounds of acetylene $E_{n} C_{2}$. The electron configuration of carbon atom in the ${ }^{1} \mathrm{D}$ state 
$\left(2 s^{2} 2 p_{x}{ }^{2} 2 p_{y}{ }^{0} 2 p_{z}{ }^{0}\right)$ is perfectly suited for dative bonding with a transition metal following the DCD model [7] in terms of $\sigma$ donation and $\pi$ backdonation [M] $\rightleftarrows$ Cl. Carbon complexes [M]-C may thus be considered as carbone complexes $[\mathrm{M}]-\mathrm{CL}_{2}$ without the ligands $\mathrm{L}$ at the carbon atoms. A theoretical study showed in 2000 that the 18 valence electron $(\mathrm{VE})$ complex $\left[(\mathrm{CO})_{4} \mathrm{Fe}(\mathrm{C})\right]$ is an energy minimum structure with a rather strong Fe-C bond [106]. However, such 18 VE systems could not be synthesized as isolated species but were only found as ligands where the lone-pair electron at the carbon atom serves as donor (see below). It seems that the electron lone-pair at carbon in the $18 \mathrm{VE}$ complexes $[\mathrm{M}]-\mathrm{C}$ makes the adducts too reactive to become isolated.

It came as a surprise when Heppert and co-workers reported in 2002 the first neutral adducts with a naked carbon atom as a ligand, which are the formally $16 \mathrm{VE}$ diamagnetic ruthenium complexes [( $\left.\left.\mathrm{PCy}_{3}\right) \mathrm{LCl}_{2} \mathrm{Ru}(\mathrm{C})\right]$ ( $\mathrm{L}=\mathrm{PCy}$ and 1,3-dimesityl-4,5-dihydroimidazol-2-ylidene; $\mathrm{Cy}=$ Cyclohexyl) [27]. A subsequent bonding analysis of the model compound $\left[\left(\mathrm{Me}_{3} \mathrm{P}\right)_{2} \mathrm{Cl}_{2} \mathrm{Ru}-\mathrm{C}\right]$ considered five different models A-E for the Ru-C bonds that are shown in Figure 20 [28]. It turned out that the best description for the bonding interactions is a combination of electron-sharing and dative bonds. An energy decomposition analysis [107] suggested that the model $\mathrm{B}$ provides the most faithful account of the bond, where the $\sigma$ bond and the $\pi$ bond in the $\mathrm{Cl}_{2} \mathrm{M}$ plane come from electron-sharing interactions $\mathrm{Cl}_{2} \mathrm{M}=\mathrm{C}$ whereas the $\pi$ bond in the $\mathrm{P}_{2} \mathrm{M}$ plane is due to backdonation $\left(\mathrm{Me}_{3} \mathrm{P}\right)_{2} \mathrm{Ru} \rightarrow \mathrm{C}$. The compounds $\left[\left(\mathrm{PCy}_{3}\right) \mathrm{LCl}_{2} \mathrm{Ru}(\mathrm{C})\right]$ should therefore be considered as $18 \mathrm{VE} \mathrm{Ru}(\mathrm{IV})$ adducts. The following section summarizes the research of transition metal complexes with a naked carbon atom as ligand [M]-C that has been accomplished since 2002.

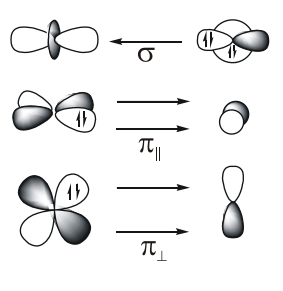

TM

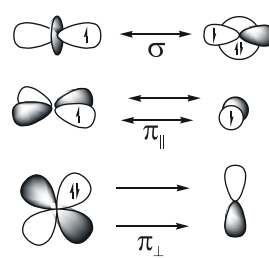

TM

B
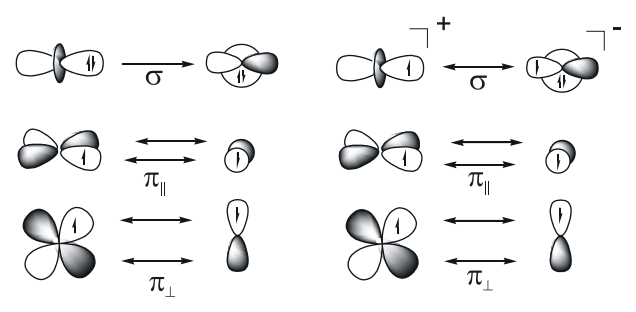

$\mathrm{TM}$

A

D
$\mathrm{C}\left({ }^{3} \mathrm{P}\right)$

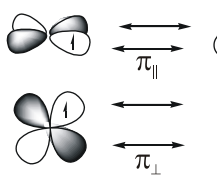

$\mathrm{TM}^{+}$

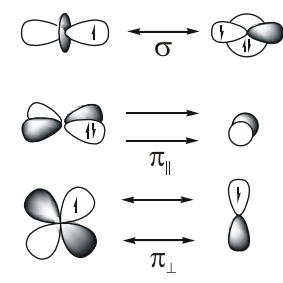

TM $\mathrm{C}\left({ }^{3} \mathrm{P}\right)$ C

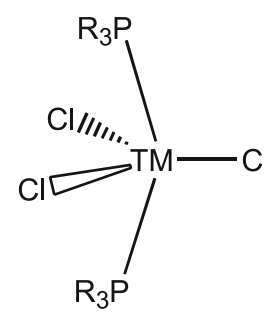

Figure 20. Bonding models (A-E) for the bonding between a transition metal (TM) and a naked carbon atom in the compound $\left[\left(\mathrm{R}_{3} \mathrm{P}\right)_{2} \mathrm{Cl}_{2} \mathrm{Ru}-\mathrm{C}\right]$.

\subsection{The System $\mathrm{RuCl}_{2}\left(\mathrm{PCy}_{3}\right)_{2} \mathrm{C}([\mathrm{Ru}] \mathrm{C})$}

By far the most known complexes with carbido ligands that have been synthesized and structurally characterized are ruthenium adducts. The progress in the chemistry of ruthenium carbido complexes was reviewed in 2012 by Takemoto and Matsuzaka [108]. In the following, we summarize the present knowledge on ruthenium carbido complexes which has been reported in the literature.

The X-ray analysis of [Ru]C in Figure 21 exhibits a Ru-C distance of 1.632(6) $\AA$. A signal at $471.8 \mathrm{ppm}$ was attributed to the ligand carbon atom [109]. A general route to carbon complexes is described in [110]. 


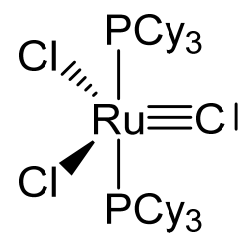

$[\mathrm{Ru}] \mathrm{C}$

Figure 21. The $[\mathrm{Ru}] \mathrm{C}$ core.

Addition of $\mathrm{PdCl}_{2}\left(\mathrm{SMe}_{2}\right)_{2}$ gives the complex $[\mathrm{Ru}] \mathrm{C} \rightarrow \mathrm{PdCl}_{2}\left(\mathrm{SMe}_{2}\right)$, while with $\mathrm{Mo}(\mathrm{CO})_{5}\left(\mathrm{NMe}_{3}\right)$ the carbonyl complex $[\mathrm{Ru}] \mathrm{C} \rightarrow \mathrm{Mo}(\mathrm{CO})_{5}$ is generated (see Table 14) $[29,109]$. A series of $[\mathrm{Ru}] \mathrm{C} \rightarrow \mathrm{PtCl}_{2} \mathrm{~L}$ complexes were obtained by Bendix from reacting the dimeric complex $\left\{[\mathrm{Ru}] \mathrm{C} \rightarrow \mathrm{PtCl}_{2}\right]_{2}$ with various ligands $\mathrm{L}\left(\mathrm{L}=\mathrm{PPh}_{3}, \mathrm{PCy}_{3}, \mathrm{P}(\mathrm{OPh})_{3}, \mathrm{AsPh}_{3}, \mathrm{CN}^{t} \mathrm{Bu}, \mathrm{CNCy}\right)$. Complexes with bridging ligands $\mathrm{L}$ such as $\left\{[\mathrm{Ru}] \mathrm{C} \rightarrow \mathrm{PtCl}_{2}\right]_{2}$ bipy, $\left\{[\mathrm{Ru}] \mathrm{C} \rightarrow \mathrm{PtCl}_{2}\right]_{2}$ pyz, and $\left\{[\mathrm{Ru}] \mathrm{C} \rightarrow \mathrm{PtCl}_{2}\right]_{2}$ pym formed upon displacing ethylene from the related $\left(\mathrm{C}_{2} \mathrm{H}_{4}\right) \mathrm{PtCl}_{2}-\mathrm{L}-\mathrm{PtCl}_{2}\left(\mathrm{C}_{2} \mathrm{H}_{4}\right)$ by $[\mathrm{Ru}] \mathrm{C}$. $\{[\mathrm{Ru}] \mathrm{C} \rightarrow \mathrm{PtCl}]_{2}(\mu-\mathrm{Cl}) \mathrm{pz}$ results from an ethylene complex and $[\mathrm{Ru}] \mathrm{C}$ as depicted in Scheme 26 [111]. A series of $\mathrm{Pt}, \mathrm{Pd}, \mathrm{Rh}, \mathrm{Ir}, \mathrm{Ag}, \mathrm{Ru}$ complexes were presented by Bendix with X-ray data and ${ }^{13} \mathrm{C}$ NMR shifts of the ligand carbon atom ranging between 340 and 412 ppm [112]. Sulfur containing TM complexes with the metals $\mathrm{Pd}, \mathrm{Pt}, \mathrm{Au}$, and $\mathrm{Cu}$ stem from the same laboratory. The sulfur ligands are $\mathrm{ttcn}=1,4,7$-trithiacyclononane and $\mathrm{S}_{4}\left(\mathrm{MCp}^{*}\right)_{3}$ (see Figure 22) [113].

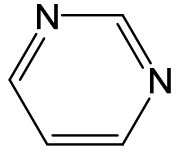

pym

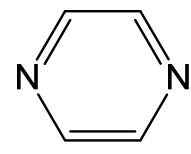

pyz

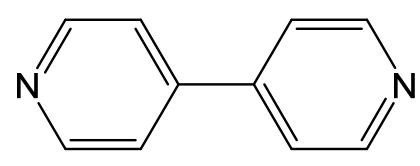

bipy

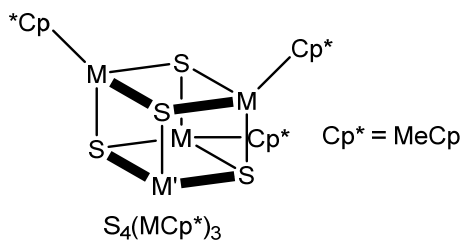

Figure 22. Spezification of ligands of Table 14.

Table 14. Selected structural (in $\AA$ and deg) and spectroscopic $\left({ }^{13} \mathrm{C}\right.$ NMR in ppm) details of [Ru]C addition compounds.

\begin{tabular}{|c|c|c|c|c|c|}
\hline & ${ }^{13} \mathrm{C}$ NMR & Ru-C & $\mathrm{M}-\mathrm{C}$ & Ru-C-M & Ref \\
\hline$[\mathrm{Ru}] \mathrm{C} \rightarrow \mathrm{PdCl}_{2}\left(\mathrm{SMe}_{2}\right)$ & 381.23 & $1.662(2)$ & $1.946(2)$ & 175.1(1) & [109] \\
\hline$\left\{[\mathrm{Ru}] \mathrm{C} \rightarrow \mathrm{PdCl}_{3}\right\}^{-}$ & 380.9 & $\mathrm{nr}$ & $\mathrm{nr}$ & $\mathrm{nr}$ & [112] \\
\hline$[\mathrm{Ru}] \mathrm{C} \rightarrow \mathrm{Mo}(\mathrm{CO})_{5}$ & 446.31 & $\mathrm{nr}$ & $\mathrm{nr}$ & $\mathrm{nr}$ & [109] \\
\hline$[\mathrm{Ru}] \mathrm{C} \rightarrow \mathrm{PtCl}_{2} \mathrm{Py}$ & 350.34 & $\mathrm{nr}$ & $\mathrm{nr}$ & $\mathrm{nr}$ & {$[29,111]$} \\
\hline$[\mathrm{Ru}] \mathrm{C} \rightarrow \mathrm{PtCl}_{2} \mathrm{NCr}(\mathrm{dbm})_{2}$ & $\mathrm{nr}$ & $1.676(2)$ & $1.899(2)$ & $174.5(1)$ & [29] \\
\hline$\left\{[\mathrm{Ru}] \mathrm{C} \rightarrow \mathrm{PtCl}_{3}\right\}^{-}$ & 344.7 & $\mathrm{nr}$ & $\mathrm{nr}$ & $\mathrm{nr}$ & {$[29,112]$} \\
\hline$\left\{[\mathrm{Ru}] \mathrm{C} \rightarrow \mathrm{PtCl}_{2}\right\}_{2}$ & 326.23 & $1.676(8)$ & $1.871(8)$ & $1796(4)$ & {$[29,111]$} \\
\hline$[\mathrm{Ru}] \mathrm{C} \rightarrow \mathrm{PtCl}_{2} \mathrm{PPh}_{3}$ & 388.81 & $1672(2)$ & $1.983(2)$ & 173.7(1) & [111] \\
\hline$[\mathrm{Ru}] \mathrm{C} \rightarrow \mathrm{PtCl}_{2} \mathrm{P}(\mathrm{OPh})_{3}$ & 387.54 & $1.659(2)$ & $2.001(2)$ & $179.3(2)$ & [111] \\
\hline$[\mathrm{Ru}] \mathrm{C} \rightarrow \mathrm{PtCl}_{2} \mathrm{AsPh}_{3}$ & 374.68 & $1.670(2)$ & $1.949(2)$ & $171.9(2)$ & [111] \\
\hline$[\mathrm{Ru}] \mathrm{C} \rightarrow \mathrm{PtCl}_{2} \mathrm{CN}^{\mathrm{t}} \mathrm{Bu}$ & 376.26 & $1.661(2)$ & $1.967(6)$ & $176.5(3)$ & [111] \\
\hline$[\mathrm{Ru}] \mathrm{C} \rightarrow \mathrm{PtCl}_{2} \mathrm{CNCy}$ & 376.04 & $\mathrm{nr}$ & $\mathrm{nr}$ & $\mathrm{nr}$ & [111] \\
\hline$[\mathrm{Ru}] \mathrm{C} \rightarrow \mathrm{PtCl}_{2} \mathrm{PCy}_{3}$ & 396.77 & $1.666(3)$ & $1.971(2)$ & $174.5(2)$ & [111] \\
\hline$[\mathrm{Ru}] \mathrm{C} \rightarrow \mathrm{PtCl}_{2}(\mathrm{dmso})$ & 349.0 & & & & [112] \\
\hline$\left\{[\mathrm{Ru}] \mathrm{C} \rightarrow \mathrm{PtCl}_{2}\right\}_{2}$ bipy & 348.27 & $1.679(3)$ & $1.891(4)$ & $171.4(2)$ & [111] \\
\hline$\left\{[\mathrm{Ru}] \mathrm{C} \rightarrow \mathrm{PtCl}_{2}\right\}_{2}$ pyz & 342.48 & $1.668(6)$ & $1.895(6)$ & 176.3(3) & [111] \\
\hline
\end{tabular}


Table 14. Cont.

\begin{tabular}{|c|c|c|c|c|c|}
\hline & ${ }^{13}$ C NMR & $\mathrm{Ru}-\mathrm{C}$ & M-C & Ru-C-M & Ref \\
\hline$\left\{[\mathrm{Ru}] \mathrm{C} \rightarrow \mathrm{PtCl}_{2}\right\}_{2} \mathrm{pym}$ & 341.36 & $1.678(3)$ & $1.893(3)$ & $176.0(2)$ & [111] \\
\hline$\left\{[\mathrm{Ru}] \mathrm{C} \rightarrow \mathrm{PtCl}_{2}(\mu-\mathrm{Cl}) \mathrm{pz}\right.$ & 355.09 & $1.678(4)$ & $1.909(4)$ & $169.9(2)$ & [111] \\
\hline$[\mathrm{Ru}] \mathrm{C} \rightarrow \mathrm{AuCl}$ & 395.3 & $\mathrm{nr}$ & $\mathrm{nr}$ & $\mathrm{nr}$ & [112] \\
\hline$\{[\mathrm{Ru}] \mathrm{C} \rightarrow \mathrm{Au} \leftarrow \mathrm{C}[\mathrm{Ru}]\}^{+}$ & 395.3 & $\mathrm{nr}$ & $\mathrm{nr}$ & $\mathrm{nr}$ & [112] \\
\hline$\{[\mathrm{Ru}] \mathrm{C} \rightarrow \operatorname{IrCl}(\mathrm{CO}) \leftarrow \mathrm{C}[\mathrm{Ru}]\}$ & 397.4 & $\mathrm{nr}$ & $\mathrm{nr}$ & $\mathrm{nr}$ & [112] \\
\hline$\{[\mathrm{Ru}] \mathrm{C} \rightarrow \mathrm{Rh}(\mathrm{CO})\}_{2}(\mu-\mathrm{Cl})_{2}$ & 396.4 & $\mathrm{nr}$ & $\mathrm{nr}$ & $\mathrm{nr}$ & [112] \\
\hline$[\mathrm{Ru}] \mathrm{C} \rightarrow \mathrm{RhCl}(\mathrm{cod})$ & 411.7 & $\mathrm{nr}$ & $\mathrm{nr}$ & $\mathrm{nr}$ & [112] \\
\hline$[\mathrm{Ru}] \mathrm{C} \rightarrow \operatorname{IrCl}(\mathrm{cod})$ & 387.6 & $\mathrm{nr}$ & $\mathrm{nr}$ & $\mathrm{nr}$ & [112] \\
\hline$\left\{[\mathrm{Ru}] \mathrm{C} \rightarrow \mathrm{Ag}\left(4^{\prime}-\mathrm{H}\right.\right.$-terpy $\left.)\right\}$ & 433.5 & $\mathrm{nr}$ & $\mathrm{nr}$ & $\mathrm{nr}$ & [112] \\
\hline$\left\{[\mathrm{Ru}] \mathrm{C} \rightarrow \operatorname{Ag}\left(4^{\prime}-\mathrm{Ph}\right.\right.$-terpy $\left.)\right\}$ & 433.1 & $\mathrm{nr}$ & $\mathrm{nr}$ & $\mathrm{nr}$ & [112] \\
\hline$[\mathrm{Ru}] \mathrm{C} \rightarrow \operatorname{Ag}(\mathrm{ttcn})$ & $\mathrm{nr}$ & $1.653(4)$ & $1.876(4)$ & $177.3(2)$ & [112] \\
\hline$[\mathrm{Ru}] \mathrm{C} \rightarrow \mathrm{Cu}(\mathrm{ttcn})$ & $\mathrm{nr}$ & $1.622(7)$ & $2.098(7)$ & $176.9(5)$ & [112] \\
\hline$[\mathrm{Ru}] \mathrm{C} \rightarrow \mathrm{Pd}-\mathrm{S}_{4}\left(\mathrm{MoCp}^{*}\right)_{3}$ & $\mathrm{nr}$ & $1.672(3)$ & 1.971(3 & $178.3(2)$ & [112] \\
\hline$[\mathrm{Ru}] \mathrm{C} \rightarrow \mathrm{Pt}-\mathrm{S}_{4}\left(\mathrm{MoCp}^{*}\right)_{3}$ & $\mathrm{nr}$ & $1.689(7)$ & $1.896(7)$ & $178.2(5)$ & [112] \\
\hline$[\mathrm{Ru}] \mathrm{C} \rightarrow \mathrm{Pd}-\mathrm{S}_{4}\left(\mathrm{WCP}^{*}\right)_{3}$ & $\mathrm{nr}$ & $1.668(5)$ & $1.959(5)$ & $178.1(3)$ & [112] \\
\hline$[\mathrm{Ru}] \mathrm{C} \rightarrow \mathrm{Pt}^{-\mathrm{S}_{4}}\left(\mathrm{WCp}^{*}\right)_{3}$ & $\mathrm{nr}$ & $1.699(9)$ & $1.874(9)$ & $178.8(6)$ & [112] \\
\hline
\end{tabular}<smiles>C[As](Cl)(Cl)[Pb](Cl)(Cl)C#CP(C)(C)(P)Cl</smiles>

$[\mathrm{Ru}] \mathrm{C}-\mathrm{PdCl}_{2}\left(\mathrm{SMe}_{2}\right)$<smiles></smiles>

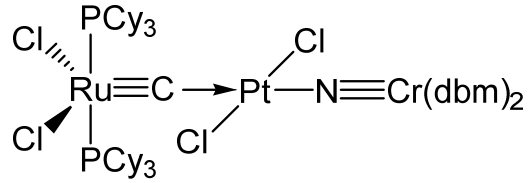

$\left.[\mathrm{Ru}] \mathrm{C}-\mathrm{PtCl} \mathrm{NCr}_{2} \mathrm{NCdbm}\right)_{2}$

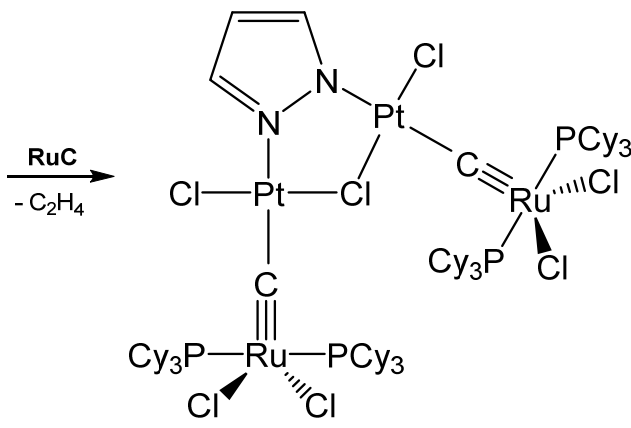

$\{[\mathrm{Ru}] \mathrm{C}-\mathrm{PtCl}\}_{2}(\mu-\mathrm{Cl}) \mathrm{pz}$

Scheme 26. Selected $[\mathrm{Ru}] \mathrm{C} \rightarrow \mathrm{M}$ carbido complexes and synthesis of $\left\{[\mathrm{Ru}] \mathrm{C} \rightarrow \mathrm{PtCl}_{2}(\mu-\mathrm{Cl}) \mathrm{pz}\right.$.

\subsection{The System $\mathrm{RuCl}_{2}\left(\mathrm{PC}_{3}\right)(\mathrm{NHC}) \mathrm{C}\left({ }^{\mathrm{NHC}}[\mathrm{Ru}] \mathrm{C}\right)$}

The X-ray analysis of ${ }^{\mathrm{NHC}}[\mathrm{Ru}] \mathrm{C}$ in Figure 23 exhibits a Ru-C distance of 1.605(2) $\AA$. A signal at $471.5 \mathrm{ppm}$ was attributed to the ligand carbon atom. No addition compounds were described so far [27].

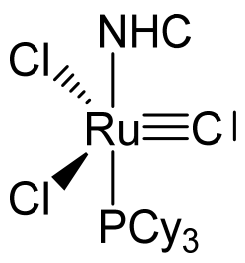

$\mathrm{NHC}=$<smiles>CS(=O)(=O)N1CCN(S(C)(=O)=O)C1</smiles>

$\mathrm{NHC}_{[\mathrm{Ru}] \mathrm{C}}$

Figure 23. The ${ }^{\mathrm{NHC}}[\mathrm{Ru}] \mathrm{C}$ core. 


\subsection{The System (NHC) $\mathrm{Cl}_{3} \mathrm{RuC}^{-}\left({ }^{\mathrm{NHC}}[\mathrm{Ru}]^{-} \mathrm{C}\right)$}

Treating the carbene complex $(\mathrm{NHC}) \mathrm{Cl}_{2}\left(\mathrm{PCy}_{3}\right) \mathrm{Ru}=\mathrm{CH}_{2}$ in Figure 24 at $55^{\circ}$ in benzene generated the neutral complex depicted in Figure 25. X-ray analysis revealed a Ru${ }^{1}-C$ distance of 1.698(4) $\AA$ and the $\mathrm{Ru}^{2}-\mathrm{C}$ distance of $1.875(4) \AA$ with a Ru-C-Ru angle of $160.3(2)^{\circ}$. In the ${ }^{13} \mathrm{C}$ NMR the bridging $\mathrm{C}$ atom resonates at the typical value of $414.0 \mathrm{ppm}$ [114].<smiles>CCN[R](Cl)(Cl)CC</smiles>

Figure 24. The ${ }^{\mathrm{NHC}}\left[\mathrm{RuCl}_{3}\right]^{-} \mathrm{C}$ core.

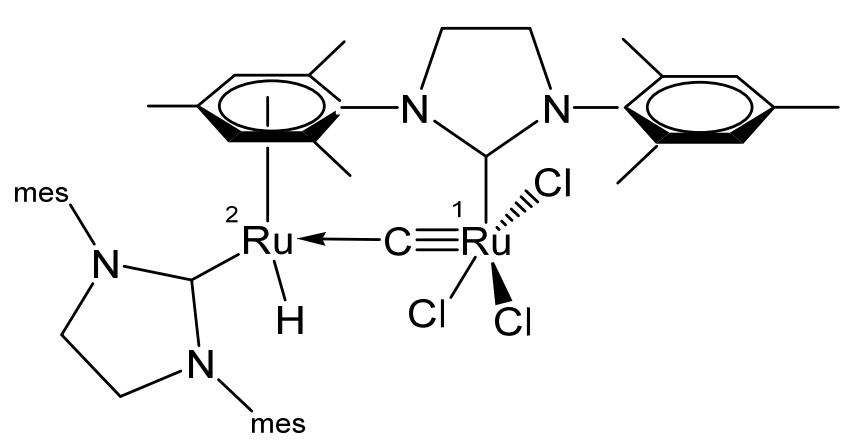

Figure 25. Structural representation of the Ru carbido complex $\mathrm{Ru}_{2}(\mathrm{NHC})_{2}(\equiv \mathrm{C}) \mathrm{Cl}_{3} \mathrm{H}$.

\subsection{The system $\mathrm{RuClX}\left(P C y_{3}\right)_{2} \mathrm{C}([\mathrm{Ru}] \mathrm{XC})$}

Various carbido complexes were reported in which one or both chloride ions in [Ru]C are replaced by $X(X=B r, I, C N, N C O, N C S)$ (see Figure 26$).\{[R u](M e C N) C\} O T f$ is the first cationic carbido complex which is also starting point for most of the substituted carbido complexes. X-ray data for $\{[\mathrm{Ru}](\mathrm{MeCN}) \mathrm{C}\} \mathrm{OTf},[\mathrm{Ru}](\mathrm{CN})_{2} \mathrm{C},[\mathrm{Ru}](\mathrm{Br}) \mathrm{C}$, and [Ru](NCO)C are available (see Table 15) [115].

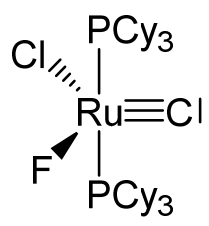

$[\mathrm{Ru}](\mathrm{F}) \mathrm{C}$

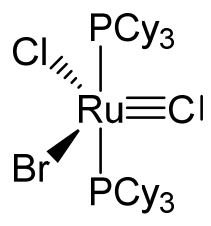

$[\mathrm{Ru}](\mathrm{Br}) \mathrm{C}$

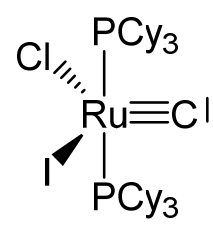

[Ru](I)C<smiles>Cl[R](Cl)(Cl)[Pb]</smiles>

$[\mathrm{Ru}](\mathrm{CN}) \mathrm{C}$

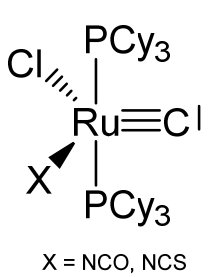

$[\mathrm{Ru}](\mathrm{X}) \mathrm{C}$

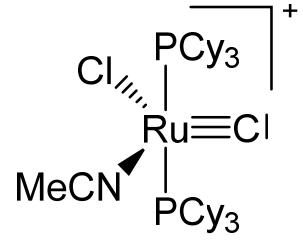

$\{[R u](M e C N) C\} O T f$

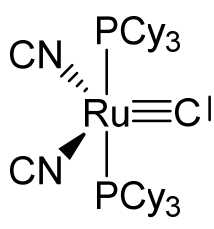

$[\mathrm{Ru}](\mathrm{CN})_{2} \mathrm{C}$

Figure 26. Carbido compounds of $[\mathrm{Ru}] \mathrm{XC}$ with various $\mathrm{X}$. 
Table 15. Carbido complexes with the [Ru]XC core.

\begin{tabular}{cccccc}
\hline & ${ }^{13}$ C NMR & Ru-C & M-C & Ru-C-M & Ref \\
\hline$\{[\mathrm{Ru}](\mathrm{MeCN}) \mathrm{C}\} \mathrm{OTf}$ & 464.75 & $\mathrm{nr}$ & $\mathrm{nr}$ & $\mathrm{nr}$ & {$[115]$} \\
{$[\mathrm{Ru}](\mathrm{CN})_{2} \mathrm{C}$} & 464.70 & $\mathrm{nr}$ & $\mathrm{nr}$ & $\mathrm{nr}$ & {$[115]$} \\
{$[\mathrm{Ru}](\mathrm{F}) \mathrm{C}$} & 474.58 & $\mathrm{nr}$ & $\mathrm{nr}$ & $\mathrm{nr}$ & {$[115]$} \\
{$[\mathrm{Ru}](\mathrm{Br}) \mathrm{C}$} & 471.38 & $\mathrm{nr}$ & $\mathrm{nr}$ & $\mathrm{nr}$ & {$[115]$} \\
{$[\mathrm{Ru}](\mathrm{I}) \mathrm{C}$} & 469.74 & $\mathrm{nr}$ & $\mathrm{nr}$ & $\mathrm{nr}$ & {$[115]$} \\
{$[\mathrm{Ru}](\mathrm{CN}) \mathrm{C}$} & 474.91 & $\mathrm{nr}$ & $\mathrm{nr}$ & $\mathrm{nr}$ & {$[115]$} \\
{$[\mathrm{Ru}](\mathrm{NCO}) \mathrm{C}$} & 473.51 & $\mathrm{nr}$ & $\mathrm{nr}$ & $\mathrm{nr}$ & {$[115]$} \\
{$[\mathrm{Ru}](\mathrm{NCS}) \mathrm{C}$} & 477.50 & $\mathrm{nr}$ & $\mathrm{nr}$ & $\mathrm{nr}$ & {$[115]$} \\
\hline
\end{tabular}

\subsection{The Systems $\mathrm{OsCl}_{2}\left(\mathrm{PCy}_{3}\right)_{2} \mathrm{C}$ and $\mathrm{OsI}_{2}\left(\mathrm{PCy}_{3}\right)_{2} \mathrm{C}([\mathrm{OsX}] \mathrm{C})$}

The carbido complexes [OsX]C in Figure 27 were studied by X-ray analysis. The most important structural parameter is the Os- $\mathrm{C}$ separation, which for $\mathrm{X}=\mathrm{Cl}$ amounts to 1.689(5) $\AA$ [116]. Single-crystal $\mathrm{X}$-ray diffraction reveals that molecular [OsX]C adopts an approximately square-pyramidal core geometry, with the carbido ligand occupying the apical position and a short Os- $\mathrm{C}$ bond. In the ${ }^{13} \mathrm{C}$ NMR spectrum the signal at $471.8 \mathrm{ppm}$ for $\mathrm{X}=\mathrm{Cl}$ was attributed to the ligand carbon atom. It was synthesized via S-atom abstraction from the thiocarbonyl complex $\mathrm{Os}(\mathrm{CS})\left(\mathrm{PCy}_{3}\right)_{2} \mathrm{Cl}_{2}$ by $\mathrm{Ta}\left(\mathrm{OSi}-t-\mathrm{Bu}_{3}\right)_{3}$. The diiodo derivative was synthesized from $[\mathrm{OsCl}] \mathrm{C}$ upon reacting with 10 eq of $\mathrm{Me}_{3} \mathrm{SiI}$ and exhibits a ${ }^{13} \mathrm{C}$ NMR signal at $446.14 \mathrm{ppm}$.

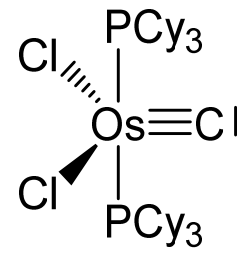

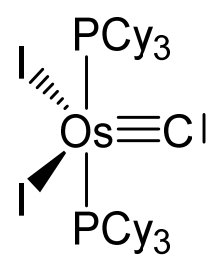

[Os]C

Figure 27. The $[\mathrm{Os}] \mathrm{C}$ core.

\subsection{The System $\left[\mathrm{Tp}^{*} \mathrm{Mo}(\mathrm{CO})_{3} \equiv \mathrm{C}^{-}\left([\mathrm{Mo}]^{-} \mathrm{C}\right)\right.$}

The reaction between $\mathrm{Tp}{ }^{*} \mathrm{Mo}(\mathrm{CO})_{2} \mathrm{CCl}$ (see Figure 28) and $\mathrm{KFeCp}(\mathrm{CO})_{2}$ generates the carbido complex $[\mathrm{Mo}] \mathrm{C} \rightarrow \mathrm{FeCp}(\mathrm{CO})_{2}$ (see Table 16) [117]; see alternative synthesis from $\mathrm{Tp} \mathrm{p}^{*} \mathrm{Mo}(\mathrm{CO})_{2} \mathrm{C}-\mathrm{Li}$ and $\mathrm{ClFeCp}(\mathrm{CO})_{2}$ [118]. When $\mathrm{Tp} * \mathrm{Mo}(\mathrm{CO})_{2} \mathrm{CSe}$ was allowed to react with $\left[\mathrm{Ir}(\mathrm{NCMe})(\mathrm{CO})\left(\mathrm{PPh}_{3}\right)_{2}\right] \mathrm{BF}_{4}$ the tetranuclear carbido complex $\left(\mu-\mathrm{Se}_{2}\right)\left[\mathrm{Ir}_{2}-\{[\mathrm{Mo}] \mathrm{C}\}_{2}(\mathrm{CO})_{2}\left(\mathrm{PPh}_{3}\right)_{2}\right]$ was obtained (see Figure 29) [119]. A solution of $\mathrm{Tp}{ }^{*} \mathrm{Mo}(\mathrm{CO})_{2} \mathrm{CBr}$ in THF was treated with BuLi followed by addition of $\mathrm{HgCl}_{2}$ resulted in the formation of the carbido complex [Mo]C $\rightarrow \mathrm{Hg} \leftarrow \mathrm{C}[\mathrm{Mo}]$ [120]. The platinum complex $[\mathrm{Mo}] \mathrm{C} \rightarrow \mathrm{Pt}\left(\mathrm{PPh}_{3}\right)_{2} \mathrm{Br}$ was prepared from reacting $\left[\left(\mathrm{HB}(\mathrm{pz})_{3}\right] \mathrm{Mo}(\mathrm{CO})_{2} \mathrm{CBr}\right.$ with $\left[\left(\mathrm{PPh}_{3}\right)_{2} \mathrm{Pt}\left(\mathrm{C}_{2} \mathrm{H}_{4}\right)\right][121]$.

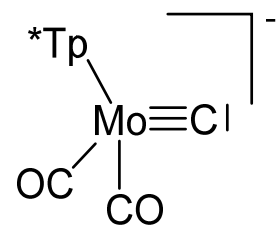

$[\mathrm{Mo}]^{-\mathrm{C}}$

Figure 28. The $[\mathrm{Mo}]^{-} \mathrm{C}$ core. $\mathrm{Tp}^{*}=\operatorname{tris}\left(3,5\right.$-dimethylpyrazolyl)borate, $\left[\mathrm{HB}\left(\mathrm{pzMe}_{2}\right)_{3}\right]^{-}$or $\left[\mathrm{HB}(\mathrm{pz})_{3}\right]^{-}$. 
Table 16. Compounds with $[\mathrm{Mo}]^{-} \mathrm{C}$ core with $\mathrm{Tp}^{*}=\left[\mathrm{HB}\left(\mathrm{pzMe}_{2}\right)_{3}\right]^{-}$or $\left[\mathrm{HB}(\mathrm{pz})_{3}\right]^{-}$.

\begin{tabular}{clcccc}
\hline & Mo-C & M-C & Mo-C-M & ${ }^{1^{3} \text { C NMR }}$ & Ref \\
\hline & \multicolumn{2}{c}{$\mathrm{Tp}^{*}$ is $\left[\mathrm{HB}(\mathrm{pzMe})_{3}\right]^{-}$} & & & \\
{$[\mathrm{Mo}] \mathrm{C} \rightarrow \mathrm{FeCp}(\mathrm{CO})_{2}$} & $1.819(6)$ & $1.911(8)$ & $172.2(5)$ & 381 & {$[117]$} \\
$\left(\mu-\mathrm{Se}_{2}\right)\left[\mathrm{Ir}_{2}-\{[\mathrm{Mo}] \mathrm{C}\}_{2}(\mathrm{CO})_{2}\left(\mathrm{PPh}_{3}\right)_{2}\right]$ & $1.843(5)$ & $1.974(5)$ & $171.3(3) 168.2(3)$ & 286.1 & {$[119]$} \\
{$[\mathrm{Mo}] \mathrm{C} \rightarrow \mathrm{Hg} \leftarrow \mathrm{C}[\mathrm{Mo}]$} & $\mathrm{nr}$ & $\mathrm{nr}$ & $\mathrm{nr}$ & 373 & {$[120]$} \\
{$[\mathrm{Mo}] \mathrm{C} \rightarrow \mathrm{AuPPh}_{3}$} & $\mathrm{nr}$ & $\mathrm{nr}$ & $\mathrm{nr}$ & $\mathrm{nr}$ & {$[122]$} \\
& $\mathrm{Tp}$ & $\mathrm{nr}\left[\mathrm{HB}(\mathrm{pz})_{3}\right]^{-}$ & & & \\
{$[\mathrm{Mo}] \mathrm{C} \rightarrow \mathrm{Pt}\left(\mathrm{PPh}_{3}\right)_{2} \mathrm{Br}$} & $\mathrm{nr}$ & $\mathrm{nr}$ & $\mathrm{nr}$ & 339.0 & {$[121]$} \\
\hline
\end{tabular}

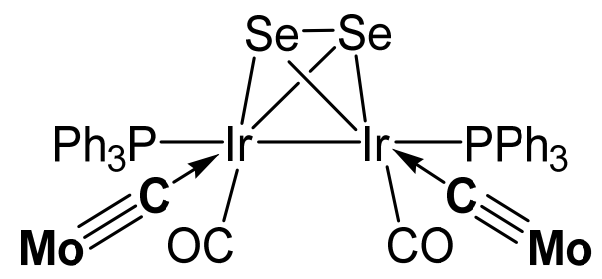

Figure 29. Selected structure of compounds with the $[\mathrm{Mo}]^{-} \mathrm{C}$ moiety.

\subsection{Unique Mo Carbido Complex}

A further unique carbido complex was described recently as shown in Figure 30. A signal at $360.8 \mathrm{ppm}$ in the ${ }^{13} \mathrm{C}$ NMR spectrum was assigned to the ligand carbon atom [123].

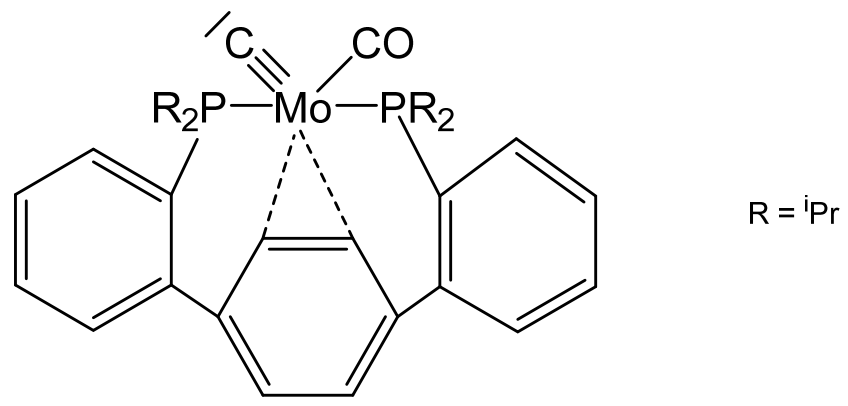

Figure 30. The carbido complex with the $\mathrm{P}_{2}(\mathrm{CO}) \mathrm{Mo} \equiv \mathrm{C}$ core.

\subsection{The System $\left[\mathrm{Tp}^{*} \mathrm{~W}(\mathrm{CO})_{3} \equiv \mathrm{C}\right]^{-}\left([\mathrm{W}]^{-} \mathrm{C}\right)$}

Reaction of $[\mathrm{W}] \mathrm{C}-\mathrm{Li}(\mathrm{THF})$ with $\mathrm{NiCl}_{2}\left(\mathrm{PEt}_{3}\right)_{2}$ produced the complex $[\mathrm{W}] \mathrm{C} \rightarrow \mathrm{NiCl}\left(\mathrm{PEt}_{3}\right)_{2}$ in Figure 31 [124]. Similarly, with [W]C-Li(THF) and $\mathrm{FeCl}(\mathrm{CO})_{2} \mathrm{Cp}$ or $\mathrm{HgCl}_{2}$ the compounds $[\mathrm{W}] \mathrm{C} \rightarrow \mathrm{Fe}(\mathrm{CO})_{2} \mathrm{Cp}$ and $[\mathrm{W}] \mathrm{C} \rightarrow \mathrm{Hg} \leftarrow \mathrm{C}[\mathrm{W}]$, respectively, were obtained. [W]C $\rightarrow \mathrm{AuPEt}_{3}$ was prepared from reacting $[\mathrm{W}] \mathrm{C} \rightarrow \mathrm{SnMe}_{3}$ with $\mathrm{AuCl}\left(\mathrm{SMe}_{2}\right)$ followed by addition of $\mathrm{PEt}_{3}$. A similar reaction with $\mathrm{AuCl}\left(\mathrm{PPh}_{3}\right)$ yielded $[\mathrm{W}] \mathrm{C} \rightarrow \mathrm{AuPPh}_{3} .[\mathrm{W}] \mathrm{C} \rightarrow \mathrm{AuAsPh}_{3}$ and $[\mathrm{W}] \mathrm{C} \rightarrow \mathrm{AuPPh}_{3}$ form a tetrameric assembly as depicted in Figure 32. The X-ray analysis of the tetrameric unit revealed Au-C distances of 1.995 and 2.078 $\AA$ and the W-C distance is $1.877 \AA$ [122].

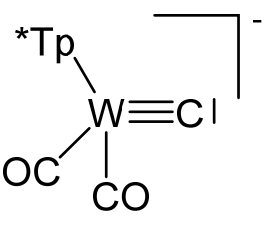

$[\mathrm{W}]^{-\mathrm{C}}$

Figure 31. The $[\mathrm{W}]^{-} \mathrm{C}$ core. $\mathrm{T}^{*}=\operatorname{tris}\left(3,5\right.$-dimethylpyrazolyl)borate, $\left[\mathrm{HB}\left(\mathrm{pzMe}_{2}\right)_{3}\right]^{-}$. 


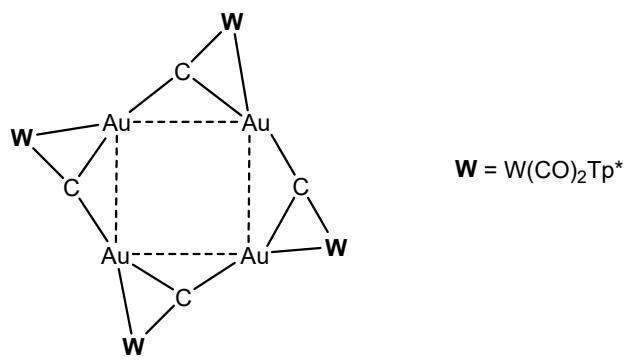

Figure 32. Tetrameric unit from $[\mathrm{W}] \mathrm{C} \rightarrow \mathrm{AuAsPh}_{3}$ and $[\mathrm{W}] \mathrm{C} \rightarrow \mathrm{AuPPh}_{3}[122]$.

The terpyridine complex salt $\{[\mathrm{W}] \mathrm{C} \rightarrow \mathrm{Pt}($ terpy $)\} \mathrm{PF}_{6}$ was obtained from $[\mathrm{W}] \mathrm{C}-\mathrm{Li}$ and $\left[\mathrm{PtCl}(\right.$ terpy) $] \mathrm{PF}_{6}$; the neutral complex $[\mathrm{W}] \mathrm{C} \rightarrow \mathrm{PtCl}($ terpyC$[\mathrm{W}]$ ) (see Figure 33 ) was prepared from the same starting material and $\left[\mathrm{PtCl}_{2}\right.$ (phen)] (see Table 17) [125].
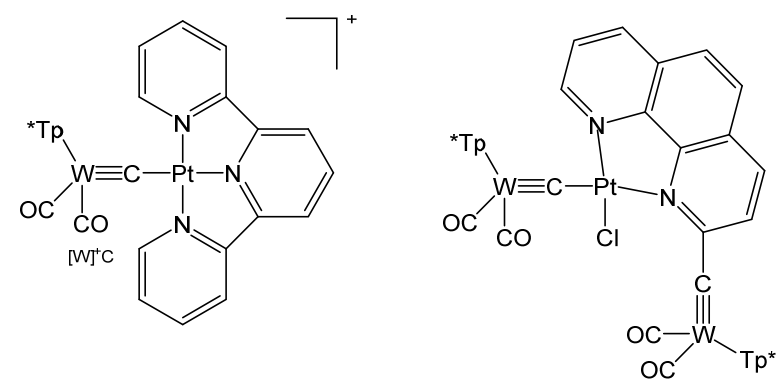

Figure 33. Structural representation of [W]C $\rightarrow \mathrm{Pt}$ complexes [125].

Table 17. Compounds with $[\mathrm{W}]^{-} \mathrm{C}$ core. $\mathrm{Tp}^{*}=\left[\mathrm{HB}\left(\mathrm{pzMe}_{2}\right)_{3}\right]^{-}$.

\begin{tabular}{cccccc}
\hline & W-C & M-C & W-C-M & ${ }^{13}$ C NMR & Ref \\
\hline$[\mathrm{W}] \mathrm{C} \rightarrow \mathrm{NiCl}\left(\mathrm{PEt}_{3}\right)_{2}$ & $\mathrm{nr}$ & $\mathrm{nr}$ & $\mathrm{nr}$ & $\mathrm{nr}$ & {$[124]$} \\
{$[\mathrm{W}] \mathrm{C} \rightarrow \mathrm{Fe}(\mathrm{CO})_{2} \mathrm{Cp}$} & $\mathrm{nr}$ & $\mathrm{nr}$ & $\mathrm{nr}$ & $\mathrm{nr}$ & {$[122]$} \\
{$[\mathrm{W}] \mathrm{C} \rightarrow \mathrm{Hg} \leftarrow \mathrm{C}[\mathrm{W}]$} & $\mathrm{nr}$ & $\mathrm{nr}$ & $\mathrm{nr}$ & $\mathrm{nr}$ & {$[122]$} \\
{$[\mathrm{W}] \mathrm{C} \rightarrow \mathrm{AuAsPh}_{3}$} & $\mathrm{nr}$ & $\mathrm{nr}$ & $\mathrm{nr}$ & $\mathrm{nr}$ & {$[122]$} \\
{$[\mathrm{W}] \mathrm{C} \rightarrow \mathrm{AuPPh}_{3}$} & $\mathrm{nr}$ & $\mathrm{nr}$ & $\mathrm{nr}$ & $\mathrm{nr}$ & {$[122]$} \\
{$[\mathrm{W}] \mathrm{C} \rightarrow \mathrm{AuPEt}_{3}$} & $\mathrm{nr}$ & $\mathrm{nr}$ & $\mathrm{nr}$ & 397.7 & {$[122]$} \\
$\left\{[\mathrm{W}] \mathrm{C} \rightarrow \mathrm{Pt}_{\text {terpy) }}\right\} \mathrm{PF}_{6}$ & $1.835(5)$ & $1.938(5)$ & $176.3(3)$ & 368 & {$[125]$} \\
$\left.[\mathrm{W}] \mathrm{C} \rightarrow \mathrm{PtCl}_{\text {terpyC}}[\mathrm{W}]\right)$ & $1.853(14)$ & $1.890(14)$ & $173.4(9)$ & 331.3 & {$[125]$} \\
\hline
\end{tabular}

\subsection{The Systems $\mathrm{N}_{3} \mathrm{MoC}$ and $\mathrm{O}_{3} \mathrm{MoC}$}

The potassium salt of ${ }^{\mathrm{N}} \mathrm{MOC}^{-}$in Figure 34 is dimeric with two $\mathrm{K}^{+}$ions bridging two anions and can be transformed with the crown ethers 2.0-benzo-15-crown-5 and 1.0 2,2,2-crypt into the related ion pairs. X-ray analysis of the crown ether salt revealed a Mo-C distance of 1.713(9) $\AA$ [26,126].

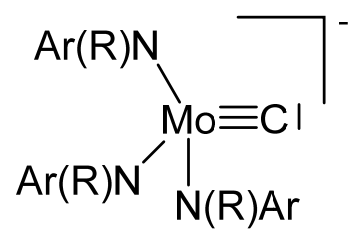

$\left[{ }^{\mathrm{N}} \mathrm{Mo}\right]^{-} \mathrm{C}$

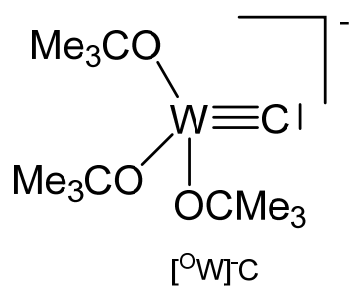

$\mathrm{Ar}=\mathrm{C}_{6} \mathrm{H}_{3}-\mathrm{Me}_{2}-3,5$

$\mathrm{R}=\mathrm{C}\left(\mathrm{CD}_{3}\right)_{2} \mathrm{CH}_{3}$

Figure 34. The $\left[{ }^{\mathrm{N}} \mathrm{Mo}\right]^{-} \mathrm{C}$ and $\left[{ }^{\mathrm{O}} \mathrm{W}\right]^{-} \mathrm{C}$ core. 
The complex $\left[{ }^{\mathrm{O}} \mathrm{W}\right] \mathrm{C} \rightarrow \mathrm{Ru}(\mathrm{CO})_{2} \mathrm{Cp}$ was prepared from reacting $\left[{ }^{\mathrm{O}} \mathrm{W}\right] \mathrm{C}-\mathrm{Et}$ with $\mathrm{Ru}(\mathrm{C} \equiv \mathrm{CMe})(\mathrm{CO}){ }_{2} \mathrm{Cp}$ under loss of MeCCEt. The ligand $\mathrm{C}$ atom resonates at $237.3 \mathrm{ppm}\left({ }^{1} J_{\mathrm{WC}}=290.1 \mathrm{~Hz}\right)$. Distances are $\mathrm{W}-\mathrm{C}=1.75(2) \AA, \mathrm{Ru}-\mathrm{C}=2.09(2) \AA$ and the W-C-Ru angle amounts to $177(2)^{\circ}$ [127].

\subsection{Symmetrically Bridged Carbido Complexes $M=C=M$}

\subsubsection{The $\mathrm{Fe}=\mathrm{C}=\mathrm{Fe}$ Core}

$[\mathrm{Fe}(\mathrm{TPP})]_{2} \mathrm{C}$ was obtained from $\mathrm{Fe}^{\mathrm{III}}(\mathrm{TPP}) \mathrm{Cl}$ in the presence of iron powder by reacting with $\mathrm{CI}_{4}$ (TPP $=5,10,15,20$-tetraphenylporphyrin; according to $\mathrm{Fe}^{\mathrm{II}}$ the complex is diamagnetic [128]. The complex was also obtained upon reacting $\mathrm{Fe}(\mathrm{TPP})$ with $\mathrm{Me}_{3} \mathrm{SiCCl}_{3}$ [129]; see also [130]. An X-ray analysis was performed in [131] and later in [130]. The Mössbauer spectrum is published in [132]. $[\mathrm{Fe}(\mathrm{TTP})]_{2} \mathrm{C}$ (TTP = tetratolylporphyrine) was similarly obtained from $\mathrm{Fe}(\mathrm{TTP})$ with $\mathrm{Me}_{3} \mathrm{SiCCl}_{3}$ [129]. $[\mathrm{Fe}(\text { oep})]_{2} \mathrm{C}$ (oep = octaethylporphyrine) was prepared from $[\mathrm{ClFe}($ oep$)]$ and $\mathrm{HCCl}_{3}$ and studied by X-ray analysis ans Mössbauer spectroscopy (see Table 18) [132].

Table 18. Fe-C distances (in $\AA$ ) and Fe-C-Fe angles (in deg). ${ }^{13} \mathrm{C}$ NMR of the bridging carbon atom in ppm.

\begin{tabular}{cccccc}
\hline & ${ }^{13} \mathbf{C ~ N M R}$ & Fe-C & Fe-C & Fe-C-Fe & Ref \\
\hline$[\mathrm{Fe}(\mathrm{TPP})]_{2} \mathrm{C}$ & $\mathrm{nr}$ & $1.683(1)$ & 1.675 & 180 & {$[130,131]$} \\
{$[\mathrm{Fe}(\mathrm{TTP})]_{2} \mathrm{C}$} & $\mathrm{nr}$ & $\mathrm{nr}$ & $\mathrm{nr}$ & $\mathrm{nr}$ & {$[129]$} \\
{$[\mathrm{Fe}(\mathrm{oep})]_{2} \mathrm{C}$} & $\mathrm{nr}$ & $1.6638(9)$ & $1.6638(9)$ & $179.5(3)$ & {$[132]$} \\
$(\mathrm{TPP}) \mathrm{Fe}=\mathrm{C}=\mathrm{Fe}(\mathrm{CO})_{4}$ & $\mathrm{nr}$ & $\mathrm{nr}$ & $\mathrm{nr}$ & $\mathrm{nr}$ & {$[121]$} \\
$(\mathrm{TCNP}) \mathrm{Fe}=\mathrm{C}=\mathrm{Fe}(\mathrm{CO})_{4}$ & $\mathrm{nr}$ & $\mathrm{nr}$ & $\mathrm{nr}$ & $\mathrm{nr}$ & {$[121]$} \\
{$[\mathrm{Fe}(\mathrm{pc})]_{2} \mathrm{C}$} & $\mathrm{nr}$ & $\mathrm{nr}$ & $\mathrm{nr}$ & $\mathrm{nr}$ & {$[95]$} \\
$\left\{[\mathrm{Fe}(\mathrm{pc})]_{2} \mathrm{C}\right\}\left(\mathrm{I}_{3}\right)_{0.66}$ & $\mathrm{nr}$ & $\mathrm{nr}$ & $\mathrm{nr}$ & $\mathrm{nr}$ & {$[95]$} \\
{$[(\mathrm{py}) \mathrm{Fe}(\mathrm{pc})]_{2} \mathrm{C}$} & $\mathrm{nr}$ & $1.69(2)$ & $1.69(2)$ & $177.5(8)$ & {$[133]$} \\
{$[(1-\mathrm{meim}) \mathrm{Fe}(\mathrm{pc})]_{2} \mathrm{C}$} & $\mathrm{nr}$ & $1.70(1)$ & $1.70(1)$ & $178(1)$ & {$[134]$} \\
{$[(4-\mathrm{Mepy}) \mathrm{Fe}(\mathrm{pc})]_{2} \mathrm{C}$} & $\mathrm{nr}$ & $\mathrm{nr}$ & $\mathrm{nr}$ & $\mathrm{nr}$ & {$[133]$} \\
{$[(\mathrm{pip}) \mathrm{Fe}(\mathrm{pc})]_{2} \mathrm{C}$} & $\mathrm{nr}$ & $\mathrm{nr}$ & $\mathrm{nr}$ & $\mathrm{nr}$ & {$[133]$} \\
$[\mathrm{thf}) \mathrm{Fe}(\mathrm{pc})]_{2} \mathrm{C}$ & $\mathrm{nr}$ & $1.71(2)$ & $1.64(2)$ & $180(1)$ & {$[130]$} \\
{$[(\mathrm{thf})(\mathrm{TPP}) \mathrm{Fe}=\mathrm{C}=\mathrm{Fe}(\mathrm{pc})(\mathrm{thf})]$} & $\mathrm{nr}$ & $1.71(1)$ & $1.65(1)$ & $179(1)$ & {$[130]$} \\
$\left(\mathrm{Bu} \mathrm{H}_{4} \mathrm{~N}\right)_{2}\left\{[(\mathrm{~F}) \mathrm{Fe}(\mathrm{pc})]_{2} \mathrm{C}\right\}$ & $\mathrm{nr}$ & $1.687(4)$ & $1.687(4)$ & $179.5(3)$ & {$[135]$} \\
$\left(\mathrm{Bu}{ }_{4} \mathrm{~N}\right)_{2}\left\{[(\mathrm{Cl}) \mathrm{Fe}(\mathrm{pc})]_{2} \mathrm{C}\right\}$ & $\mathrm{nr}$ & $\mathrm{nr}$ & $\mathrm{nr}$ & $\mathrm{nr}$ & {$[135]$} \\
$\left(\mathrm{Bu} \mathrm{u}_{4} \mathrm{~N}\right)_{2}\left\{[(\mathrm{Br}) \mathrm{Fe}(\mathrm{pc})]_{2} \mathrm{C}\right\}$ & $\mathrm{nr}$ & $\mathrm{nr}$ & $\mathrm{nr}$ & $\mathrm{nr}$ & {$[135]$} \\
\hline
\end{tabular}

The mixed carbido compounds $(\mathrm{TPP}) \mathrm{Fe}=\mathrm{C}=\mathrm{Fe}(\mathrm{CO})_{4}$, and $(\mathrm{TCNP}) \mathrm{Fe}=\mathrm{C}=\mathrm{Fe}(\mathrm{CO})_{4}(\mathrm{TCNP}=$ Tetrakisp-cyanophenylporphyrinate) were synthesized from $\left[(\mathrm{TPP}) \mathrm{FeCCl}_{2}\right]$ or $(\mathrm{TCNP}) \mathrm{FeCCl}_{2}$ and $\left[\mathrm{Na}_{2} \mathrm{Fe}(\mathrm{CO})_{4}\right]$; characterization proceeded via IR spectroscopy [121].

$[\mathrm{Fe}(\mathrm{pc})]_{2} \mathrm{C}$ was prepared from $[\mathrm{ClFe}(\mathrm{pc})]^{-}$and $\mathrm{KOH} / \mathrm{HCCl}_{3}$ [132], or from $\mathrm{Fe}(\mathrm{pc})$ and $\mathrm{CI}_{4}$ in the presence of sodium dithionite [95,136], see also [134]. It also forms upon hydrolysis of $\left(\mathrm{Bu}_{4} \mathrm{~N}\right)_{2}$ $\left\{[(\mathrm{F}) \mathrm{Fe}(\mathrm{pc})]_{2} \mathrm{C}\right\}$ in acetone [135]. Oxidation with $\mathrm{I}_{2}$ generates $\left\{[\mathrm{Fe}(\mathrm{pc})]_{2} \mathrm{C}\right\}\left(\mathrm{I}_{3}\right)_{0.66}$ which was characterized by IR, Mössbauer spectroscopy and powder X-ray diffraction [95].

A series of six-coordinate $\mathrm{N}$-Base adducts of $\mu$-carbido phthalocyanine complexes were reported. The pyridine adduct $[(\mathrm{py}) \mathrm{Fe}(\mathrm{pc})]_{2} \mathrm{C}$ was obtained y dissolution of $[\mathrm{Fe}(\mathrm{pc})]_{2} \mathrm{C}$ in warm pyridine [133] and characterized by Mössbauer spectroscopy [136] and X-ray analysis [133]. [Fe(pc)(1-meim) $\}_{2} \mathrm{C}$ was similarly obtained as the TPP derivate; starting with $\mathrm{pcFe}$ and $\mathrm{CI}_{4}$ followed by addition of sodium dithionite gave the $\mu$-carbido bridged dimer; an $\mathrm{X}$-ray diffraction analysis was reportedd $\left(1\right.$-meim $=1$-methylimidazole, $\mathrm{pc}=$ phthalocyanine) $[134] .[(4-\mathrm{Mepy}) \mathrm{Fe}(\mathrm{pc})]_{2} \mathrm{C}$ and $[(\mathrm{pip}) \mathrm{Fe}(\mathrm{pc})]_{2} \mathrm{C}$ were similarly obtained and studied by IR and Mössbauer spectroscopy [136].

$[(\text { thf }) \mathrm{Fe}(\mathrm{pc})]_{2} \mathrm{C}$ forms on dissolving $[\mathrm{Fe}(\mathrm{pc})]$ in THF. The asymmetric $\mu$-carbido complex $[($ thf $)(\mathrm{TPP}) \mathrm{Fe}=\mathrm{C}=\mathrm{Fe}(\mathrm{pc})($ thf $)]$ stems from the reaction of $\left[\mathrm{FeCCl}_{2}(\mathrm{TPP})\right]$ with $[\mathrm{Fe}(\mathrm{pc})]$-; both compounds were characterized by $\mathrm{X}$-ray analyses [130]. 
Anionic six-coordinate $\mu$-carbido complexes $\left(\mathrm{Bu}_{4} \mathrm{~N}\right)_{2}\left\{[(\text { hal }) \mathrm{Fe}(\mathrm{pc})]_{2} \mathrm{C}\right\}$ were reported $($ hal $=\mathrm{F}$. $\mathrm{Cl}$. $\mathrm{Br})$ and obtained from reacting $[\mathrm{Fe}(\mathrm{pc})]_{2} \mathrm{C}$ with $\left(\mathrm{Bu}_{4} \mathrm{~N}\right)(\mathrm{hal})\left(\mathrm{F}: \mathrm{RT}, \mathrm{Cl}: 115^{\circ}, \mathrm{Br}: 140^{\circ}\right)$ in solution $(\mathrm{F})$ and in a melt [135].

\subsection{2. $\mathrm{The} \mathrm{Rh}=\mathrm{C}=\mathrm{Rh}$ Core}

$\left[\mathrm{Rh}\left(\mathrm{PEt}_{3}\right)_{2}\left(\mathrm{SGePh}_{3}\right)\right]_{2} \mathrm{C}$ was obtained upon reacting $\mathrm{Rh}\left(\mathrm{PEt}_{3}\right)_{2}\left(\mathrm{SGePh}_{3}\right) \mathrm{CS}$ with $\mathrm{Rh}\left(\mathrm{PEt}_{3}\right)_{3}(\mathrm{Bpin})$ via the intermediate mixed carbido complex $\left(\mathrm{SGePh}_{3}\right)\left(\mathrm{PEt}_{3}\right)_{2} \mathrm{Rh}=\mathrm{C}=\mathrm{Rh}\left(\mathrm{PEt}_{3}\right)_{2}(\mathrm{SBpin})$ which rearranges to this complex and $\left[\mathrm{Rh}\left(\mathrm{PEt}_{3}\right)_{2}(\mathrm{SBpin})\right]_{2}$. The X-ray analysis was performed (see Table 19) [137] $\left[\mathrm{Rh}\left(\mathrm{PEt}_{3}\right)_{2}(\mathrm{SBpin})\right]_{2} \mathrm{C}$ was prepared earlier by the same working group from $\mathrm{Rh}\left(\mathrm{PEt}_{3}\right)_{3}(\mathrm{Bpin})$ and $0,5 \mathrm{eq}$ of $\mathrm{CS}_{2}$ (X-ray data (see Table 19). Addition of $\mathrm{MeOH}$ generated the carbido complex $\left[\mathrm{Rh}\left(\mathrm{PEt}_{3}\right)_{2}(\mathrm{SH})\right]_{2} \mathrm{C}$ [138]. $\quad\left[\mathrm{Rh}(\mathrm{Cl})\left(\mathrm{PPh}_{3}\right)_{2}\right]_{2} \mathrm{C}$ resulted from reacting the thiocarbonyl complex $\mathrm{Rh}(\mathrm{Cl})\left(\mathrm{PPh}_{3}\right)_{2} \mathrm{CS}$ with HBCat. The central $\mathrm{C}$ atom resonates at $424 \mathrm{ppm}\left(\mathrm{t},{ }^{1} \mathrm{~J}_{\mathrm{RhC}}=47 \mathrm{~Hz}\right)$. In the chloro complex the chloride ion can be replaced with $\mathrm{K}\left[\left(\mathrm{H}_{2} \mathrm{~B}(\mathrm{pz})_{2}\right], \mathrm{K}\left[\left(\mathrm{H}_{2} \mathrm{~B}(\mathrm{pzMe})_{2}\right]\right.\right.$, or $\mathrm{K}\left[\left(\mathrm{HB}(\mathrm{pz})_{3}\right]\right.$ to produce the carbido complexes $\left[\mathrm{Rh}\left(\mathrm{H}_{2} \mathrm{~B}(\mathrm{pz})_{2}\right)\left(\mathrm{PPh}_{3}\right)\right]_{2} \mathrm{C}$, $\left[\mathrm{Rh}\left(\mathrm{H}_{2} \mathrm{~B}(\mathrm{pzMe})_{2}\right)\left(\mathrm{PPh}_{3}\right)\right]_{2} \mathrm{C}$, and $\left[\mathrm{Rh}\left(\mathrm{HB}(\mathrm{pz})_{3}\right)\left(\mathrm{PPh}_{3}\right)\right]_{2} \mathrm{C}$, respectively (see Figure 35$)$. The unusual asymmetric carbido complex $\left[\mathrm{Rh}_{2} \mathrm{H}(\mu-\mathrm{C})\left(\mu-\mathrm{C}_{6} \mathrm{H}_{4} \mathrm{PPh}_{2}-2\right)\left\{\mathrm{HB}\left(\mathrm{pzMe}_{2}\right)_{3}\right\}_{2}\right]$ contains a $\mathrm{Rh}^{\mathrm{I}}$ atom with a shorter $\mathrm{Rh}-\mathrm{C}$ distance, while the $\mathrm{Rh}^{\mathrm{III}}-\mathrm{C}$ distance is longer [139].

Table 19. Rh-C distances (in $\AA$ ) and Rh-C-Rh angles (in deg). ${ }^{13} \mathrm{C}$ NMR of the bridging carbon atom in ppm.

\begin{tabular}{|c|c|c|c|c|c|}
\hline & ${ }^{13} \mathrm{C}$ NMR & Rh-C & Rh-C & Rh-C-Rh & Ref \\
\hline$\left[\mathrm{Rh}\left(\mathrm{PEt}_{3}\right)_{2}(\mathrm{SBpin})\right]_{2} \mathrm{C}$ & $\mathrm{nr}$ & $1.790(7)$ & $1.766(7)$ & $176.1(4)$ & {$[137,138]$} \\
\hline$\left[\mathrm{Rh}(\mathrm{Cl})\left(\mathrm{PPh}_{3}\right)_{2}\right]_{2} \mathrm{C}$ & $424.4{ }^{1} \mathrm{~J}_{\mathrm{RhC}}=47$ & $1.7828(19)$ & $1.7828(19)$ & $\mathrm{nr}$ & [139] \\
\hline$\left[\mathrm{Rh}\left(\mathrm{H}_{2} \mathrm{~B}(\mathrm{pz})_{2}\right)\left(\mathrm{PPh}_{3}\right)\right]_{2} \mathrm{C}$ & $\mathrm{nr}$ & $1.7644(11)$ & $1.7644(11)$ & $169.1(7)$ & [139] \\
\hline$\left[\mathrm{Rh}_{2} \mathrm{H}(\mu-\mathrm{C})\left(\mu-\mathrm{C}_{6} \mathrm{H}_{4} \mathrm{PPh}_{2}-2\right)\left\{\mathrm{HB}\left(\mathrm{pzMe}_{2}\right)_{3}\right\}_{2}\right]$ & $447.2^{1} \mathrm{~J}_{\mathrm{RhC}}=40,50$ & $1.740(6)$ & $1.818(6)$ & $165.9(3)$ & {$[139]$} \\
\hline
\end{tabular}

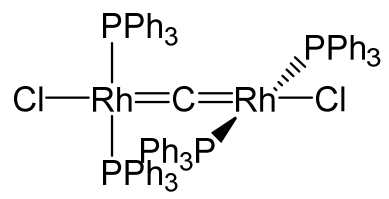

$\left[\mathrm{Rh}(\mathrm{Cl})\left(\mathrm{PPh}_{3}\right)_{2}\right]_{2} \mathrm{C}$<smiles>N[R](N)(N)[R](N)([PH3+])=C(P)[Pb](N)(N)N</smiles>

$\left[\mathrm{Rh}\left(\mathrm{HB}(\mathrm{pz})_{3}\right)\left(\mathrm{PPh}_{3}\right)\right]_{2} \mathrm{C}$

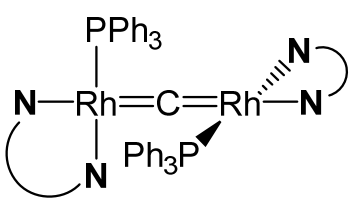

$\left[\mathrm{Rh}\left(\mathrm{H}_{2} \mathrm{~B}(\mathrm{pz})_{2}\right)\left(\mathrm{PPh}_{3}\right)\right]_{2} \mathrm{C}$ $\left[\mathrm{Rh}\left(\mathrm{H}_{2} \mathrm{~B}\left(\mathrm{pzMe}_{2}\right)_{2}\right)\left(\mathrm{PPh}_{3}\right)\right]_{2} \mathrm{C}$

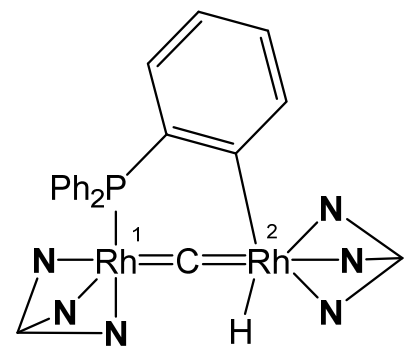

$\left[R h_{2} \mathrm{H}(\mu-\mathrm{C})\left(\mu-\mathrm{C}_{6} \mathrm{H}_{4} \mathrm{PPh}_{2}-2\right)\left\{\mathrm{HB}\left(\mathrm{pz} \mathrm{Me}_{2}\right)_{3}\right\}_{2}\right]$<smiles></smiles>

Figure 35. Selected structures of $\mathrm{Rh}=\mathrm{C}=\mathrm{Rh}$ complexes. 


\subsection{3. $\mathrm{The} \mathrm{Ru}=\mathrm{C}=\mathrm{Ru}$ Core}

The tetranuclear carbido complex $\left[\mathrm{Ru}\left(\mathrm{PEt}_{3}\right) \mathrm{Cl}\left(\mu-\mathrm{Cl}_{3}\right) \mathrm{RuAr}\right]_{2} \mathrm{C}$ was prepared from the reaction of [(p-cymene $\left.) \mathrm{Ru}(\mu-\mathrm{Cl})_{3} \mathrm{RuCl}\left(\mathrm{C}_{2} \mathrm{H}_{4}\right)-\left(\mathrm{PCy}_{3}\right)\right]$ with $\mathrm{HCCH}$ in THF. X-ray analysis adopts $\mathrm{Ru}-\mathrm{C}$ distances of 1.877(9) $\AA$ and a Ru-C-Ru angle of 178.8(9) (see Figure 36) [140].

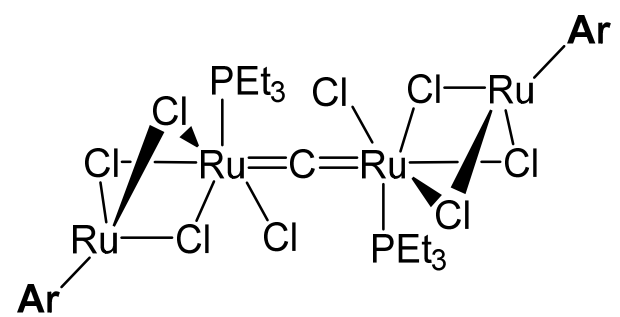

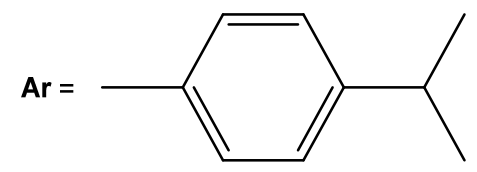

\section{$\left[\mathrm{Ru}\left(\mathrm{PEt}_{3}\right) \mathrm{Cl}\left(\mu-\mathrm{Cl}_{3}\right) \mathrm{RuAr}\right]_{2} \mathrm{C}$}

Figure 36. Structural representation of the Ru carbido complex $\left[\mathrm{Ru}\left(\mathrm{PEt}_{3}\right) \mathrm{Cl}\left(\mu-\mathrm{Cl}_{3}\right) \mathrm{RuAr}\right]_{2} \mathrm{C}$.

Five coordinate $[\mathrm{Ru}(\mathrm{pc})]_{2} \mathrm{C}$ with $\mathrm{pc}=$ phthalocyaninate was obtained from $\mathrm{H}\left[\mathrm{RuCl}_{2}(\mathrm{pc})\right]$ and $\mathrm{CCl}_{2}$ (in situ from $\mathrm{KOH} / \mathrm{HCCl}_{3}$ ) [132]. The related pyridine adduct with six-coordinate $\mathrm{Ru}(\mathrm{IV})[(\mathrm{py}) \mathrm{Ru}(\mathrm{pc})]_{2} \mathrm{C}$ was obtained upon dissolution of $[\mathrm{Ru}(\mathrm{pc})]_{2} \mathrm{C}$ in warm pyridine. X-ray analysis revealed a Ru-C distance of 1.77(1) Å and a Ru-C-Ru angle of $174.5(8)^{\circ}$ [136].

\subsubsection{The $\operatorname{Re}=\mathrm{C}=\operatorname{Re}$ Core}

The unique carbido complex $\left[\operatorname{Re}(\mathrm{CO})_{2} \mathrm{Cp}\right]_{2} \mathrm{C}$ in Figure 37 results from reaction of $\left[\operatorname{Re}(\right.$ thf $)(\mathrm{CO})_{2}$ $\left.\left(\eta-\mathrm{C}_{5} \mathrm{H}_{5}\right)\right], \mathrm{CS}_{2}$, and $\mathrm{PPh}_{3}$ (with the aim of the thiocarbonyl complex $\left[\operatorname{Re}(\mathrm{CS})(\mathrm{CO})\left(\eta-\mathrm{C}_{5} \mathrm{H}_{5}\right)\right]$ ) as by-product in small amounts. X-ray analysis revealed Re-C distances of 1.882(14) and 1.881(14) $\AA$ and a Re-C-Re angle of $173.3(7)^{\circ}$. A ${ }^{13} \mathrm{C}$ NMR shift for the bridging carbon atom at $\delta=436.4 \mathrm{ppm}$ was measured [141].

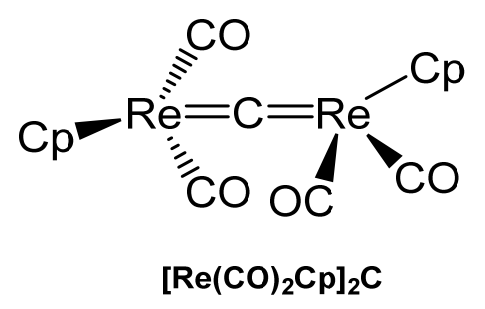

Figure 37. Structural representation of the Re carbido complex $\left[\operatorname{Re}(\mathrm{CO})_{2} \mathrm{Cp}\right]_{2} \mathrm{C}$.

\subsubsection{The $\mathrm{W}=\mathrm{C}=\mathrm{W}$ Core}

The oxo complex $\left({ }^{t} \mathrm{Bu}_{3} \mathrm{SiO}\right)_{2}(\mathrm{O}) \mathrm{W}=\mathrm{C}=\mathrm{WCl}_{2}\left(\mathrm{OSi}^{t} \mathrm{Bu}_{3}\right)_{2}$ in Figure 38 formed in high yield from thermolysis of [(siloxo $\left.{ }_{2} \mathrm{Cl}(\mathrm{CO}) \mathrm{W}\right]_{2}$ in toluene with loss of $\mathrm{CO}$; in the ${ }^{13} \mathrm{C}$ NMR spectrum the carbide $\mathrm{C}$ atom resonates at $\delta=379.14 \mathrm{ppm}\left(\mathrm{JWC}_{W \mathrm{C}}=200,180 \mathrm{~Hz}\right)$. Degradation of the (silox $)_{4} \mathrm{C}_{2} \mathrm{~W}_{2}(\mathrm{CNAr})$ complex afforded the imido $\mu$-carbido compound $\left({ }^{t} \mathrm{Bu}_{3} \mathrm{SiO}\right)_{2}(\mathrm{NR}) \mathrm{W}=\mathrm{C}=\mathrm{WCl}_{2}\left(\mathrm{OSi}^{t} \mathrm{Bu}_{3}\right)_{2}$; the ${ }^{13} \mathrm{C} \mathrm{NMR}$ shift of the $\mu-C$ atom appears at $\delta=406.25 \mathrm{ppm}$. X-ray analysis revealed a tetrahedral tungsten core with a W-C distance of 1.994(17) $\AA\left(\mathrm{W}_{1}\right)$ and a distorted square-pyramidal tungsten core with a shorter distance of 1.796(17) $\AA\left(\mathrm{W}_{2}\right)$. The W-C-W bond angle amounts to $176.0(12)^{\circ}$ [142]. 


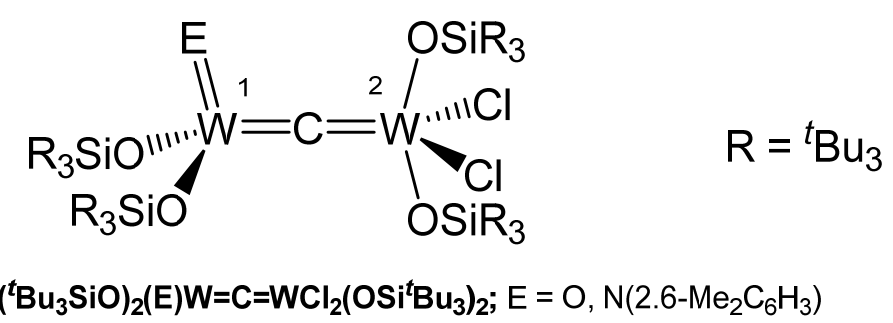

Figure 38. Structural representation of the $\mathrm{W}$ carbido complexes $\left({ }^{t} \mathrm{Bu}_{3} \mathrm{SiO}\right)_{2}(\mathrm{NR}) \mathrm{W}=\mathrm{C}=\mathrm{WCl}{ }_{2}\left(\mathrm{OSi}^{t} \mathrm{Bu}_{3}\right)_{2}$ and $\left({ }^{t} \mathrm{Bu}_{3} \mathrm{SiO}\right)_{2}(\mathrm{O}) \mathrm{W}=\mathrm{C}=\mathrm{WCl}_{2}\left(\mathrm{OSi}^{t} \mathrm{Bu}_{3}\right)_{2}$.

\subsection{Asymmetrically Bridged Carbido Complex $\mathrm{Fe}=\mathrm{C}=\mathrm{M}$}

\subsubsection{The $\mathrm{Fe}=\mathrm{C}=\mathrm{Re}$ Core}

The asymmetrical carbido complex $(\mathrm{TPP}) \mathrm{Fe}=\mathrm{C}=\operatorname{Re}(\mathrm{CO})_{4} \operatorname{Re}(\mathrm{CO})_{5}$ in Figure 39 was prepared upon reacting the dichlorocarbene complex (TPP)Fe $=\mathrm{CCl}_{2}$ with 2 eq of pentacarbonylrhenate, $\left[\operatorname{Re}(\mathrm{CO})_{5}\right]^{-}$, under release of $\mathrm{CO}$ and $2 \mathrm{Cl}^{-}$; TPP is tetraphenylporphyrin. Crystals were analyzed by X-ray diffraction and revealed a $\mathrm{Fe}=\mathrm{C}$ distance of 1.605(13) $\AA$ and a $\mathrm{C}=\mathrm{Re}$ distance of 1.957(12) $\AA$. The Fe-C-Re angle amounts to $173.3(9)^{\circ}$; the Fe-C distance is somewhat smaller than in [(TPP)Fe ${ }_{2} \mathrm{C}$ and the Re-C distance is appreciable longer than in $\left[\operatorname{Re}(\mathrm{CO})_{2} \mathrm{Cp}{ }_{2} \mathrm{C}\right.$. In the ${ }^{13} \mathrm{C}$ NMR spectrum the central carbido $\mathrm{C}$ atom resonates at $211.7 \mathrm{ppm}$ [143].

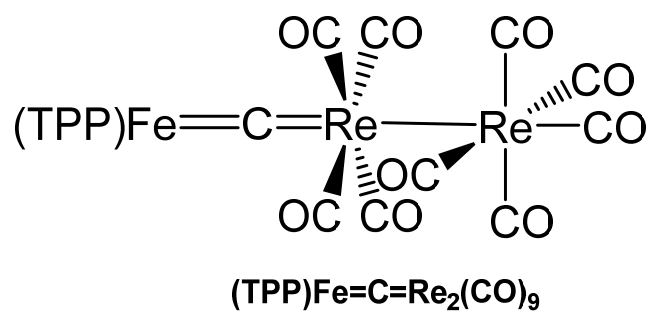

Figure 39. Structural representation of the $\mathrm{Fe}=\mathrm{C}=\mathrm{Re}$ carbido complex $(\mathrm{TPP}) \mathrm{Fe}=\mathrm{C}=\mathrm{Re}_{2}(\mathrm{CO})_{9}$.

\subsubsection{The $\mathrm{Fe}=\mathrm{C}=\mathrm{Mn}$ Core}

The carbido bridged di-manganese complex $(\mathrm{TCNP}) \mathrm{Fe}=\mathrm{C}=\mathrm{Mn}_{2}(\mathrm{CO})_{9}(\mathrm{TCNP}=$ tetrakis (p-cyanophenyl)porphyrinate) (see Figure 40) was synthesized from [(TCNP)Fe $\left.=\mathrm{CCl}_{2}\right]$ and two eq. of $\mathrm{Na}\left(\mathrm{Mn}(\mathrm{CO})_{5}\right.$ in THF and characterized with elemental analysis, IR, and UV spectroscopy [121].

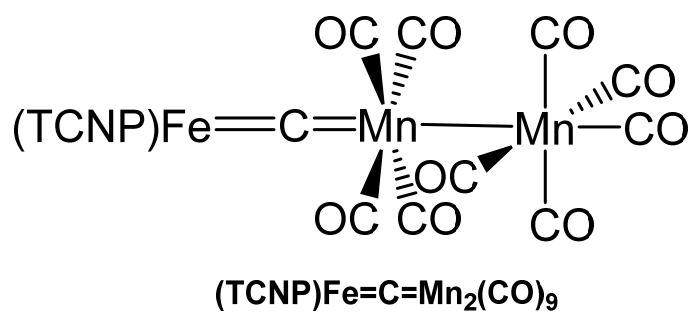

Figure 40. Structural representation of the $\mathrm{Fe}=\mathrm{C}=\mathrm{Mn}$ carbido complex $(\mathrm{TCNP}) \mathrm{Fe}=\mathrm{C}=\mathrm{Mn}_{2}(\mathrm{CO})_{9}$.

\subsubsection{The $\mathrm{Fe}=\mathrm{C}=\mathrm{Cr}$ Core}

Two compounds with the $\mathrm{Fe}=\mathrm{C}=\mathrm{Cr}$ core have been reported by the group of Beck and characterized by elemental analysis, IR, and UV spectroscopy. Thus, $(\mathrm{TPP}) \mathrm{Fe}=\mathrm{C}=\mathrm{Cr}(\mathrm{CO})_{5}$ and $(\mathrm{TAP}) \mathrm{Fe}=\mathrm{C}=\mathrm{Cr}(\mathrm{CO})_{5}$ (see Figure 41) were prepared upon reacting the related dichlorocarbene iron complexes $\left[(\mathrm{L}) \mathrm{Fe}=\mathrm{CCl}_{2}\right]$ with $\mathrm{Na}_{2}\left[\mathrm{Cr}(\mathrm{CO})_{5}\right]$ in THF (TAP = tetrakis(p-methoxyphenyl)porphyrinate) [121]. 


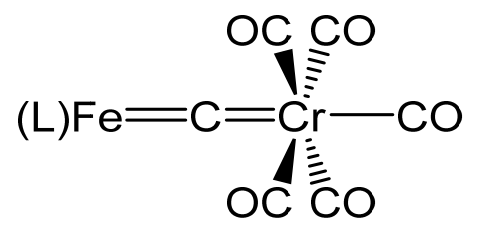

\section{(L) $\mathrm{Fe}=\mathrm{C}=\mathrm{Cr}(\mathrm{CO})_{5} ; \mathrm{L}=\mathrm{TPP}, \mathrm{TAP}$}

Figure 41. Structural representation of the $\mathrm{Fe}=\mathrm{C}=\mathrm{Cr}$ carbido complexes $(\mathrm{TPP}) \mathrm{Fe}=\mathrm{C}=\mathrm{Cr}(\mathrm{CO})_{5}$ and $(\mathrm{TAP}) \mathrm{Fe}=\mathrm{C}=\mathrm{Cr}(\mathrm{CO})_{5}$.

\section{Conclusions}

The experimental and theoretical research with regard transition metal complexes with carbone ligands [M]-CL $\mathrm{CL}_{2}$ and carbido complexes [M]-C has blossomed in the recent past and it can be foreseen that it will remain a very active area of organometallic chemistry in the future. The well-known family of transition metal complexes with C1-bonded carbon ligands that comprise alkyl $\left(\mathrm{CR}_{3}\right)$, carbene $\left(\mathrm{CR}_{2}\right)$, and carbyne $(\mathrm{CR})$ groups has been extended by carbones $\left(\mathrm{CL}_{2}\right)$ and carbido $(\mathrm{C})$ ligands. The summary of recent work, which is described in this review, indicates that carbone and carbido complexes are still largely terra incognita and that many new discoveries can be expected.

Author Contributions: Conceptualization and writing of the first draft, W.P. and G.F. Checking and partial visualization L.Z. and C.C. All authors have read and agreed to the published version of the manuscript.

Funding: The work at Marburg was financially supported by the Deutsche Forschungsgemeinschaft. L.Z. and G.F acknowledge the financial support from Nanjing Tech University (grant number 39837132 and 39837123), National Natural Science Foundation of China (Grant No. 21703099 and 21993044), Natural Science Foundation of Jiangsu Province for Youth (Grant No: BK20170964), and SICAM Fellowship from Jiangsu National Synergetic Innovation Center for Advanced Materials.

Conflicts of Interest: The authors declare no conflict of interest.

\section{References}

1. Frankland, E. Über die Isolierung der Organischen Radicale. Justus Liebigs Ann. Chem. 1849, 71, 171-213. [CrossRef]

2. Seyferth, D. Zinc Alkyls, Edward Frankland, and the Beginnings of Main-Group Organometallic Chemistry. Organomet. Chem. 2001, 20, 2940-2955. [CrossRef]

3. Fischer, E.O.M. A Zur Frage eines Wolfram-Carbonyl-Carben Komplexes. Angew. Chem. 1964, $76,645$. [CrossRef]

4. Fischer, E.O.; Kreis, G.; Kreiter, C.G.; Müller, J.; Huttner, G.; Lorenz, H. Trans-Halogeno[alkyl(aryl)carbyne] tetracarbonyl Complexes of Chromium, Molybdenum, and Tungsten-A New Class of Compounds Having a Transition Metal-Carbon Triple Bond. Angew. Chem. Int. Ed. 1973, 12, 564-565. [CrossRef]

5. Schrock, R.R. Alkylcarbene Complex of Tantalum by Intramolecular Alpha-Hydrogen Abstraction. J. Am. Chem. Soc. 1974, 96, 6796-6797. [CrossRef]

6. McLain, S.J.; Wood, C.D.; Messerle, L.W.; Schrock, R.R.; Hollander, F.J.; Youngs, W.J.; Churchill, M.R. Multiple Metal-Carbon Bonds. Thermally Stable Tantalum Alkylidyne Complexes and the Crystal Structure of $\mathrm{Ta}\left(\right.$. eta.5- $\left.\mathrm{C}_{5} \mathrm{Me}_{5}\right)(\mathrm{CPh})\left(\mathrm{PMe}_{3}\right)_{2}$ Cl. J. Am. Chem. Soc. 1978, 100, 5962-5964. [CrossRef]

7. Dewar, M.J.S. A Review of П Complex Theory. Bull. Soc. Chim. Fr. 1951, 18, C79.

8. Chatt, J.; Duncanson, L.A. 586. Olefin Co-Ordination Compounds. Part III. Infra-Red Spectra and Structure: Attempted Preparation of Acetylene Complexes. J. Chem. Soc. 1953, 1, 2939-2947. [CrossRef]

9. Vyboishchikov, S.F.; Frenking, G. Theoretical Studies of Organometallic Compounds, Part 29-Structure and Bonding of Low-Valent (Fischer-Type) and High-Valent (Schrock-Type) Transition Metal Carbene Complexes. Chem. Eur. J. 1998, 4, 1428-1438. [CrossRef]

10. Vyboishchikov, S.F.; Frenking, G. Structure and Bonding of Low-Valent (Fischer-Type) and High-Valent (Schrock-Type) Transition Metal Carbyne Complexes. Chem. Eur. J. 1998, 4, 1439-1448. [CrossRef]

11. Jerabek, P.; Schwerdtfeger, P.; Frenking, G. Dative and Electron-Sharing Bonding in Transition Metal Compounds. J. Comput. Chem. 2019, 40, 247-264. [CrossRef] [PubMed] 
12. Frenking, G.; Tonner, R. Divalent Carbon(0) Compounds. Pure Appl. Chem. 2009, 81, 597-614. [CrossRef]

13. Frenking, G.; Tonner, R.; Klein, S.; Takagi, N.; Shimizu, T.; Krapp, A.; Pandey, K.K.; Parameswaran, P. New Bonding Modes of Carbon and Heavier Group 14 Atoms Si-Pb. Chem. Soc. Rev. 2014, 43, 5106-5139. [CrossRef] [PubMed]

14. Frenking, G.; Hermann, M.; Andrada, D.M.; Holzmann, N. Donor-Acceptor Bonding in Novel Low-Coordinated Compounds of Boron and Group 14 Atoms C-Sn. Chem. Soc. Rev. 2016, 45, 1129-1144. [CrossRef]

15. Frenking, G.; Solà, M.; Vyboishchikov, S.F. Chemical bonding in transition metal carbene complexes. J. Organomet. Chem. 2005, 690, 6178-6204. [CrossRef]

16. Tonner, R.; Heydenrych, G.; Frenking, G. First and Second Proton Affinities of Carbon Bases. Chem. Phys. Chem. 2008, 9, 1474-1481. [CrossRef] [PubMed]

17. Jensen, P.; Johns, J.W.C. The Infrared Spectrum of Carbon Suboxide in the v6 Fundamental Region: Experimental Observation and Semirigid Bender Analysis. J. Mol. Spectrosc. 1986, 118, 248-266. [CrossRef]

18. Koput, J. An ab Initio Study on the Equilibrium Structure and CCC Bending Energy Levels of Carbon Suboxide. Chem. Phys. Lett. 2000, 320, 237-244. [CrossRef]

19. Tonner, R.; Frenking, G. Divalent Carbon(0) Chemistry, Part 1: Parent Compounds. Chem. Eur. J. 2008, 14, 3260-3272. [CrossRef]

20. Frenking, G. Dative Bonds in Main-Group Compounds: A Case for More Arrows! Angew. Chem. Int. Ed. 2014, 53, 6040-6046. [CrossRef]

21. Fustier-Boutignon, M.; Nebra, N.; Mézailles, N. Geminal Dianions Stabilized by Main Group Elements. Chem. Rev. 2019, 119, 855-8700. [CrossRef] [PubMed]

22. Petz, W.; Frenking, G. Carbodiphosphoranes and Related Ligands. Top. Organomet. Chem. 2010, 30, 49-92.

23. Petz, W. Addition Compounds between Carbones, $\mathrm{CL}_{2}$, and Main Group Lewis Acids: A New Glance at Old and New Compounds. Coord. Chem. Rev. 2015, 291, 1-27. [CrossRef]

24. Alcarazo, M. Synthesis, Structure, and Reactivity of Carbidiphosphoranes, Carbodicarbenes and Related Species. Struct. Bond. 2018, 177, 25-50.

25. Liu, S.; Chen, W.C.; Ong, T.G. Synthesis and Structure of Carbodicarbenes and Their Application in Catalysis. Struct. Bond. 2018, 177, 51-72.

26. Peters, J.C.; Odom, A.L.; Cummins, C.C. A Terminal Molybdenum Carbide Prepared by Methylidyne Deprotonation. Chem. Commun. 1997, 20, 1995-1996. [CrossRef]

27. Carlson, R.G.; Gile, M.A.; Heppert, J.A.; Mason, M.H.; Powell, D.R.; Velde, D.V.; Vilain, J.M. The Metathesis-Facilitated Synthesis of Terminal Ruthenium Carbide Complexes: A Unique Carbon Atom Transfer Reaction. J. Am. Chem. Soc. 2002, 124, 1580-1581. [CrossRef]

28. Krapp, A.; Pandey, K.K.; Frenking, G. Transition Metal-Carbon Complexes. A Theoretical Study. J. Am. Chem. Soc. 2007, 129, 7596-7610. [CrossRef]

29. Reinholdt, A.; Bendix, J. Platinum(ii) as an Assembly Point for Carbide and Nitride Ligands. Chem. Commun. 2019, 55, 8270-8273. [CrossRef]

30. Ramirez, F.; Desai, N.B.; Hansen, B.; McKelvie, N. Hexaphenylcarbodiphosphorane, $\left(\mathrm{C}_{6} \mathrm{H}_{5}\right)_{3} \mathrm{PCP}\left(\mathrm{C}_{6} \mathrm{H}_{5}\right)_{3}$. J. Am. Chem. Soc. 1961, 83, 3539-3540. [CrossRef]

31. Hussain, M.S.; Schmidbaur, H. Ein Gemischt Methyl/Phenyl-Substituiertes Carbodiphosphoran. Darstellung, Reaktionen und verwandte Verbindungen. Z. Nat. B 1976, 31, 721-726.

32. Kroll, A.; Steinert, H.; Scharf, L.T.; Scherpf, T.; Mallick, B.; Gessner, V.H. A Diamino-Substituted Carbodiphosphorane as Strong C-Donor and Weak N-Donor: Isolation of Monomeric Trigonal-Planar $\mathrm{L} \cdot \mathrm{ZnCl}_{2}$. Chem. Commun. 2020, 56, 8051-8054. [CrossRef] [PubMed]

33. Quinlivan, P.J.; Parkin, G. Flexibility of the Carbodiphosphorane, $\left(\mathrm{Ph}_{3} \mathrm{P}\right)_{2} \mathrm{C}$ : Structural Characterization of a Linear Form. Inorg. Chem. 2017, 56, 5493-5497. [CrossRef]

34. Böttger, S.; Gruber, M.; Münzer, J.E.; Bernard, G.M.; Kneusels, N.-J.H.; Poggel, C.; Klein, M.; Hampel, F.; Neumülöler, B.; Sundermeyer, J.; et al. Solvent-Induced Bond-Bending Isomerism in Hexaphenyl Carbodiphosphorane: Decisive Dispersion Interactions in the Solid State. Inorg. Chem. 2020, 59, 12054-12064.

35. Vincent, A.T.; Wheatley, P.J. Crystal Structure of Bis(triphenylphosphoranylidene)methane [hexaphenylcarbodiphosphorane, $\mathrm{Ph}_{3} \mathrm{P}: \mathrm{C}: \mathrm{PPh}_{3}$ ]. J. Chem. Soc. Dalton Trans. 1972, 5, 617-622. [CrossRef]

36. Schmidbaur, H.; Hasslberger, G.; Deschler, U.; Schubert, U.; Kappenstein, C.; Frank, A. Problem of the Structure of Carbodiphosphoranes, $\mathrm{R}_{3} \mathrm{PCPR}_{3}$-New Aspects. Angew. Chem. Int. Ed. 1979, 18, 408-409. [CrossRef] 
37. Schubert, U.; Kappenstein, C.; Milewskimahrla, B.; Schmidbaur, H. Molecular and Crystal-Structures of 2 Carbodiphosphoranes with P-C-P Bond Angles near 120-Degrees. Chem. Ber. Recl. 1981, 114, 3070-3078. [CrossRef]

38. Schmidbaur, H.; Costa, T.; Milewskimahrla, B.; Schubert, U. Ring-Strained Carbodiphosphoranes. Angew. Chem. Int. Ed. 1980, 19, 555-556. [CrossRef]

39. Petz, W.; Weller, F.; Uddin, J.; Frenking, G. Reaction of Carbodiphosphorane $\mathrm{Ph}_{3} \mathrm{P}=\mathrm{C}=\mathrm{PPh}_{3}$ with $\mathrm{Ni}(\mathrm{CO})_{4}$. Experimental and Theoretical Study of the Structures and Properties of $(\mathrm{CO})_{3} \mathrm{NiC}\left(\mathrm{PPh}_{3}\right)_{2}$ and $(\mathrm{CO})_{2} \mathrm{NiC}\left(\mathrm{PPh}_{3}\right)_{2}$. Organometallics 1999, 18, 619-626. [CrossRef]

40. Flosdorf, K.; Jiang, D.D.; Zhao, L.L.; Neumüller, B.; Frenking, G.; Kuzu, I. An Experimental and Theoretical Study of the Structures and Properties of CDPMe-Ni(CO $)_{3}$ and Ni-2(CO) $)_{4}\left(\mu^{2}-\mathrm{CO}\right)\left(\mu^{2}-\mathrm{CDPMe}\right)$. Eur. J. Inorg. Chem. 2019, 2019, 4546-4554. [CrossRef]

41. Petz, W.; Neumüller, B.; Klein, S.; Frenking, G. Syntheses and Crystal Structures of $\left[\mathrm{Hg}\left\{\mathrm{C}\left(\mathrm{PPh}_{3}\right)_{2}\right\}_{2}\right]\left[\mathrm{Hg}_{2} \mathrm{I}_{6}\right]$ and $\left[\mathrm{Cu}\left\{\mathrm{C}\left(\mathrm{PPh}_{3}\right)_{2}\right\}_{2}\right] \mathrm{I}$ and Comparative Theoretical Study of Carbene Complexes $\left[\mathrm{M}(\mathrm{NHC})_{2}\right]$ with Carbone Complexes $\left[\mathrm{M}\left\{\mathrm{C}(\mathrm{PH} 3)_{2}\right\}_{2}\right]\left(\mathrm{M}=\mathrm{Cu}^{+}, \mathrm{Ag}^{+}, \mathrm{Au}^{+}, \mathrm{Zn}^{2+}, \mathrm{Cd}^{2+}, \mathrm{Hg}^{2+}\right)$. Organometallics 2011, 30, 3330-3339. [CrossRef]

42. Petz, W.; Öxler, F.; Neumüller, B. Syntheses and Crystal Structures of Linear Coordinated Complexes of $\mathrm{Ag}^{+}$ with the Ligands $\mathrm{C}\left(\mathrm{PPh}_{3}\right)_{2}$ and $\left(\mathrm{HC}\left\{\mathrm{PPh}_{3}\right\}_{2}\right)^{+}$. J. Organomet. Chem. 2009, 694, 4094-4099. [CrossRef]

43. Sundermeyer, J.; Weber, K.; Peters, K.; von Schnering, H.G. Modeling Surface Reactivity of Metal Oxides: Synthesis and Structure of an Ionic Organorhenyl Perrhenate Formed by Ligand-Induced Dissociation of Covalent $\mathrm{Re}_{2} \mathrm{O}_{7}$. Organometallics 1994, 13, 2560-2562. [CrossRef]

44. Schmidbaur, H.; Zybill, C.E.; Müller, G.; Krüger, C. Coinage Metal Complexes of Hexaphenylcarbodiphosphorane-Organometallic Compounds with Coordination Number 2. Angew. Chem. Int. Ed. 1983, 22, 729-730. [CrossRef]

45. Zybill, C.; Mueller, G. Mononuclear Complexes of Copper(I) and Silver(I) Featuring the Metals Exclusively Bound to Carbon. Synthesis and Structure of (.eta.5-Pentamethylcyclopentadienyl)[(triphenylphosphonio) (triphenylphosphoranylidene)methyl]Copper(I). Organometallics 1987, 6, 2489-2494. [CrossRef]

46. Vicente, J.; Singhal, A.R.; Jones, P.G. New Ylide-, Alkynyl-, and Mixed Alkynyl/Ylide-Gold(I) Complexes. Organometallics 2002, 21, 5887-5900. [CrossRef]

47. Kaska, W.C.; Reichelderfer, R.F. The Interaction of Hexaphenylcarbodiphosphorane with Iridium Olefin Cations. Metalation of Coordinated Ligands. J. Organomet. Chem. 1974, 78, C47-C50. [CrossRef]

48. Münzer, J.E.; Kuzu, I.; Philipps-Universität Marburgdisabled, Marburg, Germany. Unpublished results. Private communication to WP.

49. Pranckevicius, C.; Iovan, D.A.; Stephan, D.W. Three and Four Coordinate Fe Carbodiphosphorane Complexes. Dalton Trans. 2016, 45, 16820-16825. [CrossRef]

50. Kneusels, N.J.H.; Münzer, J.E.; Flosdorf, K.; Jiang, D.; Neumüller, B.; Zhao, L.; Eichhöfer, A.; Frenking, G.; Kuzu, I. Double Donation in Trigonal Planar Iron-Carbodiphosphorane Complexes-A Aoncise Study on Their Spectroscopic and Electronic Properties. Dalton Trans. 2020, 49, 2537-2546. [CrossRef]

51. Su, W.; Pan, S.; Sun, X.; Wang, S.; Zhao, L.; Frenking, G.; Zhu, C. Double Dative Bond between Divalent Carbon(0) and Uranium. Nat. Commun. 2018, 9, 4997. [CrossRef]

52. Tonner, R.; Oexler, F.; Neumuller, B.; Petz, W.; Frenking, G. Carbodiphosphoranes: The Chemistry of Divalent Carbon(0). Angew. Chem. Int. Ed. 2006, 45, 8038-8042. [CrossRef] [PubMed]

53. Petz, W.; Neumüller, B. Reaction of $\mathrm{C}\left(\mathrm{PPh}_{3}\right)_{2}$ with $\mathrm{MI}_{2}$ Compounds $(\mathrm{M}=\mathrm{Zn}, \mathrm{Cd})$ - Formation and Crystal Structures of $\left[\mathrm{I}_{2} \mathrm{Zn}\left\{\mathrm{C}\left(\mathrm{PPh}_{3}\right)_{2}\right\}\right],\left[\left(\mathrm{I}_{2} \mathrm{Cd}\left\{\mathrm{C}\left(\mathrm{PPh}_{3}\right)_{2}\right\}\right)_{2}\right]$ and the Salt-Like Compounds $\left(\mathrm{HC}\left\{\mathrm{PPh}_{3}\right\}_{2}\right)\left[\mathrm{MI}_{3}(\mathrm{THF})\right]$ and $\left(\mathrm{HC}\left\{\mathrm{PPh}_{3}\right\}_{2}\right)_{2}[\mathrm{ZnI} 4]$. Eur. J. Inorg. Chem. 2011, 31, 4889-4895. [CrossRef]

54. Romeo, I.; Bardají, M.; Concepción Gimeno, M.; Laguna, M. Gold(I) Complexes Containing the Cationic Ylide Ligand Bis(methyldiphenylphosphonio)methylide. Polyhedron 2000, 19, 1837-1841. [CrossRef]

55. Bruce, A.E.; Gamble, A.S.; Tonker, T.L.; Templeton, J.L. Cationic Phosphonium Carbyne and Bis(phosphonium) Carbene Tungsten Complexes: [Tp'(OC) $\left.{ }_{2} \mathrm{WC}\left(\mathrm{PMe}_{3}\right) \mathrm{n}\right]\left[\mathrm{PF}_{6}\right](\mathrm{n}=1,2)$. Organometallics 1987, 6, 1350-1352. [CrossRef]

56. Schmidbaur, H.; Gasser, O. The Ambident Ligand Properties of Bis(trimethylphosphoranylidene)methan. Angew. Chem. Int. Ed. 1976, 15, 502-503. [CrossRef] 
57. Dorta, R.; Stevens, E.D.; Scott, N.M.; Costabile, C.; Cavallo, L.; Hoff, C.D.; Nolan, S.P. Steric and Electronic Properties of N-Heterocyclic Carbenes (NHC): A Detailed Study on Their Interaction with Ni(CO) 4 . J. Am. Chem. Soc. 2005, 127, 2485-2495. [CrossRef]

58. Pugh, D.; Wright, J.A.; Freeman, S.; Danopoulos, A.A. 'Pincer' Dicarbene Complexes of Some Early Transition Metals and Uranium. Dalton Trans. 2006, 6, 775-782. [CrossRef]

59. Gardner, B.M.; McMaster, J.; Liddle, S.T. Synthesis and Structure of a Dis-N-Heterocyclic Carbene Complex of Uranium Tetrachloride Exhibiting Short Cl ‥C Carbene Contacts. Dalton Trans. 2009, 35, 6924-6926. [CrossRef]

60. Doddi, A.; Gemel, C.; Seidel, R.W.; Winter, M.; Fischer, R.A. Coordination Complexes of TiX 4 (X = F, Cl) with a Bulky N-Heterocyclic Carbene: Syntheses, Characterization and Molecular Structures. Polyhedron 2013, 52, 1103-1108. [CrossRef]

61. Datt, M.S.; Nair, J.J.; Otto, S. Synthesis and Characterisation of Two Novel Rh(I) Carbene Complexes: Crystal Structure of $\left[\mathrm{Rh}(\mathrm{acac})(\mathrm{CO})\left(\mathrm{L}_{1}\right)\right]$. J. Organomet. Chem. 2005, 690, 3422-3426. [CrossRef]

62. Stallinger, S.; Reitsamer, C.; Schuh, W.; Kopacka, H.; Wurst, K.; Peringer, P. Novel Route to Carbodiphosphoranes Producing a New P,C,P Pincer Carbene Ligand. Chem. Commun. 2007, 510-512. [CrossRef]

63. Klein, M.; Demirel, N.; Schinabeck, A.; Yersin, H.; Sundermeyer, J. Cu(I) Complexes of Multidentate N,C,Nand P,C,P-Carbodiphosphorane Ligands and Their Photoluminescence. Molecules 2020, 25, 3990. [CrossRef]

64. Klein, M.; Xie, X.; Burghaus, O.; Sundermeyer, J. Synthesis and Characterization of a N,C,N-Carbodiphosphorane Pincer Ligand and Its Complexes. Organometallics 2019, 38, 3768-3777. [CrossRef]

65. Reitsamer, C.; Stallinger, S.; Schuh, W.; Kopacka, H.; Wurst, K.; Obendorf, D.; Peringer, P. Novel Access to Carbodiphosphoranes in the Coordination Sphere of Group 10 Metals: Template Synthesis and Protonation of PCP Pincer Carbodiphosphorane Complexes of C(dppm) 2. Dalton Trans. 2012, 41, 3503-3514. [CrossRef]

66. Maser, L.; Herritsch, J.; Langer, R. Carbodiphosphorane-Based Nickel Pincer Complexes and Their (de)Protonated Analogues: Dimerisation, Ligand Tautomers and Proton Affinities. Dalton Trans. 2018, 47, 10544-10552. [CrossRef] [PubMed]

67. Reitsamer, C.; Hackl, I.; Schuh, W.; Kopacka, H.; Wurst, K.; Peringer, P. Gold(I) and Gold(III) Complexes of the $\left[\mathrm{CH}(\mathrm{dppm})_{2}\right]^{+}$and C(dppm $)_{2}$ PCP Pincer Ligand Systems. J. Organomet. Chem. 2017, 830, 150-154. [CrossRef]

68. Su, W.; Pan, S.; Sun, X.; Zhao, L.; Frenking, G.; Zhu, C. Cerium-Carbon Dative Interactions Supported by Carbodiphosphorane. Dalton Trans. 2019, 48, 16108-16114. [CrossRef]

69. Kubo, K.; Jones, N.D.; Ferguson, M.J.; McDonald, R.; Cavell, R.G. Chelate and Pincer Carbene Complexes of Rhodium and Platinum Derived from Hexaphenylcarbodiphosphorane, $\mathrm{Ph}_{3} \mathrm{PCPPh}_{3}$. J. Am. Chem. Soc. 2005, 127, 5314-5315. [CrossRef] [PubMed]

70. Kubo, K.; Okitsu, H.; Miwa, H.; Kume, S.; Cavell, R.G.; Mizuta, T. Carbon(0)-Bridged Pt/Ag Dinuclear and Tetranuclear Complexes Based on a Cyclometalated Pincer Carbodiphosphorane Platform. Organometallics 2017, 36, 266-274. [CrossRef]

71. Petz, W.; Neumüller, B. New Platinum Complexes with Carbodiphosphorane as Pincer Ligand via Ortho Phenyl Metallation. Polyhedron 2011, 30, 1779-1784. [CrossRef]

72. Lin, G.; Jones, N.D.; Gossage, R.A.; McDonald, R.; Cavell, R.G. A Tris(carbene) Pincer Complex: Monomeric Platinum Carbonyl with Three Bound Carbene Centers. Angew. Chem. Int. Ed. 2003, 42, 4054-4057. [CrossRef]

73. Marrot, S.; Kato, T.; Gornitzka, H.; Baceiredo, A. Cyclic Carbodiphosphoranes: Strongly Nucleophilic $\sigma$-Donor Ligands. Angew. Chem. Int. Ed. 2006, 45, 2598-2601. [CrossRef] [PubMed]

74. Corberán, R.; Marrot, S.; Dellus, N.; Merceron-Saffon, N.; Kato, T.; Peris, E.; Baceiredo, A. First Cyclic Carbodiphosphoranes of Copper(I) and Gold(I) and Their Application in the Catalytic Cleavage of X-H Bonds (X = N and O). Organometallics 2009, 28, 326-330. [CrossRef]

75. Yogendra, S.; Schulz, S.; Hennersdorf, F.; Kumar, S.; Fischer, R.; Weigand, J.J. Reductive Ring Opening of a Cyclo-Tri(phosphonio)methanide Dication to a Phosphanylcarbodiphosphorane: In Situ UV-Vis Spectroelectrochemistry and Gold Coordination. Organometallics 2018, 37, 748-754. [CrossRef]

76. Alcarazo, M.; Radkowski, K.; Mehler, G.; Goddard, R.; Fürstner, A. Chiral Heterobimetallic Complexes of Carbodiphosphoranes and Phosphinidene-Carbene Adducts. Chem. Commun. 2013, 49, 3140-3142. [CrossRef] [PubMed] 
77. Petz, W.; Kutschera, C.; Neumüller, B. Reaction of the Carbodiphosphorane $\mathrm{Ph}_{3} \mathrm{PCPPh}$ with Platinum(II) and -(0) Compounds: Platinum Induced Activation of C-H Bonds. Organometallics 2005, 24, 5038-5043. [CrossRef]

78. Baldwin, J.C.; Kaska, W.C. The Interaction of Hexaphenylcarbodiphosphorane with the Trimethylplatinum(IV) Cation. Inorg. Chem. 1979, 18, 686-691. [CrossRef]

79. Melaimi, M.; Parameswaran, P.; Donnadieu, B.; Frenking, G.; Bertrand, G. Synthesis and Ligand Properties of a Persistent, All-Carbon Four-Membered-Ring Allene. Angew. Chem. Int. Ed. 2009, 48, 4792-4795. [CrossRef]

80. Hackl, L.; Petrov, A.R.; Bannenberg, T.; Freytag, M.; Jones, P.G.; Tamm, M. Dimerisation of Dipiperidinoacetylene: Convenient Access to Tetraamino-1,3-Cyclobutadiene and Tetraamino-1,2-Cyclobutadiene Metal Complexes. Chem. Eur. J. 2019, 25, 16148-16155. [CrossRef]

81. Pranckevicius, C.; Liu, L.; Bertrand, G.; Stephan, D.W. Synthesis of a Carbodicyclopropenylidene: A Carbodicarbene Based Solely on Carbon. Angew. Chem. Int. Ed. 2016, 55, 5536-5540. [CrossRef]

82. Tonner, R.; Frenking, G. C(NHC) $)_{2}$ : Divalent Carbon(0) Compounds with N-Heterocyclic Carbene Ligands-Theoretical Evidence for a Class of Molecules with Promising Chemical Properties. Angew. Chem. Int. Ed. 2007, 46, 8695-8698. [CrossRef] [PubMed]

83. Dyker, C.A.; Lavallo, V.; Donnadieu, B.; Bertrand, G. Synthesis of an Extremely Bent Acyclic Allene (A “Carbodicarbene”): A Strong Donor Ligand. Angew. Chem. Int. Ed. 2008, 47, 3206-3209. [CrossRef]

84. Hsu, Y.C.; Shen, J.S.; Lin, B.C.; Chen, W.C.; Chan, Y.T.; Ching, W.M.; Yap, G.P.A.; Hsu, C.P.; Ong, T.G. Synthesis and Isolation of an Acyclic Tridentate Bis(pyridine)carbodicarbene and Studies on Its Structural Implications and Reactivities. Angew. Chem. Int. Ed. 2015, 54, 2420-2424. [CrossRef]

85. Chen, W.C.; Hsu, Y.C.; Lee, C.Y.; Yap, G.P.A.; Ong, T.G. Synthetic Modification of Acyclic Bent Allenes (Carbodicarbenes) and Further Studies on Their Structural Implications and Reactivities. Organometallics 2013, 32, 2435-2442. [CrossRef]

86. Liberman-Martin, A.L.; Grubbs, R.H. Ruthenium Olefin Metathesis Catalysts Featuring a Labile Carbodicarbene Ligand. Organometallics 2017, 36, 4091-4094. [CrossRef]

87. Chan, S.C.; Gupta, P.; Engelmann, X.; Ang, Z.Z.; Ganguly, R.; Bill, E.; Ray, K.; Ye, S.F.; England, J. Observation of Carbodicarbene Ligand Redox Noninnocence in Highly Oxidized Iron Complexes. Angew. Chem. Int. Ed. 2018, 57, 15717-15722. [CrossRef]

88. Chen, W.C.; Shih, W.C.; Jurca, T.; Zhao, L.L.; Andrada, D.M.; Peng, C.J.; Chang, C.C.; Liu, S.K.; Wang, Y.P.; Wen, Y.S.; et al. Carbodicarbenes: Unexpected $\pi$-Accepting Ability during Reactivity with Small Molecules. J. Am. Chem. Soc. 2017, 139, 12830-12836. [CrossRef] [PubMed]

89. Shih, W.C.; Chiang, Y.T.; Wang, Q.; Wu, M.C.; Yap, G.P.A.; Zhao, L.; Ong, T.G. Invisible Chelating Effect Exhibited between Carbodicarbene and Phosphine through $\pi-\pi$ Interaction and Implication in the Cross-Coupling Reaction. Organometallics 2017, 36, 4287-4297. [CrossRef]

90. Chen, W.C.; Shen, J.S.; Jurca, T.; Peng, C.J.; Lin, Y.H.; Wang, Y.P.; Shih, W.C.; Yap, G.P.A.; Ong, T.G. Expanding the Ligand Framework Diversity of Carbodicarbenes and Direct Detection of Boron Activation in the Methylation of Amines with $\mathrm{CO}_{2}$. Angew. Chem. Int. Ed. 2015, 54, 15207-15212. [CrossRef] [PubMed]

91. Ruiz, D.A.; Melaimi, M.; Bertrand, G. Carbodicarbenes, Carbon(0) Derivatives, Can Dimerize. Chem. Asian J. 2013, 8, 2940-2942. [CrossRef]

92. Pranckevicius, C.; Fan, L.; Stephan, D.W. Cyclic Bent Allene Hydrido-Carbonyl Complexes of Ruthenium: Highly Active Catalysts for Hydrogenation of Olefins. J. Am. Chem. Soc. 2015, 137, 5582-5589. [CrossRef]

93. Goldfogel, M.J.; Roberts, C.C.; Meek, S.J. Intermolecular Hydroamination of 1,3-Dienes Catalyzed by Bis(phosphine)carbodicarbene-Rhodium Complexes. J. Am. Chem. Soc. 2014, 136, 6227-6230. [CrossRef]

94. Roberts, C.C.; Matías, D.M.; Goldfogel, M.J.; Meek, S.J. Lewis Acid Activation of Carbodicarbene Catalysts for Rh-Catalyzed Hydroarylation of Dienes. J. Am. Chem. Soc. 2015, 137, 6488-6491. [CrossRef]

95. Fürstner, A.; Alcarazo, M.; Goddard, R.; Lehmann, C.W. Coordination Chemistry of Ene-1,1-diamines and a Prototype "Carbodicarbene". Angew. Chem. Int. Ed. 2008, 47, 3210-3214. [CrossRef] [PubMed]

96. Paoletti, A.M.; Pennesi, G.; Rossi, G.; Ercolani, C. A New Approach to Cofacially Assembled Partially Oxidized Metal Phthalocyanine Low Dimensional Solids: Synthesis, Structure, and Electrical Conductivity Properties of the Fe(IV) Containing Species $\left[(\mathrm{PcFe})_{2} \mathrm{C}\right]\left(\mathrm{l}_{3}\right)_{0.66}$ Obtained by $\mathrm{I}_{2}$ Doping of (m-Carbido)bis[phthalocyaninatoiron(IV)]. Inorg. Chem. 1995, 34, 4780-4784.

97. Burzlaff, H.; Voll, U.; Bestmann, H.J. Die Kristall- und Molekülstruktur des (2,2-Diäthoxyvinyliden) -triphenylphosphorans. Chem. Ber. 1974, 107, 1949-1956. [CrossRef] 
98. Alcarazo, M.; Lehmann, C.W.; Anoop, A.; Thiel, W.; Furstner, A. Coordination Chemistry at Carbon. Nat. Chem. 2009, 1, 295-301. [CrossRef]

99. Troadec, T.; Wasano, T.; Lenk, R.; Baceiredo, A.; Saffon-Merceron, N.; Hashizume, D.; Saito, Y.; Nakata, N.; Branchadell, V.; Kato, T. Donor-Stabilized Silylene/Phosphine-Supported Carbon(0) Center with High Electron Density. Angew. Chem. Int. Ed. 2017, 56, 6891-6895. [CrossRef] [PubMed]

100. Morosaki, T.; Wang, W.W.; Nagase, S.; Fujii, T. Synthesis, Structure, and Reactivities of Iminosulfane- and Phosphane-Stabilized Carbones Exhibiting Four-Electron Donor Ability. Chem. Eur. J. 2015, 21, 15405-15411. [CrossRef] [PubMed]

101. Pascual, S.; Asay, M.; Illa, O.; Kato, T.; Bertrand, G.; Saffon-Merceron, N.; Branchadell, V.; Baceiredo, A. Synthesis of a Mixed Phosphonium-Sulfonium Bisylide $\mathrm{R}_{3} \mathrm{P}=\mathrm{C}=\mathrm{SR}_{2}$. Angew. Chem. Int. Ed. 2007, 46, 9078-9080. [CrossRef]

102. Morosaki, T.; Iijima, R.; Suzuki, T.; Wang, W.W.; Nagase, S.; Fujii, T. Synthesis, Electronic Structure, and Reactivities of Two-Sulfur-Stabilized Carbones Exhibiting Four-Electron Donor Ability. Chem. Eur. J. 2017, 23, 8694-8702. [CrossRef]

103. Morosaki, T.; Suzuki, T.; Wang, W.W.; Nagase, S.; Fujii, T. Syntheses, Structures, and Reactivities of Two Chalcogen-Stabilized Carbones. Angew. Chem. Int. Ed. 2014, 53, 9569-9571. [CrossRef]

104. Fujii, T.; Ikeda, T.; Mikami, T.; Suzuki, T.; Yoshimura, T. Synthesis and Structure of $(\mathrm{MeN}) \mathrm{Ph}_{2} \mathrm{~S}=\mathrm{C}=\mathrm{SPh}_{2}(\mathrm{NMe})$. Angew. Chem. Int. Ed. 2002, 41, 2576-2578. [CrossRef]

105. Morosaki, T.; Suzuki, T.; Fujii, T. Syntheses and Structural Characterization of Mono-, Di-, and Tetranuclear Silver Carbone Complexes. Organometallics 2016, 35, 2715-2721. [CrossRef]

106. Chen, Y.; Petz, W.; Frenking, G. Is It Possible to Synthesize a Low-Valent Transition Metal Complex with a Neutral Carbon Atom as Terminal Ligand? A Theoretical Study of (CO) ${ }_{4}$ FeC. Organometallics 2000, 19, 2698-2706. [CrossRef]

107. Zhao, L.; von Hopffgarten, M.; Andrada, D.M.; Frenking, G. Energy Decomposition Analysis. Wires Comput. Mol. Sci. 2018, 8, e1345. [CrossRef]

108. Takemoto, S.; Matsuzaka, H. Recent Advances in the Chemistry of Ruthenium Carbido Complexes. Coord. Chem. Rev. 2012, 256, 574-588. [CrossRef]

109. Hejl, A.; Trnka, T.M.; Day, M.W.; Grubbs, R.H. Terminal Ruthenium Carbido Complexes as $\sigma$-Donor Ligands. Chem. Commun. 2002, 21, 2524-2525. [CrossRef]

110. Caskey, S.R.; Stewart, M.H.; Kivela, J.E.; Sootsman, J.R.; Johnson, M.J.A.; Kampf, J.W. Two Generalizable Routes to Terminal Carbido Complexes. J. Am. Chem. Soc. 2005, 127, 16750-16751. [CrossRef]

111. Reinholdt, A.; Bendix, J. Weakening of Carbide-Platinum Bonds as a Probe for Ligand Donor Strengths. Inorg. Chem. 2017, 56, 12492-12497. [CrossRef]

112. Reinholdt, A.; Vibenholt, J.E.; Morsing, T.J.; Schau-Magnussen, M.; Reeler, N.E.A.; Bendix, J. Carbide Complexes as $\pi$-Acceptor Ligands. Chem. Sci. 2015, 6, 5815-5823. [CrossRef]

113. Reinholdt, A.; Herbst, K.; Bendix, J. Delivering Carbide Ligands to Sulfide-Rich Clusters. Chem. Commun. 2016, 52, 2015-2018. [CrossRef] [PubMed]

114. Hong, S.H.; Day, M.W.; Grupps, R.H. Decomposition of a Key Intermediate in Ruthenium-Catalyzed Olefin Metatesis Reactions. J. Am. Chem. Soc. 2004, 126, 7414-7415. [CrossRef] [PubMed]

115. Morsing, T.J.; Reinholdt, A.; Sauer, S.P.A.; Bendix, J. Ligand Sphere Conversions in Terminal Carbide Complexes. Organometallics 2016, 35, 100-105. [CrossRef]

116. Stewart, M.H.; Johnson, M.J.A.; Kampf, J.W. Terminal Carbido Complexes of Osmium: Synthesis, Structure, and Reactivity Comparison to the Ruthenium Analogues. Organometallics 2007, 26, 5102-5110. [CrossRef]

117. Etienne, M.; White, P.S.; Templeton, J.L. An Agostic.mu.-Methyne Molybdenum-Iron Complex from Protonation of a.mu.-Carbide Precursor, $\mathrm{Tp}^{\prime}(\mathrm{CO})_{2} \mathrm{Mo} . t p l b o n d . \mathrm{CFe}(\mathrm{CO})_{2} \mathrm{Cp}$. J. Am. Chem. Soc. 1991, 113, 2324-2325. [CrossRef]

118. Cordiner, L.R.; Hill, A.F.; Wagler, J. Facil Generation of Lithiocarbyne Complexes; $\left[\mathrm{M}(\equiv \mathrm{CLi})(\mathrm{CO})_{2}\right.$ $\left.\left\{\mathrm{HB}\left(\mathrm{pzMe}_{2}\right)_{3}\right\}\right](\mathrm{M}=\mathrm{Mo}, \mathrm{W} ; \mathrm{pz}=$ Pyrazol-1-yl). Organometallics 2008, 27, 5177-5179. [CrossRef]

119. Cade, I.A.; Hill, A.F.; McQueen, C.M.A. Iridium-Molybdenum Carbido Complex via C-Se Activation of a Selenocarbonyl Ligand: $\left(\mu-\mathrm{Se}_{2}\right)\left[\operatorname{Ir}_{2}\left\{\mathrm{C} \equiv \mathrm{Mo}(\mathrm{CO})_{2}\left(\mathrm{Tp}^{*}\right)\right\}_{2}(\mathrm{CO})_{2}\left(\mathrm{PPh}_{3}\right)_{2}\right]\left(\mathrm{Tp}^{*}=\right.$ Hydrotris (dimethylpyrazolyl)borate). Organometallics 2009, 28, 6639-6641. [CrossRef] 
120. Colebatch, A.L.; Cordiner, R.L.; Hill, A.F.; Nguyen, K.T.H.D.; Shang, R.; Willis, A.C. A Bis-Carbyne (Ethanediylidyne) Complex via the Catalytic Demercuration of a Mercury Bis(carbido) Complex. Organometallics 2009, 28, 4394-4399. [CrossRef]

121. Knauer, W.; Beck, W. Carbide Bridged Complexes $\left[\mathrm{HB}(\mathrm{pz})_{3}(\mathrm{OC})_{2} \mathrm{Mo}=\mathrm{C}-\mathrm{Pt}\left(\mathrm{PPh}_{3}\right)_{2} \mathrm{Br}\right],[(\mathrm{TPP}) \mathrm{Fe}=\mathrm{C}-\mathrm{M}$ $\left.\left.\left.(\mathrm{CO})_{4}-\mathrm{M}(\mathrm{CO})_{5}\right](\mathrm{M}=\mathrm{Mn}, \mathrm{Re}),\left[(\mathrm{TPP}) \mathrm{Fe}=\mathrm{C}=\mathrm{Cr}(\mathrm{CO})_{5}\right], \mathrm{TPP}\right) \mathrm{Fe}=\mathrm{C}=\mathrm{Fe}(\mathrm{CO})_{4}\right]$ (pz- 3,5-dimethylpyrazol-1-yl; TPP Tetraphenylporphyrinate) from Halogeno-Carbyne and -Carbene Complexes. Z. Anorg. Allg. Chem. 2008, 634, 2241-2245. [CrossRef]

122. Borren, E.S.; Hill, A.F.; Shang, R.; Sharma, M.; Willis, A.C. A Golden Ring: Molecular Gold Carbido Complexes. J. Am. Chem. Soc. 2013, 135, 4942-4945. [CrossRef]

123. Buss, J.A.; Agapie, T. Mechanism of Molybdenum-Mediated Carbon Monoxide Deoxygenation and Coupling: Mono- and Dicarbyne Complexes Precede C-O Bond Cleavage and C-C Bond Formation. J. Am. Chem. Soc. 2016, 138, 16466-16477. [CrossRef] [PubMed]

124. Hill, A.F.; Sharma, M.; Willis, A.C. Heterodinuclear Bridging Carbido and Phosphoniocarbyne Complexes. Organometallics 2012, 31, 2538-2542. [CrossRef]

125. Frogley, B.J.; Hill, A.F. Tungsten-Platinum $\mu$-Carbido and $\mu$-Methylidyne Complexes. Chem. Commun. 2019, 55, 12400-12403. [CrossRef] [PubMed]

126. Agapie, T.; Diaconescu, P.L.; Cummins, C.C. Methine (CH) Transfer via a Chlorine Atom Abstraction/Benzene-Elimination Strategy: Molybdenum Methylidyne Synthesis and Elaboration to a Phosphaisocyanide Complex. J. Am. Chem. Soc. 2002, 124, 2412-2413. [CrossRef] [PubMed]

127. Latesky, S.L.; Selegue, J.P. Preparation and Structure of $\left.\left[\left(\mathrm{Me}_{3} \mathrm{CO}\right)_{3} \text { W.tplbond.C-Ru(CO) }\right)_{2}(\mathrm{Cp})\right]$, a Heteronuclear,.mu.2-Carbide Complex. J. Am. Chem. Soc. 1987, 109, 4731-4733. [CrossRef]

128. Mansuy, D.; Lecomte, J.P.; Chottard, J.C.; Bartoli, J.F. Formation of a Complex with a Carbide Bridge between Two Iron Atoms from the Reaction of (Tetraphenylporphyrin)iron(II) with Carbon Tetraiodide. Inorg. Chem. 1981, 20, 3119-3121. [CrossRef]

129. Battioni, J.-P.; Dupre, D.; Mansuy, D. Reactions du Trichloromethyl-Trimethyl-Silane avec des Ferrotetra-Aryl-Porphyrines. J. Organometal. Chem. 1981, 414, 303-309. [CrossRef]

130. Galich, L.; Kienast, A.; Hückstädt, H.; Homborg, H. Syntheses, Spectroscopical Properties, and Crystal Structures of Binuclear Homo- and Heteroleptic $\mu$-Carbido Complexes of Iron(IV) with Phthalocyaninate and Tetraphenylporphyrinate Ligands. Z. Anorg. Allg. Chem. 1998, 624, 1235-1242. [CrossRef]

131. Goedken, V.L.; Deakin, M.R.; Bottomley, L.A. Molecular Stereochemistry of a Carbon-Bridged Metalloporphyrin: $\mu$-Carbido-Bid(5,10,15,20-tetraphenylporphinatoiron). J. Chem. Soc. Chem. Commun. 1982, 11, 607-608. [CrossRef]

132. Kienast, A.; Galich, L.; Murray, K.S.; Moubaraki, B.; Lazarev, G.; Cashion, J.D.; Homborg, H. M-Carbido Dipophyrinates and Diphthalocyaninates of Iron and Ruthenium. J. Porphyr. Phthalocyanines 1997, 1, 141-157. [CrossRef]

133. Kienast, A.; Bruhn, C.; Homborg, H. Synthesis, Properties, and Crystal Structure of $\mu$-Carbidodi (pyridinephthalocyaninato(2-)Iron(IV)) and -Ruthenium(IV). Z. Anorg. Allg. Chem. 1997, 623, 967-972. [CrossRef]

134. Rossi, G.; Goedken, V.L.; Ercolani, C. $\mu$-Carbido-Bridged Iron Phthalocyanine Dimers: Synthesis and Characterization. J. Chem. Soc. Chem. Commun. 1988, 1, 46-47. [CrossRef]

135. Kienast, A.; Homborg, H. Synthese und Eigenschaften von Bis(tetra(n-butyl)ammonium)-1carbidodi(halogenophthalocyaninato(2-)ferraten(IV)); Kristallstruktur von Bis(tetra(n-butyl)ammonium)- $\mu$ -carbidodi(fluorophthalocyaninato(2-)ferrat(IV))-Trihydrat. Z. Anorg. Chem. 1998, 624, 107-112. [CrossRef]

136. Ercolani, C.; Gardini, M.; Goedken, V.L.; Pennesi, G.; Rossi, G.; Russo, U.; Zanonato, P. High-Valent Iron Phthalocyanine Five- and Six-Coordinated $\mu$-Carbido Dimers. Inorg. Chem. 1989, 28, 3097-3099. [CrossRef]

137. Ahrens, T.; Schmiedecke, B.; Braun, T.; Herrmann, R.; Laubenstein, R. Activation of $\mathrm{CS}_{2}$ and COS at a Rhodium(I) Germyl Complex: Generation of CS and Carbido Complexes. Eur. J. Inorg. Chem. 2017, 3, 713-722. [CrossRef]

138. Kalläne, S.I.; Braun, T.; Teltewskoi, M.; Braun, B.; Herrmann, R.; Laubenstein, R. Remarkable Reactivity of a Rhodium(i) Boryl Complex Towards $\mathrm{CO}_{2}$ and $\mathrm{CS}_{2}$ : Isolation of a Carbido Complex. Chem. Commun. 2015, 51, 14613-14616. [CrossRef]

139. Barnett, H.J.; Burt, L.K.; Hill, A.F. Simple Generation of a Dirhodium $\mu$-Carbido Complex via Thiocarbonyl Reduction. Dalton Trans. 2018, 47, 9570-9574. [CrossRef] 
140. Solari, E.; Antonijevic, S.; Gauthier, S.; Scopelliti, R.; Severin, K. Formation of a Ruthenium mu-Carbide Complex with Acetylene as the Crbon Source. Eur. J. Inorg. Chem. 2007, 3, 367-371. [CrossRef]

141. Young, R.D.; Hill, A.F.; Cavigliasso, G.E.; Stranger, R. $\left[(\mu-C)\left\{\operatorname{Re}(C O)_{2}\left(\eta-C_{5} H_{5}\right)\right\}_{2}\right]$ : A Surprisingly Simple Bimetallic Carbido Complex. Angew. Chem. Int. Ed. 2013, 52, 3699-3702. [CrossRef]

142. Miller, R.L.; Wolczanski, P.T.; Rheingold, A.L. Carbide Formation via Carbon Monoxide Dissociation Across a W $\equiv W$ Bond. J. Am. Chem. Soc. 1993, 115, 10422-10423. [CrossRef]

143. Beck, W.; Knauer, W.; Robl, C. Synthesis and Structure of the Novel $\mu$-Carbido Complex $[(\mathrm{TPP}) \mathrm{Fe}=\mathrm{C}=\mathrm{Re}$ $(\mathrm{CO})_{4} \operatorname{Re}(\mathrm{CO})_{5}$ ]. Angew. Chem. Int. Ed. 1990, 29, 318-320. [CrossRef]

Publisher's Note: MDPI stays neutral with regard to jurisdictional claims in published maps and institutional affiliations.

(C) 2020 by the authors. Licensee MDPI, Basel, Switzerland. This article is an open access article distributed under the terms and conditions of the Creative Commons Attribution (CC BY) license (http://creativecommons.org/licenses/by/4.0/). 